Portland State University

PDXScholar

Summer 8-26-2015

\title{
The Forgotten Front: Gender, Labor, and Politics in \\ Camas, Washington, and the Northwest Paper Industry, 1913-1918
}

Bradley Dale Richardson

Portland State University

Follow this and additional works at: https://pdxscholar.library.pdx.edu/open_access_etds

Part of the Labor History Commons

Let us know how access to this document benefits you.

Recommended Citation

Richardson, Bradley Dale, "The Forgotten Front: Gender, Labor, and Politics in Camas, Washington, and the Northwest Paper Industry, 1913-1918" (2015). Dissertations and Theses. Paper 2534.

https://doi.org/10.15760/etd.2531

This Thesis is brought to you for free and open access. It has been accepted for inclusion in Dissertations and Theses by an authorized administrator of PDXScholar. Please contact us if we can make this document more accessible: pdxscholar@pdx.edu. 
The Forgotten Front: Gender, Labor, and Politics in Camas, Washington, and the Northwest Paper Industry, 1913-1918

by

Bradley Dale Richardson

A Thesis submitted in partial fulfillment of the requirements for the degree of

\author{
Masters of Arts \\ in \\ History \\ Thesis Committee: \\ Patricia A. Schechter, Chair \\ Tim Garrison \\ Marc Rodriguez \\ Laurie Mercier
}

Portland State University

2015 


\begin{abstract}
Southwest Washington labor history has received little examination by scholars. Focusing mainly on Seattle, Everett, Centralia, and Spokane, historians view Southwest Washington, a traditionally conservative community, to be of little importance in the state's overall historical narrative. This thesis corrects that assumption and the omission of Southwest Washington. The failure of the unionization effort in Camas impacted organization in Pacific Northwest paper mills for nearly a decade. Although workers failed to sustain their union, the events in Camas between 1913 and 1918 present an excellent new laboratory and case study to explore the intersection of gender, labor, and politics. Despite rough edges and sometimes missing voices within the extant record of the time, this thesis suggests the potential for historians to dig deep into the archives, produce original scholarship, and tell a forgotten story.
\end{abstract}

This work is also ambitious, striving to examine the role gender, labor, and leftists' politics played in the paper mill city of Camas and Washington State. Chapter one examines the first-ever strike of forty women in the Camas bag factory. Chapter two explores the organization of the mills' first union. Chapter three accounts for the rise and fall of the town's only Socialist mayor. Each of these chapters alone could be the topic of a single study and each involves a particular segment of historical scholarship. The chapters are layered and refer to each other, with layers of context added in each one.

The themes of this thesis also orbit around a fight over meaning and historical memory. My research shows that during the tumultuous social, economic, and political events from 1913 to 1918 there was an active erasure and forgetting of people and events. These silencings amid a major uproar in a "labor village" partly accounts for the thinness 
of the archives and the haunted, subjugated quality of the memory of working peoples' activism in Camas. I suggest that labor, management, and the political establishment were all invested in a particular mythos of Camas as a "labor village." Camas was, and is, a company town and "labor village." Camas had a face-to-face quality to its social relations and members of the community felt pressure to maintain this quality, sometimes in opposition to "outside" voices. This scenario put special demands on the people involved with organizing and activism, as they functioned without the big city anonymity of Seattle or Portland. The Camas story is shorter, more concentrated, and more intimate than the stories of these large urban centers. The brief moment of change around the war strained the fraternal bonds of the town. The pain and injury of this strain in Camas were rhetorically covered and hidden. Most of the residents either never spoke of what happened or willed themselves to forget. The memory and knowledge of the events remain to this day imprisoned within their minds and town. This work intends to, after nearly a hundred years, bring back the memories and question the story told about Camas and about ourselves. 


\section{Acknowledgements}

Finishing this thesis has been the most difficult and enriching educational experience of my life. Without the support of family, faculty, and friends, this work would have remained an unfinished manuscript.

I first want to thank my amazing wife. She alone supported our family through this endeavor. Working extra shifts to allow me to follow my passion. She has shown the deepest love and compassion for me through her constant encouragement. She has taken my late nights, early mornings, and moments of weakness with stride. In league with my wife, my moms, Maelene Jacobs and Diane Gibson, never doubted my ability to reach this goal and gave their time to watch my daughters so I could work.

I did not reserve all of my unpleasantness for my wife. Patricia Schechter, my advisor, received her fair share. Draft after draft, Patricia had to push me to be a better historian and writer. Her honesty and instruction encouraged me to work harder and constantly improve. The conversations about my work enriched not only this thesis but also my efforts as a public historian. The impact she has and will continue to have on my career is indescribable.

There were others before Patricia, though. The guidance of Sue Peabody during my time as an undergraduate was priceless. She identified my strengths and directed me toward the perfect career path. Laurie Mercier also shaped the historian that I have become. She saw me through my first original research project and has remained a mentor to me ever since. Tim Garrison also had to endure my antics and during several courses, in class and one-on-one, has always taken me to task when necessary. For that I want to thank him. 
Many gave time and attention to this effort, but Jo and Steve Zimmerman went above and beyond. Only knowing me as the goofy museum walking tour guide, their generosity and cheerleading gave me both the necessary breathing room and energy to complete this thesis. I will never forget their kindness and only hope to some day repay a little of what they've given to me.

Last, but not least, I want to thank my co-workers at the Clark County Historical Museum. Kris Wells, Susan Tissot, Katie Anderson, Karen Washabaugh, and Nubez Jordan have all given time and support to make this a reality. Furthermore, the volunteers at the museum had to endure my constant stress during this process, for that reason, I want to thank Jan Anderson, Gail Becker, Sandy Hayslip, Susan and Jim Jacobs, Gayle Mitchell, Judith Montes-Guzman, and many others. It has taken a village to raise this historian and I thank you all for your contributions. 


\section{Table of Contents}

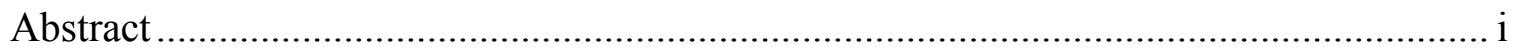

Acknowledgements ............................................................................................

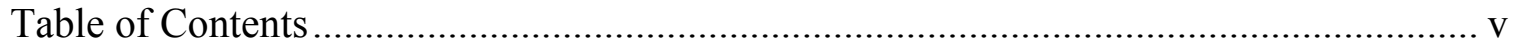

Introduction:

A Monumental Moment for Camas ................................................................................. 1

\section{Chapter I:}

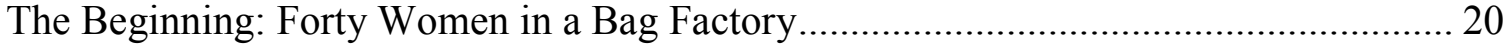

Chapter II:

Tempest of Organization: The Strikes of 1916-1918 .................................................. 51

Chapter III:

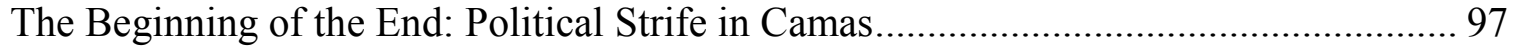

Conclusion:

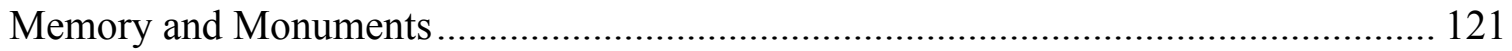

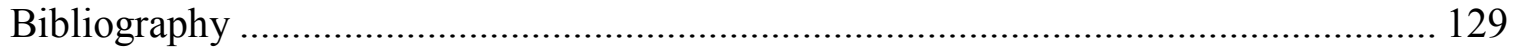




\section{Introduction:}

\section{A Monumental Moment for Camas}

"Before the council meeting about 200 Camas citizens marched up Fourth Street carrying torches and bearing a large American flag, and behind the procession four pallbearers carried a black coffin, the significance of which was the last of the 'Camas Bolsheviki'."1 This striking imagery crafted by The Oregonian newspaper on March 14, 1918, described the public celebration resulting from the recall of Camas mayor Oliver T. Clark. A steadfast member of the Washington State Socialist Party, Clark was elected mayor in 1916. However, a protracted labor struggle in the city turned public sentiment against Clark and other Socialist leaders. They became symbols of the disunity and strife plaguing the community during a time of war. Though such a turnabout resonates with the squelching of labor and left protest in other industrial centers in the United States at this time, there is more than meets the eye-or the archive-in the Camas story. The reported celebration was a contested account — part fact, part fiction—whose irresolution was indicative of the seething tensions over gender, labor, and politics in the Pacific Northwest.

Conflict over the meaning of Clark's recall points to the fractious undercurrents beneath the electoral sweep. The foremost labor publication in the area, the Oregon Labor Press, disputed The Oregonian's account about the end of the Socialist administration implied by the word "Bolsheviki". ${ }^{2}$ The Oregon Labor Press called The Oregonian's report a fabrication, proclaiming, "there is nothing in the article to answer, as practically every statement made is an absolute falsehood or a wild distortion of the

1 "Clean up Campaign Over," Oregonian (Portland, OR), March 14, 1918.

2 "Camas Council Appoints W.E. Farr to Office," Oregonian (Portland, OR), March 14, 1918. 
truth. ${ }^{3}$ Ideologically at odds, these publications often accused the other of printing lies, a situation that escalated when Mayor Clark refused to use law enforcement to quell a series of strikes at the Crown Willamette Paper Mill in Camas. Nevertheless, both reports contained seeds of truth. The two newspapers' war of words over the course of the 11month paper mill strike helped erode Clark's base and led to his recall. Almost as quickly as it flared, silence took over the media regarding the short career of Camas's Socialist Mayor. In the aftermath, Camas' first and only Socialist mayor was erased from public memory. Clark himself moved away from Camas in 1918 and lived a rather transient existence for the duration of his life. He appeared in Oakville, Washington, in 1920 for a short time. The next record of him was upon his death in 1926. In that year, he was laid to rest in the Canemah Pioneer Cemetery in Oregon City. Similarly, some of Clark's socialist allies dispersed and started over in other towns and cities. A few blended quietly back into the small community of Camas. All the participants have long since passed away. In Camas only vague memories circulating in oral tradition and local talk carry the audible remains of the Socialist upsurge and the strike of 1917-1918.

Cracks in this silence suggest that the 1917-1918 paper mill strike of the International Brotherhood of Paper Makers (IBPM) and the International Brotherhood of Pulp, Paper and Sulphite Workers (PPSW) in Camas was arguably the most vivid and transformative episode in Camas's history, widely hailed at the time as an imperative fight for not just the workers of Camas but for all in the nation. One of the strikers from Camas remarked in the Oregon Labor Press about his sense of place in history at the time:

3 “Strike Situation in Camas," Oregon Labor Press (Portland, OR), March 23, 1918. 
The Legislature of States, the Federal government, has long since conceded the right of labor to organize.... and arbitrate with committees of employees presenting grievances. Since the passing of the dark ages, since the advent of the Jewish and Christian religion, one day's rest out of seven had been conceded as the right of all toiling human beings, even of beasts of burden. Yet the managers of the paper mill deliberately forced their employees to work Sunday work, and some of the employees, failing to appear for Sunday work, were promptly discharged the next Monday morning. ${ }^{4}$

Despite this epic rhetoric, curious researchers must look hard in regional sources to find most physical and rhetorical traces of the strike. For example, research done to meet the national labor demands of World War II briefly surfaced its mention. In 1942, a report by Roger Randall of the Northwest Regional Council, developed in the 1940s to educate Northwest youth about the "under utilized" resources in the region, reflected on the strikes in Camas in 1917 and 1918. Randall wrote that "union organization of pulp and paper workers in the Northwest received its first start in the 'union boom' of 1917 and 1918, at which time local charters of both the International Unions were installed in the two large Crown Willamette mills... [and] these locals rapidly attained a considerable membership," but the unions failed, unable to compel Crown to recognize their new organizations. ${ }^{5}$ Randall also identified the workers' inability to gain recognition and "the company's...unswerving... anti-union hostility," as key factors in their failure, a failure that limited organization in the pulp and paper mills of the Pacific Northwest for the next decade. ${ }^{6}$ He wrote that "no attempt was made to revive union organizing in the Northwest

\footnotetext{
4 “Paper Mill Workers Ask for Fair Deal," Oregon Labor Press (Portland, OR), December 1, 1917.

${ }^{5}$ Roger Lewis Randall, United States. Bonneville Power Administration, and Pacific Northwest Regional Planning Commission, Labor Relations in the Pulp and Paper Industry of the Pacific Northwest (Portland, Or: Northwest regional council in cooperation with the Bonneville power administration, the Pacific Northwest regional planning commission, 1942), 50; Roger's incorrectly states that the second strike at the Camas mill started in 1918. The strike began in September of 1917 and continued for ten months. This must be noted here because Roger's error is reproduced in later works.

${ }^{6}$ Randall, United States. Bonneville Power Administration, and Pacific Northwest Regional Planning Commission, Labor Relations in the Pulp and Paper Industry of the Pacific Northwest, 50.
} 
mills through the 1920s," and only the establishment of the Wagner Act in the 1930s created a space for organized labor in the paper mills of the Pacific Northwest. ${ }^{7}$ Randall's conclusion resonates with scholars' subsequent findings in places like Bisbee, Arizona and Centralia, Washington. Labor upsurges before the Wagner Act left these communities torn, scarred, and unhealed. ${ }^{8}$ In contrast, the wounds in Camas were rhetorically covered and hidden. Most of the residents either never spoke of what happened or willed themselves to forget. The memory and knowledge of the events remains to this day imprisoned within their minds and town.

This thesis explores the tumultuous labor and political events in Camas, Washington from 1913-1918, as well as their active erasure at the time and forgetting since. One of the central contentions of this thesis is that erasure and denial or workers' power accompanied the series of strikes and political upheaval between 1913 and 1918 amid discussion of them in the public sphere. These silencings amid uproar partly account for the haunted, subjugated quality of the memory of working peoples' activism in Camas. Another aspect of the quashing of labor concerns gender. I suggest that labor, management, and the political establishment were invested in a particular gender order that privileged male-breadwinning at home and male voices in the public sphere. In a sense, labor's unwillingness to embrace female agency and voice-and management's willingness to manipulate gender expectations on the shop floor and in public debatesignificantly undercut workers' ability to effectively confront the conservative assault on

\footnotetext{
${ }^{7}$ Ibid, 50 .

${ }^{8}$ Katherine Benton-Cohen, Borderline Americans: Racial Division and Labor War in the Arizona Borderlands (Cambridge, Mass.: Harvard University Press, 2011); Tom Copeland, The Centralia Tragedy of 1919: Elmer Smith and the Wobblies (Seattle: University of Washington Press, 1993); The Centralia Case; Three Views of the Armistice Day Tragedy at Centralia, Washington, November 11, 1919: The Centralia Conspiracy, Civil Liberties in American History (New York, Da Capo Press, 1971).
} 
their union. Intertwined with the elements of gender, labor, and politics is evidence that these historical actors exhibited nuanced, often pragmatic, thinking, responsive to external considerations of the moment rather than dogmatic obedience to social norms or the dictates of ideology, left or right.

Many works concentrating on the Pacific Northwest and Washington, though not explicitly, present dichotomous political environment of fairly rigid conservative and radical viewpoints within the minds of workers, business owners, and politicians. For example, Dana Frank's work on Seattle in this period suggests that after the General Strike of 1919, labor maintained normative gender and family roles because the wives of organized male workers both supported unionization and an alternative economy through consumer cooperatives. By keeping menfolk in the union hall and womenfolk in the feminized sphere of shopping and food provisioning, workers sustained an activist, alternative vision for their community during the 1920 s. $^{9}$ The Camas story is shorter, more concentrated, and more intimate due to the brief timeframe of change and the accent on men's fraternal bonds in the town. Camas was a company town and "labor village;" the face-to-face quality of social relations — and the pressure to maintain a "village discourse" in opposition to "outside" voices vying to disrupt tradition—put special demands on the people involved. This thesis takes the concurrent labor and political environment throughout Washington into consideration during this seminal moment for gender, labor, and political roles in the state and nation and brings Camas and Southwest into the fold.

\footnotetext{
${ }^{9}$ Dana Frank, Purchasing Power: Consumer Organizing, Gender, and the Seattle Labor Movement, 19191929 (Cambridge England ; New York: Cambridge University Press, 1994), 1.
} 
Southwest Washington has received little examination by scholars concerning its role in labor and politics in the state. New primary resources, like the minutes of the Camas Commercial Club, help integrate this section of the state into a historical discourse traditionally focused on Seattle, Everett, Centralia, and Spokane. This paper centers on this usually peripheral section of Washington State and its role in the economic and political history of the Pacific Northwest. This claim is especially salient when the national labor scene is taken into account, since the paper industry was high on the list of those ambitious to organize U.S. workers before and during World War I. Indeed, how Camas's workers "played" in the regional media and national labor publications and the external reputation of the community overall are significant features of the analysis that follows. Such story telling and myth making remains salient into the present, since the region continues to play the role of "Eden" or "western innovator" in the national drama. To be sure, the labor upsurge in Camas became polarized and ideologically charged; however, the roots of dissent started with efforts to maintain the small town paternalist order between the company and the workers. Nascent resistance to perceived radical actions by workers and leftist politicians weakened not "labor" per se (nor "management") but rather strained the self-understanding of the community as a harmonious, moral, and benignly hierarchical. When this story about Camas "cracked," an environment was created for the ouster of foreign or alien outsiders (often labeled "German") and to discipline the unruly "children" (i.e., workers). In the end, the sharply paternalistic company and business interests of the city to returned to power stronger than before, even flouting the cajoling pressure of the federal government during labor mediation in 1918. 
The 1918 mayoral recall, my initial thread for this corrective reweaving of the history of Camas, piqued my interest over three years ago while assisting with a Southwest Washington labor history exhibit at the Clark County Historical Museum. From there I searched for more information and answers, which generated new questions. For the sake of full disclosure, I want to state that I was born and raised in the Camas/Washougal area of Southwest Washington. My roots, in part, drove my interest in this story. The thought of a socialist mayor in Camas seemed diametrically opposed to my concept of my hometown, which was of the benign and secure company town. How could I square this radical moment with my sense of the rural and conservative town from my youth? I became hungry for evidence of what happened in Camas in 1918. For the next three years, I sought out all available resources. I rummaged in archives, both digital and physical, libraries, historical societies, made calls via social media, and chased any possible lead to gather the long forgotten threads needed to weave together a tapestry of events during, before, and after this key moment.

What came to the surface was a complex, conflicted, and sprawling narrative that I argue is highly significant to the struggle for fair wages and safe conditions by the wageworkers in the pulp and paper industry. This struggle on the shop floor combined with a rising political radicalism in the partisan and electoral realm of Washington State. In the end, a strong nationwide ideological resistance to the ideals of Labor and Socialism played a significant role in undermining and delegitimizing the efforts of labor and leftist politicians in Camas, just in the rest of the state and nation. In this time, the city went from being a passive or default company town, to fighting for more inclusion, to then becoming an even stronger company town. Most striking to me was the tortured nature of 
the historical record itself. While no archive is perfect, at nearly every turn I perceived evidence of active forgetting and erasure of the past interlude of struggle. A significant example of this erasure was the ghostly "Slacker Obelisk" that was placed at the foot of the town, on the main throughway directly in front of the mill. In stone were the names of Camasonians that refused to support the war. In reality, the "slackers" had violated traditional village discourse of Camas, they questioned the war with their pacifism and they questioned the company by organizing a union and asking for better conditions.

\section{Why Camas? Why Southwest Washington?}

Academic histories of Washington State have rarely ventured into the smaller towns and counties of Southwest Washington leaving a large piece of Washington's narrative untold. This historiographical blinder overlooks the economic and political role of paper mill workers in the Pacific Northwest. Instead, the literature of the region is dominated by the more splashy International Workers of the World (I.W.W.) and radical politicians. ${ }^{10}$ Though the I.W.W. was important in labor and politics in the region, the conservative social tone of Southwest Washington and its tradition of stalwart support for Republican politicians kept I.W.W. all but excluded. My work corrects this omission of Southwest Washington and examines the role gender, labor, and leftists' politics played in this section of the state and the Camas paper mill. In the end, the coffin carried down Fourth Street in Camas, real or imagined, carried not only a dead political body but also the remains of Labors' early efforts to organize pulp and paper workers of the Pacific Northwest. The fight over its meaning and memory, then and now, is the subject of this thesis.

\footnotetext{
${ }^{10}$ For multiple essays on labor in Washington State see: http://depts.washington.edu/labhist/encyclopedia/browse.shtml
} 


\section{The Historical Context}

The first three decades of twentieth century saw a number of challenges in which politicians and laborers damned America's Gilded Age of greed and monopoly. In this new age, women, labor, and leftist politicians slung economic and political stones in the face of corporate Goliaths, rampant social ills, and political inequity. Historians have documented a series of social, even psychic or spiritual crisis in the 1890s: the "tramp question," the "woman question," the "Negro question," the "labor question."11

Historians contend that the early-twentieth century witnessed innovation and social reform, in a so-called Progressive Era of modernization, clean-ups, and rebuilt institutional infrastructure in law and government. ${ }^{12}$ The new century was a moment of soul searching for the nation socially, economically, and politically. The identity of the "American" was in flux. Many struggled to stake their own claim, including millions of new immigrants in major urban centers. Across class and race, women pushed against economic, political, and social barriers and ideologies. Radical-leftists and progressive

\footnotetext{
11 Theodore Stanton, The Woman Question in Europe: A Series of Original Essays (G. P. Putnam's sons, 1884); William Edward Burghardt Du Bois and Isabel Eaton, The Philadelphia Negro: A Social Study (University of Philadelphia, 1899); F.E.H. Raymond, “The Tramp Question," Frank Leslie's Popular Monthly, 1888.

12 Robert D. Johnston, The Radical Middle Class Populist Democracy and the Question of Capitalism in Progressive Era Portland, Oregon, Politics and Society in Twentieth-Century America (Princeton: Princeton University Press, 2013); Ronnie J. Steinberg, Wages and Hours : Labor and Reform in Twentieth-Century America, Crime, Law, and Deviance Series (New Brunswick, NJ: Rutgers University Press, 1982); Christopher L. Tomlins, The State and the Unions : Labor Relations, Law, and the Organized Labor Movement in America, 1880-1960, Studies in Economic History and Policy (Cambridge ; New York: Cambridge University Press, 1985); John C. Putman, Class and Gender Politics in Progressive-Era Seattle, Urban West (Reno: University of Nevada Press, 2008); William E. Forbath, Law and the Shaping of the American Labor Movement (Cambridge, Mass: Harvard University Press, 1991); William G. Ross, $A$ Muted Fury : Populists, Progressives, and Labor Unions Confront the Courts, 1890-1937 (Princeton, NJ: Princeton University Press, 1994); Nancy Woloch, Muller v. Oregon : A Brief History with Documents, Bedford Series in History and Culture (Boston: Bedford Books of St. Martin's Press, 1996).
} 
politicians opened new discourses questioning capitalism with ideas of reform and revolution, gaining traction across the nation in new political parties. Opposition to "social democracy" came from industry and corporations who maintained policies of non-recognition of unions and refusal to negotiate. Conservative Americans crafted a nationalistic identity wrapped in the flag and also in fear, frequently blaming racialized "others" as possible contaminants to the social order, who were then exploited for the benefit of industry. However, despite this volatility in the East and urban centers, some Washingtonians found ways to craft an environment in which women sought to have a voice, labor could gain state mandated workplace rights, and new political ideas could grow. The Pacific Northwest acted as a social, economic, and political frontier, mostly for white work and middle class Americans. Carl Schwantes explains this well in Radical Heritage. He writes:

Many a worker immigrating to the North Pacific industrial frontier was thus encouraged to develop a somewhat altered concept of his role in society. A worker moving to Washington in the 1880s might have perceived himself as a carpenter or miner when he left St. Louis or Scranton, but once in the expansive environment of Puget Sound he might see himself as a miner or molder or carpenter - and a participant in the creation of a new and more equitable society than the one he left behind. ${ }^{13}$

This sense of stakeholdership continued to hold true from 1900 to 1921 in Washington State. During this period Washington and its Northwest neighbors were fertile breeding grounds for the efforts of organized women, trade unions, and radical politicians. ${ }^{14}$

\footnotetext{
${ }^{13}$ Carlos Arnaldo Schwantes, Radical Heritage: Labor, Socialism, and Reform in Washington and British Columbia, 1885-1917 (Moscow, Idaho: Caxton Press, 1994), 7-8.

${ }^{14}$ The Women's Trade Union League did have a presence in the state; however, it was centered only in the Seattle and Puget Sound area. The only committee for the league in WWI was placed in Seattle.
} 


\section{The State of Women in Washington}

In this period, women citizens in Washington State asserted a great deal of power socially, economically, and politically. The strongest showing by women in the prestatehood period was the gaining of suffrage in 1883 . This victory was short-lived. The Washington State Supreme Court revoked the suffrage statute. Some speculated women's suffrage was revoked in Washington due to their voting patterns, which tended to restrict or eliminate liquor sales. Activist women of Washington continued to push for suffrage with other unsuccessful attempts and in 1910 women's suffrage in the state passed and held. In the following years Washington elected its first women to the state legislature, electing Frances Axtell and Nena Croake in 1912. ${ }^{15}$

Washington women also become active in the labor movement. In Spokane women gained positions on the local labor council and fought for the rights of workers, helping coordinate strikes in local laundries under the aegis of the their local council. In Seattle women, also working in laundries, went on strike for better wages and conditions. All across the state white working and middle class women were empowered by their new civic voice. ${ }^{16}$

\section{The State of Labor in Washington}

Suffering though lean years of the 1907-1908 economic downturn, organized labor in the state gained steam around 1909. That year the Washington State Federation of Labor (WSFL) saw significant growth. Their ranks increased by $13 \%$ with membership cresting at over 12,000. The United Mine Workers of America (UMWA)

\footnotetext{
${ }^{15}$ Shanna Stevenson, “The Fight for Washington Women's Suffrage: A Brief History,” Washington State Historical Society, n.d., http://www.washingtonhistory.org/files/library/TheFightforWashingtonWomensSuffrageABriefHistory.pdf 16 “Laundry Girls Strike,” Bellingham Herald (Bellingham, WA), April 27, 1911.
} 
District (UMWA) 10 primarily contributed to this growth. The WSFL steadily built their ranks from several hundred in 1903 to over 3,000 by 1908 . This success was tempered by difficulty making inroads in industrial and timber sectors of the economy. By 1910 growth of the WSFL membership hit unprecedented highs with an increase nearing $26 \%$ and a total membership of 15,000 . This growth was coupled with a growing laborfriendly voice in state politics.

Marion Hay, the newly elected Governor of Washington State, and many in the state legislature, backed labor and protective legislation bills aimed at workers. Organized labor in Washington State pushed and succeeded in getting labor legislation passed such as the Employers Liability Act and an eight-hour day for Washington miners. Organized labor in the state was enjoying unprecedented success in many places after struggling for so long during the Gilded Age. ${ }^{17}$ Labor's actions, overall, were mixed in the eyes of the media and coverage depended heavily on the publication. Urban papers, such as The Oregonian, were less favorable in their rhetoric towards labor action than rural publications like The Pullman Herald. ${ }^{18}$ At this time the Western Federation of Miners were extremely active outside of the major urban centers in the state.

\section{The State of Politics in Washington}

In the 1912 presidential election campaign of Eugene V. Debs, the national Socialist Party candidate and founding member of the International Workers of the World, garnered $12 \%$ of the vote from the Washington State electorate. This was one of

\footnotetext{
${ }^{17}$ Jonathan Dembo, An Historical Bibliography of Washington State Labor and Laboring Classes (Pacific Northwest Labor History Association, 1978), 76.

${ }^{18}$ Pullman Herald (Pullman, WA), March 21, 1903; "Montana Asks for Troops, If Needed. Governor Makes Request of President, Fearing 500 Militiamen Too Few," The Oregonian (Portland, OR), June 16, 1914.
} 
the best proportional showings by a socialist candidate in all of the States and best nationally by a third-party candidate at this time. In total, Debs received almost $6 \%$ of the national vote. ${ }^{19}$ Radical-leftists endeavored to gain key political positions. Socialists, Prohibitionists, and Progressives filled seats in state legislatures, on county commissions, and in city councils that were once held by Republicans and Democrats. Socialist candidates, in particular, gained mayoral positions in Edmonds, WA in 1911 and Burlington, WA in $1913 .{ }^{20}$ Also in 1913, Peter Jensen, a state senator from Pierce County, notably switched parties from Democrat to Socialist. It was reported that he declared himself a "Stars and Stripes Socialist." ${ }^{21}$ Couched in patriotic and cooperationist terms, leftist politicians worked with conservative, moderate, and radical labor organizers to pass labor legislation and apply pressure on businesses to improve wages, conditions, and agency for workers. It was politically profitable to run as a "friend of labor," but, at the first sign of weakness in labor's strength in the state, questions of patriotism came to the surface. Friendly alliances in politics struggled to withstand private backlash efforts, and many found themselves either removed from the position of power or remiss in adequate electoral support. For example, labor's recently elected "Stars and Stripes Socialist" Peter Jensen failed to reach the ballot in the next election cycle. Additionally, the leftist and labor coalition broke due to infighting within both radical political and labor circles. This left both elements weakened at the onset of the war and unable to retain newly gained positions. By 1919 most of the socialist leaders outside of the major

\footnotetext{
19 “1912 Presidential Election,” accessed June 14, 2015, http://www.presidency.ucsb.edu/showelection.php?year=1912.

${ }^{20}$ Dembo, 97.

21 "Jensen Says He Is a Stars and Stripes Socialist," The Bellingham Herald (Bellingham, WA), March 6, 1913.
} 
cities were scoured from positions of political power - if not imprisoned - and radical labor delivered blow after blow in courts and congress for its shop floor and strike activism. Only mild and paternalist legislation passed that symbolically pacified but did not advance real power, even as workers' rights remained visible in the statute and history books. ${ }^{22}$

\section{Those Who Have Come Before: Historiographical Examination}

The most important historiographical materials regarding labor organization and leftist politics as they pertain to the argument of this thesis are broad in scope. Historical research and writing of Southwestern Washington is minimal, if present at all, at a scholarly level. The earliest academic work discussing organization at West Coast pulp and paper mills is Harry E. Graham's The Paper Rebellion: Development and Upheaval in Pulp and Paper Unionism. ${ }^{23}$ Graham crafts a series of linked biographies of leaders, which map the development of the Paper Makers' and Pulp and Sulphite Workers International Union throughout the United States. In his second chapter, Graham briefly mentions the Crown Willamette strike of 1917-1918 that involved Camas and Oregon City, and, like Rogers, blames weak political infrastructure and intransigent management as the culprits in the failure of permanent organization in the industry; a situation that held until remedied by federal legislation in the $1930 \mathrm{~s} .{ }^{24}$ Local authorities had to be brought to heel by the Wagner Act in 1935s; such was the strength of local paternalism in the face of even mild pressures from federal agencies in World War I.

\footnotetext{
22 Jack Ross, The Socialist Party of America: A Complete History (University of Nebraska Press, 2015), 630-631; It must be noted that Ross incorrectly designates W.E. Farr, Mayor of Camas 1918-1920, as a Socialist and does not mention Oliver. T. Clark. Farr replaced Clark and was a Republican. In general, his list of Socialist politicians in Washington holds up to verification, however, there are some errors.

${ }^{23}$ Harry Edward Graham, The Paper Rebellion: Development and Upheaval in Pulp and Paper Unionism (University of Iowa Press, 1970).

${ }^{24}$ Ibid., 25.
} 
Jonathan Dembo disputes the perception that organized labor in Washington State was driven solely by a radical ideology, rooted in the leadership and masses of timber workers of the International Workers of the World (I.W.W.). The attention paid to the I.W.W. and radical leftists' in the big city was, he argues, was disproportionate to the reality of organized labors' economic and political disposition across the state of Washington. Dembo's exhaustive examination builds a significant case in support of his argument. The action of the state's most prominent labor organizations, such as the WSFL, the United Mine Workers of America District 10, and many others, are tentative, conservative, and themselves caught in the middle of the battle between the A.F.L. and I.W.W. over craft versus industrial unionism. ${ }^{25}$

Setting a scope that spans from the heart of British Columbia to the north bank of the Columbia River in Washington State, Carlos A. Schwantes in Radical Heritage: Labor, Socialism, and Reform In Washington and British Columbia, 1885 -1917 explores the roots of Northwest radicalism in both labor and politics. Schwantes's work is an excellent historical backdrop to help contextualize my work within the larger picture of Northwest radicalism. Schwantes demonstrates that radicalism and labor activism knew no boundaries, and organized against the national frameworks that typically bound U.S. political activities and parties. Instead of separate states or nations, Northwest radicals and labor unified by industry and across international borders. His argument holds true, to a degree, in Southwest Washington and Camas. There was coordination between the American and Canadian paper mills during the strike of 1917-1918. Indeed, when workers in Camas began identifying with fellow laborers regionally, nationally, even

${ }^{25}$ Dembo, An Historical Bibliography of Washington State Labor and Laboring Classes. 
internationally, well beyond "the labor village," elites fought hard to re-establish their dominion over "their" workers in "their" town.

Dembo and Schwantes's works appear in conflict. However, I read them as complementary. Each weaves through the gaps of the other and demonstrates the need for balance in the discourse of Washington State labor and politics. My own work focuses on moderate and radical forces unified in their efforts when necessary. They did not adhering to completely rigid ideological points of view. When the discourse between the workers, politicians, citizenry, and the company remained within the insular concept of the "labor village," that is, the physical public spaces within the town of Camas, interlocutors could agree on ends; the means were less important. My research shows when the conversation broadened to engage in the national environment of patriotism and fear, powerful members of Camas threw everything at reining in local labor and stamping out the conflagration of radical political ideas in "their" city, including jail and physical violence.

Building primarily from the works of Graham, Dembo, Schwantes, and several others, like Frank, each chapter is a ray reflected through the prism of labor's upsurge, especially in the three notable strikes from this time. The rays of time cross, but each narrative highlights unique factors. The first chapter centers on the important role Camas women played in creating a crucial precedent for organizing and activism; literally the women made labor news and national news, and they made it first. Thus a story became "tellable" about labor in Camas where none existed before, and various stakeholders weighed in to shape that story to their advantage. In their efforts, these women engaged in actions typical and atypical of strikes involving women workers at this time. However, 
the most important result of their actions was their pioneering of an expanded labor and political discourse, locally, regionally, and nationally. Despite the path blazed by Camas women in the strike of 1913, their voices in the city were stifled and contained through paternalism. Women's demands were met but their gains were minimized and their efforts cast as unnecessary. The company instead insisted on its intention to raise wages well before the women went on strike. Labor, for their part, rather than embrace the women's successful strike as a moment for empowerment, decided instead to goad the men and called into question the masculinity of the male workers. Labor chose to mute women's voices in public discourse of the "labor village" in an effort have men step up and compete in the public sphere. The social order in the town, state, and nation divided over the meaning and implications of the efforts by Camas working women. Because their action threatened the paternalistic order of both the town and shop floor, their story literally had to be forgotten or at least rewritten. Organized menfolk, however, bobbled the chance to reassert their own gendered authority as providers and protectors in the shop or streets. Eventually they fell victim to stronger forces allied against them. Chapter one thus examines a tear in the script; an attempt by inspired women workers to join the discussion over the economy and politics of the town. This tear, which was alternately denied and then poorly repaired, left a scar: the failure to unionize women workers.

Chapter two examines the series of strikes between 1917 and 1918 in which the male workers of the pulp and paper mills organized craft unions affiliated with the American Federation of Labor (AFL). The backdrop of shaky efforts to organize, the fraught conditions of male-dominated labor in the state, and the sidelining of women workers in activism, the stage was set for compromise. Compromise was staged in the 
electoral realm; with labor stirred up but frustrated in terms of gaining contracts, the Socialists asserted themselves in Camas, giving labor some "play" in town. All of these factors enabled and animated the male workers at the Camas mill to take stronger action, though they delayed fatally. In the end, Camas male workers' largest contribution of their efforts became the stalling of organization in the Northwest paper mills.

Chapter three focuses on the success of leftist politicians in Camas. The city was an established bastion for Republican politicians. The election of several Socialist politicians diverged strongly from tradition. With leftists new success came more attention from voices outside of the traditional discourse of the "labor village." Regional and national media, lecturers, and newcomers disrupted the long insular community discourse of Camas. No longer did the "village" take care of its own business, but the voices and eyes of "outsiders" sought significant roles in shaping economic and political outcomes locally. Labor gained in numbers both organizationally and at the ballot box; however, the business establishment feared the radical shift in the community. Alignment with the local and regional news media allowed Crown and business leaders to regain the reins of power and strengthen their grip permanently within the city. The leftist movement in the city inadvertently acted as a political mortar strengthening and solidifying the bonds between the community and the company. Starting as a company town, labor and leftists politicians fought to stretch the boundaries of the town's identity like a rubber band to the point of breaking. The goal was not revolution but reform. The primary goal was the establishment of economic and political independence for the people of Camas from the dictates of Crown. However, enough stress was never applied or supplied - and the band snapped back creating a tighter bond between the city 
government and the company. This ejected long time and established Camasonians from the "labor village" and left women citizens' voices diminished. When compared to similar events in Seattle, Brisbee, New York, and Lawrence, the denouement in Camas resulted in an overall shrinkage rather than accommodation of working peoples' voices either on the shop floor or ballot box. Notably for the state and other western locations for labor upsurges, Camas events unfolded without the racial and leftist scapegoating well documented by labor historians of other regions.

In the final chapter, the conclusion, these elements are reunited. Each ray has its individual path, yet they all coalesced in a final impactful moment. Women, men, workers, the company, and politicians met at a point in time and were then jettisoned from the community. In the newly consolidated town, the identities of the city and company became inseparable; threats of termination of employment, arrest, accusations of treason, community shaming, and public apathy worked as effective silencing mechanisms in the immediate aftermath. The local paper, ironically started by a Socialist leader, towed the company line. The city council bestowed namesakes from the executives of the mill on public parks and schools, literally renaming the town in corporate terms. Not until the 1960s did the lines between company, city, and workers show signs of separation. Rather than a pluralistic vision, or a happy democratic patchwork of peoples, the projected identity of Camas in public discourse, memorials, and memory was that of solidarity between the company and town, which excluded the voices of women, workers, and leftist politicians 


\section{Chapter I:}

\section{The Beginning: Forty Women in a Bag Factory}

The year 1913 was one of significant change for Crown Columbia Paper Company, its employees, and the city of Camas. ${ }^{1}$ The mill town on the Columbia River stood at the foot of one of the largest pulp and paper operations in the region, an operation that was at the heart of the Pacific Northwest's prolific timber industry. These workers and factories represented a strategic economic piece in a region whose habits of industrial political economy remained unsettled and unscripted. In January of that year, the company and its workers wrangled in a first-ever strike, in effect destabilizing the environment of the "peaceful labor village" that characterized the fabric of identity in Camas. Forty women from the Crown Columbia paper bag factory changed history when they walked out in January of 1913. Apart from their concrete demands, which were mostly met, the strike posed something of a crisis. What was the place of women in economic conversations in Camas? What was acceptable behavior in the public sphere? Who was truly responsible for economic conditions and decision-making at the mill? Though the women of the mill, like the Lowell Girls and the New York shirtwaist workers before them, lacked specific aspirations of organization beyond their initial demands, gendered issues in labor organization were nonetheless raised for all concerned. Indeed, the strike's "play" in the media was an enduring feature of this episode, as stakeholders near and far vied to take control of a moment of flux to advance their own interests.

Defining those "interests" involved less left-right ideological cleavages than a more traditional discourse, one that involved and linked the moral economies of family,

\footnotetext{
${ }^{1}$ At this time, the mergers that created Crown-Willamette had not yet happened.
} 
village, and factory. Ironically, then, as the women turned the heat up on the shop floor, they made themselves and their issues visible to sectors in town with a range of agendas, none of which they controlled. Regardless, this walk out, combined with the rising efforts of trade unions in the state and socialist politicians within Washington State and Clarke County, created an intense focus on Southwest Washington and Camas from those outside of the city and region. They hoped to gain a degree of control over workers at the mill in Camas and to claim some of the power of this principal cog in the industrial landscape of the state and region. Women remained involved in the growth of labor and leftist politics in the city. However, as their voices grew in strength, traditional silencing mechanisms were used to ignore or stifle their voices. In the end, the ability of the traditional powers of the "labor village" permitted only very limited participation of women in questions of economy and politics. While laborites tried to claim the women as a victory for their movement, Crown, through the local media, successfully turned the strike into an ideological endorsement of for "tradition," in which women's voices were tamed and subordinated. Crown took rather drastic measures to secure their top status in the local social, economic, and political order. Ironically, Crown's overreaching, especially on the issue of free speech and public expression, drew the fire of Portlandbased middle class radicals and feminists who tried to defend the striking women workers and in the process, shined a negative light on the village ethos of Camas.

Rooted in a national, even international wave of political and economic change driven by industrialization, the foundation for the unique but short-lived success of organized labor and the Socialist Party in Camas was established at in this time. Contrary to the more well known contemporary movements in the West, the catalysts of labor and leftist 
political change were not transient and migratory male timber workers or internationallyminded radicals, but rather, young American-born, white women, harkening back to Lowell. When compared to the East, where many striking women were newcomers to the United States and aligned with a European-inflected socialist ideology, the strikers in Camas were mostly second or third generation Americans, white and moderate, if engaged at all, in political activities. ${ }^{2}$ Like the menfolk of their region, Camas women leaned toward craft unionism and mostly eschewed radicalism. Despite their demography and temperament, the consequence of their actions, just as those in labor actions occurring in New York, New Jersey, and many other cities, drew the attention nationally of those with sharply left of center political views. ${ }^{3}$

Moderate and radical Socialists saw the strike as an opportunity to be fostered and capitalized on. Eventually, the shifting economic and political discourse of the "labor village" initiated by their efforts, disrupted the company-town hierarchy and the community's "story of itself." In its "story of itself," the mill was sovereign and all others, civic or private, conceded to the company's demands because mill drove the economic engine of the city. Nonetheless, the strike of 1913 marked a turning point from which there was really no turning back: a shift in the roles of women in the city, and an opening for a brief, but profound, shakeup of the rhetorical, economic, and political status quo of the "labor village."

The attention brought by the women of the bag factory was not that of revolutionaries but more so of reformers. No one challenged sex segmentation in industry or unions, so

\footnotetext{
2 Jennifer Guglielmo, “Transnational Feminism's Radical Past: Lessons from Italian Immigrant Women Anarchists in Industrializing America.(Report)," Journal of Women's History 22, no. 1 (2010): 11-12.

${ }^{3}$ Jonathan Dembo, An Historical Bibliography of Washington State Labor and Laboring Classes (Pacific Northwest Labor History Association, 1978).
} 
broad political mobilization was essentially moot. The striking bag workers received the community's silent endorsement of the strike and enjoyed restraint on the part of law enforcement. Unlike New York City shirtwaist workers who organized through the Women's Trade Union League and whose middle class women walked the line with them, no active, public coalitions developed to help the women challenge the unfair wages and conditions for women mill workers in Camas. For the workers and women of the mill, the patriarchal, top-down, and inequitable relationship between themselves and the company remained. Nevertheless, as a result of a two-week long turn out, the perceived peaceful environment and traditional "labor village" of the mill and town, in which the company, workers, and city existed with minimal dispute, was nonetheless radically altered.

The changed economic environment created by the turn out opened inroads for women of the city to engage in political and labor actions, especially in the suffrage and partisan arenas. The turn out even made high-profile women into targets for those opposed to a new social and political environment in the city. Only a few years after this strike, a weighty paradigm shift from a community centered on social, economic, and political conservatism to a short-lived embrace of leftist political ideals gripped the mill's employees and members of the city's leadership. The forty women on strike in the winter of 1913 initiated a brief but significant moment in Camas, the mill, and southwest Washington. The turn out created the opening for an organizing drive by the American Federation of Labor and a rhetorical opening for a number of new voices in Camas. Similar to other settings, like New York and Chicago, it was not the bag workers who only or even primarily benefitted from their own successful walk out in Camas. One of 
the legacies involved a handful of mostly middle class individuals who took on new caretaking and monitoring roles on behalf of the company, supervision rather than solidarity with the female line workers on the shop floor.

\section{From East to West}

In these same years, women workers nationally and in the Northwest called for improvements in their workplaces, challenged their communities' gender norms, and caught the eye of organized labor and ambitious leftist politicians. Enduring low wages and unsatisfactory and dangerous work environments, many women often struggle to stay healthy, make ends meet, and support their families. At times, these fights concerned life or death. Women working in factories positioned themselves in the public sphere to effect change. Though there had been a long history of women in the textile industry, especially fighting for better wages and conditions stretching back to the antebellum period at Lowell, the Triangle Shirt Waist fire of 1911 in New York City and the textile workers' strike of 1912 in Lawrence, Massachusetts, were key turning points for women and labor in the United States.

In New York the conditions for young immigrant women were extremely dangerous. In March of 1911 the deplorable conditions at the Triangle Shirt Waist Factory cost over 100 women their lives. Public anger over a seemingly preventable tragedy spurred growth in the International Ladies' Garment Workers Union (ILGWU). The National Women's Trade Union League (NWTUL), founded just a few years earlier, gained support to apply pressure to factory owners and open the doors to investigations. Both organizations operated within ideologies of protection and with classist assumptions, which could be alien to immigrant laboring women, especially those who 
were radicalized. The ILGWU often aligned with more radical labor efforts and contrasted with the NWTUL's more liberal and affluent members. Neither group necessarily had their hand on the pulse of the community. ${ }^{4}$ The New York City story is notable less for its gains for women in trade unions as portended by their strike of 1909 as for the reformist, protective outcomes in the wake of the fire of 1911. A sensationalist cautionary tale about victimization topped the media, rather than a rousing story of power gained by poor women in the public sphere. ${ }^{5}$ The main political legacy of these upsurges was "protective labor legislation," a raft of state-level laws, commissions, and regulatory efforts to improve safety and working conditions (wages, hours) for certain groups of women wage-earners (especially white, urban young women) rather than empower women per se within the polity or organized labor movement. ${ }^{6}$

Unlike the movement derived from the dangerous conditions and exploitation of workers in New York City, the Lawrence textile worker strike, often referred to as the "Bread and Roses Strike," was the product of a wage dispute. The majority of the women on strike hailed from a variety of immigrant backgrounds and previously employed by various mills throughout the city. ${ }^{7}$ The mill workers received a pay cut resulting from a new hours law passed in Massachusetts. This immediately sparked a firestorm of worker

\footnotetext{
${ }^{4}$ Heather N. Pool, Political Mourning (Thesis PhD--University of Washington, 2011), 183; Guglielmo, "Transnational Feminism's Radical Past," 15-18; Susan Amsterdam, "The National Women's Trade Union League," The Social Service Review, 1982, 259-72.

${ }^{5}$ Argersinger, Jo Ann E. The Triangle Fire : A Brief History with Documents. Bedford Series in History and Culture. Boston: Bedford/St. Martins, 2009

${ }^{6}$ Alice Kessler Harris, Wage-Earning Women; and her Kessler-Harris, Alice. In Pursuit of Equity :

Women, Men, and the Quest for Economic Citizenship in 20th Century America. Oxford ; New York: Oxford University Press, 2001.

${ }^{7}$ William Cahn, Lawrence, 1912 : The Bread and Roses Strike (New York: Pilgrim Press, 1980), Preface; 96; Bruce Watson, Bread and roses : mills, migrants, and the struggle for the American dream Penguin Books 2006.
} 
discontent emitted from the Everett Mill, one of the largest in the city, and quickly conflagrated to 20,000-worker strike. The workers in Lawrence were on strike for two months. In this case, allies and opportunists swarmed to their side. A young union, the International Workers of the World (I.W.W), with the goal of creating one big unified Union spanning trades and industries, came in full support of the women and workers at the mill. They successfully used the strike as an organizing opportunity, an episode well documented by labor historians, such as William Cahn and Bruce Watson. ${ }^{8}$

Union members and leaders of the I.W.W were socialists and viewed Lawrence as an important site for organizing workers and political change. Furthermore, with the attention paid to the strike, their efforts garnered recognition and support for their ideals nationally, including among middle class radicals, journalists, and labor intellectuals. When the strike erupted, I.W.W organizer Joseph Ettor and Arturo Giovannitti of the Italian Socialist Federation of the Socialist Party of America asserted leadership. Through the efforts of the workers and the I.W.W, enough pressure was applied on the employers of Lawrence to extract compliance with the workers' demands. Improvements in both wages and conditions in the city's mills came to fruition. Workers attained a $15 \%$ increase in wages and an agreement that management would meet with grievance committees. These gains were not sustained nor did they provide a strong future infrastructure to address poor wages and conditions. Nevertheless, the labor community and leftist politicians propagandized the Lawrence strike as a momentous victory for

\footnotetext{
${ }^{8}$ William Cahn, Lawrence, 1912; Bruce Watson, Bread and Roses : Mills, Migrants, and the Struggle for the American Dream (New York, NY: Penguin Books, 2006).
} 
women workers and a standard to bear in future labor actions. ${ }^{9}$ This sort of split legacy or split memory is salient in considering the varied meanings of labor's upsurge and are especially salient in the Camas case.

Largely ignoring the Pacific Northwest, academic historians have followed the road of women's labor actions from Lawrence through Paterson, New Jersey, New Bedford, Massachusetts, and Gastonia, North Carolina, to only name a few. During a period when workers were under assault, women in cities across the nation fought for meaningful changes. Gains within the ranks of trade unionism were limited and the voices and agendas of east coast big city immigrant workingwomen were often mediated and interpreted by middle class reformers. The result was less unionizing and more protecting through state legislatures, a remedy that maintained the basic gender assumptions that men should be breadwinners, and women ideally married and at home. ${ }^{10}$ Though with less violence and with little notoriety, in comparison to New York and Lawrence, the efforts of Northwest women in efforts to effect change in labor and politics were just as decisive as those in the East, but they functioned in a distinctive political climate with a different outcome.

\section{The Women of Camas and the Rise of Labor}

Having won the right to vote in 1910, Washington women citizens were empowered with a new public voice. They now held the power to engage and be heard in the political discourse of their state. Riding this tide of change, in the economic actions taken by

\footnotetext{
${ }^{9}$ William Cahn, Lawrence, 1912; “Open Collections Program: Women Working, Lawrence Strike of 1912," accessed June 14, 2015, http://ocp.hul.harvard.edu/ww/lawrencestrike.html; "History | Bread and Roses Centennial,” accessed June 14, 2015, http://breadandrosescentennial.org/node/77.

${ }^{10}$ Annelise Orleck, Common Sense \& a Little Fire: Women and Working-class Politics in the United States, 1900-1965 (Chapel Hill: University of North Carolina Press 1995). Kathryn Kish Sklar, Florence Kelley and the Nation's Work (New Haven: Yale University Press, 1995).
} 
women nationally and their rights to suffrage within their state, women in Washington State factories saw little issue with making open and public complaints against unfair wages and unsafe working conditions. Furthermore, two years before the women of Washington State gained suffrage they witnessed the United States Supreme Court uphold a protective hours law in Muller v. Oregon. This encouraged women and progressives to combat unfair practices and unsafe conditions in the workplace, particularly since much of this discussion was ensconced in rhetoric of protecting motherhood, home, and family. Consequently, Washington women struck to address the failings of their employers. When they spoke, however, they spoke in the language of equality in the economic marketplace.

One of the earliest examples of a labor action conducted by women in Washington State took place just a year after gaining statewide suffrage. In 1911, sixteen women at the Washington Laundry in Spokane went out on strike in response to "the introduction of piece-work payment and demanded a straight scale of 14 cents an hour." 11 In Spokane at this time, women were already very active in the labor scene. For example, Rose B. Moore was a local organizer for the Sectional Labor Council in Spokane and the primary organizer of the picket in the strike. By May, a committee made up of the striking women started talks with the management of the laundry to resolve the dispute. Later reports indicate the women of the Washington Laundry succeeded in their efforts and women led labor organizations cropped up in other laundries in the city. This initial

11 “Laundry Girls Strike,” Bellingham Herald, April 27, 1911. 
effort demonstrated that the women of Washington possessed a new voice in the economic and political discourse and took actions to impact necessary changes. ${ }^{12}$

In the winter of 1913, forty women employed at Crown Columbia Paper Company's bag factory joined the many women in textile factories and laundries across their state and nation in challenging both labor conditions in their workplace and gender norms of their community. Just as in other strikes, organized labor and radical leftists took notice of their actions in national journals and newspapers. Their eyes turned to the city of Camas. ${ }^{13}$ The strike lasted roughly two weeks and resulted in a compromise. But, the impact on the city was felt for years to come.

\section{Women of Camas in Context}

While the women in New York, Lawrence, and Camas shared similarities in their efforts, there were key demographic differences between women from these very different sections of the country. The extent of the efforts by women in Camas in 1913 remained isolated from the networks of support that made a difference at Lawrence and New York. Though largely untested, local norms and Camas's "story of itself," driven by Crown, were the main political currency of village life. Thus the women strikers walked a number of lines when they turned out that winter and took up public space with their demands.

In New York, Lawrence, and Camas the women were all young. From available census records it appears the mill in Camas employed very few, if any, children, male or female. This demographic is significant because no sympathy-inducing images of sweet

\footnotetext{
12 “Laundry Girls out on Strike," Spokane Daily Chronicle, Apr 27, 1911.

${ }^{13}$ The Paper Makers Journal (International Brotherhood of Paper Makers, 1913), 4; John G Wanhope, "The Slaves of Camas Mill," The Commonwealth, February 27, 1913.
} 
but ragged little children working in the mills, as popularized by Lewis Hine (18741940), figured in the case against Crown. The majority of women working at the bag factory were in their late teens and early twenties, and some had graduated from the local high school before gaining employment in the mill. In contrast to the striking workers at Lawrence, most of the women on strike in Camas were born in the Midwest or were second-generation native daughters of the city and American citizens. Lastly, many still lived with their parents in single-family homes. ${ }^{14}$ Conversely, the workers of Lawrence lived in tenement buildings that were overcrowded and dangerous. Incorporated in 1906, Camas was still a young and relatively wholesome small town (despite the stench of the paper mills), associated with the freshness and possibility of The West. Thus a distinct landscape of family, community, and belonging shaped the possibilities of women's labor action in Camas.

Casson N. Beagle, known to her family as Cassie, was one of the women that went on strike in Camas and typified the group's demographic. Unlike many of the women going on strike in the factories of the East, Cassie's parents were born in the United States. Her father Almon hailed from New York and her mother, Ruth Ann, came from Michigan. Cassie was also born in Michigan and came to Camas, Washington with her family before 1910. Almon took up trade in the city as a carpenter, while his son managed a local lumber mill. By twenty-two Cassie found work as a machine operator at the bag factory joined by her sister Catherine, who was a bag maker. ${ }^{15}$ Women, such as

\footnotetext{
${ }^{14}$ Year: 1910; Census Place: Columbia, Clark, Washington; Roll: T624_1655; Page: 8A; Enumeration District: 0058; FHL microfilm: 1375668

${ }^{15}$ Year: 1910; Census Place: Columbia, Clark, Washington; Roll: T624_1655; Page: 8A; Enumeration District: 0058; FHL microfilm: 1375668; Ancestry.com. U.S. City Directories, 1821-1989 [database online]. Provo, UT, USA: Ancestry.com Operations, Inc., 2011.
} 
Cassie, young and still living with their parents, may have been viewed by the mill's management as dependents and may have felt empowered to ignore their demands (much like New York immigrants). This overconfidence is implied by reports that the company was "using unfair methods...trying to break the strike and force them back to work at the company's terms." ${ }^{16}$ However, the women had the support of the "labor village" behind them and more social currency than mill management. Their mothers, fathers, brothers, and sisters worked in the mill and lived in the city while the upper management for the mill lived in Portland and Oregon City. At this time the voices of those from the "labor village" countered more than those from outside.

The bag factory strike of 1913 was the first widely noted strike at the mill in Camas and should be viewed as the origins of organization in the city. The dispute began over wages and conditions at the mill. At the time of the strike, women in the mill's bag factory earned $\$ 1.10$ per day. This amounted hourly to roughly $\$ 0.11$ to $\$ 0.13$ an hour. Nationally, wage earners in manufacturing industries earned $\$ 0.27$ an hour. Even if Crown considered the bag factory workers as unskilled laborers, the average wage for unskilled workers in 1913 was $\$ 0.19$ an hour. ${ }^{17}$ The women saw an increase to $\$ 1.50$ per day as fair and necessary. In addition to the poor wages, the working conditions in the bag factory were unacceptable and dangerous, the primary issue being the ventilation in the factory. These grievances regarding conditions were compared as"... similar to those

\footnotetext{
${ }^{16}$ Lynden Tribune, February 20, 1913 - Note: All reports aside from the Lynden Tribune, a paper out of Lynden, Washington, verify that the strike ended on February 12, 1913. It seems the Tribune and other state publications had not been made aware of the end of the strike until much later after terms were agreed upon by the workers and management.

17 "HistoricalStatisticsoftheUnitedStates1789-1945.pdf," 67, accessed April 13, 2015, http://www2.census.gov/prod2/statcomp/documents/HistoricalStatisticsoftheUnitedStates1789-1945.pdf.
} 
existing in Lawrence, Mass, previous to the textile strike." ${ }^{18}$ Encouraged by the efforts of women in Lawrence, Spokane, and other cities across the nation and state, it is clear that the women of Camas were aware of challenges to unsatisfactory workplace conditions across the nation by other women. The success these women in gaining redress must have been an encouraging factor — and potentially a worrisome one to management.

By refusing to negotiate, Crown intended to break the strike by denial and silence. Crown was not concerned enough to concede the workers' point, even to avoid a lengthy strike or any subsequent media attention. Immediately after the women walked out, the mill's management made it explicitly clear there would be no negotiations; quickly they issued a statement refusing to meet with the women to discuss their demands. A major driver of the company's refusal was their allegiance to an ardent policy advocating "open shops" and non-recognition of any employee led organization. Their membership in the National Association of Manufactures, which was the fountainhead of an "open shop" philosophy spreading through the manufacturing sector, demonstrated their alignment with the "open shop" ideology and their determination to keep unions out of their mill. ${ }^{19}$ The management and leadership of Crown, most living either in Oregon or California, took their lead from national labor ideals and for as long as possible ignored the dictates of the "labor village."

Firm resolve underpinned the women's walk out and the workers dug in. Crown's miscalculation here created time and space for organized labor and leftist politicians to move in and shape the meaning of the women's walk out. As the major

\footnotetext{
${ }^{18}$ Lynden Tribune, February 20, 1913

${ }^{19}$ Eric Arnesen, Julie Greene, and Bruce Laurie, eds., Labor Histories: Class, Politics, and the Working Class Experience (Urbana: University of Illinois Press, 1998), 73-78; American Trade Index (National Association of Manufacturers., 1913), 70.
} 
employer in the city, the mill's management believed that they could simply replace the women out on strike with other workers from the local area. Soon after the strike had started, mill manager, Alexander J. Lewthwaite, hired two women and one operator in an attempt to resume operations. Lacking skill, experience, and sheer numbers of workers adequate to run the mill, the effort resulted in complete failure. ${ }^{20}$ After this initial attempt, the women on strike no longer needed to worry that replacement workers would undermine their protest. The company did not attempt replacement again for the duration of the strike.

Lewthwaite was strongly inclined to not concede company's profits to the workers, maintaining an "open shop," and standing strong in non-recognition of any employee-led organization. In the context of the "labor village," Lewthwaite was an outsider possessing little social currency of the village with his lack of social and familial ties. Like most of the upper management at the mill, he did not live in Camas. Lewthwaite's father had a storied history in the local paper business but primarily in Oregon City with only a brief time in Camas. The senior Lewthwaite ran the first mill in Oregon City that supplied paper for The Oregonian. The family had a connection with the paper's owner Henry Pittock, who established the mill in Camas and continued to hold interest in the Camas mill. Just before the senior Lewthwaite's retirement, he supervised the construction of the mill in Camas, but from all records never took up residence in the city. The younger Lewthwaite followed in his father's footsteps and "spent nearly his entire life in the paper business," eventually reaching the heights of

${ }^{20}$ Oregonian February 5, 1913 
executive vice-president of the Crown Willamette Paper Company in later years. ${ }^{21}$ For Lewthwaite, the women's actions infringed on to the company's economic sovereignty, the "open shop" philosophy, and his familial legacy. His father managed Pittock's paper mill on the Clackamas River for many years and over saw the construction of the Camas mill just before retiring. The younger Lewthwaite worked in the mill with his father and witnessed his dedication to the operation. Upholding his father's legacy may have contributed to younger Lewthwaite's almost protective efforts to stifle dissent among the workforce. Yet, as Crown began to lose money from the shutdown, Lewthwaite's hand was forced to consider negotiations.

As January turned to February, Crown relented and became willing to meet the women at the negotiation table. A line of communication with a strike committee was opened. Negotiations were led by Superintendent of the bag factory and Camas Mayor James W. Duval. They were ineffective. The strikers remained firm about gaining the desired concessions, even in the face of meeting with arguably the most powerful person in town, their supervisor and the city administrator.

The wage-earning members of the community remained silent, allowing the matter to play out. Mothers, brothers, and fathers of these workers, who themselves worked at the mill, left nothing in the historical record to indicate action on their part. However, members of the business community began to take a more volubly paternalistic view of the situation and expressed it in the media.

Some felt they intimidation might end the strike, which was evident in a spontaneous confrontation with a "mediator" and the strikers. Walter H. Durham,

${ }^{21}$ Technical Association Papers (Technical Association of the Pulp and Paper Industry, 1935), 553;

"Lewthwaite Rites Set," The Oregonian (Portland, OR), January 25, 1932. 
manager of a clothing department in the local MacMaster \& Company store, stepped in as a self-appointed mediator. ${ }^{22}$ From all accounts Durham was firmly in league with the company for the duration of his life in Camas. In 1918, he was a signatory to the recall petition submitted to oust the anti-company Mayor O.T. Clark. In this specific case, it The Oregonian reported that Durham, "tried to emphasize his argument by force," believing he could use aggressive behavior against the women. Durham seemed to imply that by taking up public space, the women lost their claim to familial or community protection. The women disagreed, insisting not on "protection" by protectors but on selfprotection. Durham's tough talk "resulted in his being rolled in the mud by the girls." 23 Organized labor would not soon forget this point and in future disputes this incident would be referred to often. In a sense, the local media, The Oregonian, and the national journals created instant labor folklore about self-defense, self-directed protest, and selfprotection for the workers.

With Durham's failure, reports of more discussion between Duval and the women, absent from the archive due to a lack of documentation, were deemed failures by local media sources. ${ }^{24}$ Significant damage had been done to Duval's political standing due to his inability to quell the rebellion of Camas workers and citizens. In just a few weeks after the strike was settled, Duval stepped down as the city's executive. Although no reason was publicly reported for his resignation, it was speculated that his failure in resolving the strike was, at least in part, responsible. In other words, local womenfolk had discredited a Camas city "father." Duval continued managing the bag factory but his days

\footnotetext{
${ }^{22}$ Oregonian, February 5, 1913

${ }^{23}$ Vancouver, Washington, City Directory, 1914; Oregonian, February 5, 1913

${ }^{24}$ Year: 1910; Census Place: Columbia, Clark, Washington; Roll: T624_1655; Page: 15A; Enumeration District: 0058; FHL microfilm: 1375668.
} 
as a politician were over. The women of the bag factory proved that they would not be intimidated by force or power into relenting on their demands. However, the efforts at intimidation of women workers did not end there.

Duval's negotiations were stymied by his efforts to apply economic intimidation to subdue the strikers. The point was to economically cripple the women's ability to survive. The Paper Makers' Journal, the national voice of the IBPM, reported that as "soon as the strike started the mayor of the city visited the principal storekeepers of the town and pleaded with them to refuse credit to the strikers until they returned to work." 25 This effort fell on deaf ears. Instead, the local moral economy of self-protection and solidarity came to the foreground. The storekeepers and the striking workers comprised a small and close-knit community of 2,500 people. To deny fellow Camasonians daily and necessary staples was not an option and "public sentiment... was with the girls."26 Though reports of public sentiment and the action of the community backed the strikers, it must be noted that no public declarations of support were made. The code was implicit, and the protection could be read as duty toward weaker, needy "girls." Nevertheless, the support of the community, even tacitly, impacted the ability of the women to remain on strike. Securing the favor of the local moral economy remained paramount, for the most part, in this dispute. Soon Crown realized that true negotiations would be required to put an end to the strike. Managers were not "fathers" with trust and mutuality flowing between them and the city's residents. Crown did not have the moral high ground against the women within the "labor village," so concessions were made.

\footnotetext{
${ }^{25}$ The Paper Makers Journal (International Brotherhood of Paper Makers, 1918), 4.

${ }^{26} \mathrm{Ibid}$.
} 
By the second week in February, Lewthwaite began to meet with the women and negotiate an end to the strike. In future disputes, Lewthwaite fought vehemently to not be placed in this position again and remained opposed to negotiating with or recognizing employee led labor organizations. On February $12^{\text {th }}$ the strike was resolved. Lewthwaite and the women settled on a wage increase to $\$ 1.25$ per day as of March $1^{\text {st }}$ "providing they returned to work immediately at the old scale of $\$ 1.10 . "{ }^{27}$ Though not the full increase and still greatly below the national averaged for the industry, the new wage was an important win for the women of the bag factory. Even in compromise, the company expected the women to follow their lead and maintain the appearance of the power over the workers. For several weeks the women in the bag factory carried on work at the old wages and eventually gain their concession, but under Crown's conditions and timetable.

The women also negotiated improvements to the general working conditions in the mill. The Oregonian reported that "City Health Officer Dr. E.A. Lupton...inspected the factory... and recommended a fan and better ventilation conditions" for the workers. ${ }^{28}$ Crown agreed to this change. With improved wages and conditions the women of the bag factory returned to work the following Monday. Conditions objectively improved. Equally important, a new story-about-itself could be told by Camas: we take care of our own and sometimes the womenfolk have to remind us of our own tradition. However, radical leftists were not prepared to end the conversation and in one pointed piece, railed against the company and city.

${ }^{27}$ Oregonian, February 13, 1913

${ }^{28}$ Ibid. 


\section{Rising With New Labor and Political Ideas}

In 1913, following on the heels of Lawrence, Pacific Northwest labor organizations and radical leftists took ever more careful note of labor actions locally and nationally. As a result, these organizations often built a presence in cities and towns where workers conducted strikes or organization was possible. The women of Camas through the strike caught the eye of organized labor and radical leftists. A foundation was laid for economic and political change in the city, not only for women, but for all citizens and workers.

The forty women of the Camas bag factory initiated a push by labor within the city of Camas to demand better wages and work conditions. The scope of their efforts went well beyond the Camas city limits. The strike was closely followed by the national Paper Makers' Union in New Jersey. In the 1913 the Paper Makers'Journal remarked on the efforts of the women strikers of Camas in some detail. A full article about the strike and the resolution was penned. In an article titled "Bag Makers Win" they reported:

A number of girls are employed in a bag factory in connection with the big paper mill...these girls went on strike nearly a month ago for higher wage and better working conditions. They were unorganized. The strike, however, had been settled and the girls have been granted the concessions [sic] which they asked, the new conditions to date from March $1 .^{29}$

In 1913, the IBPM and other affiliated unions had little to no presence in the city. With a population of some hundreds of workers in Camas and its environs, the IBPM and many of the locals across the nation desired solid union organization in Camas and Oregon City. The Powell River mill in Vancouver, B.C. was the standalone bastion of organization in the Pacific Northwest paper industry. The IBPM used the strike to put the

${ }^{29}$ The Paper Makers Journal, 1918, 4. 
working-class of Camas and Oregon City on notice. The strategy they used was to goad the male workers by attacking their masculinity. The Paper Makers Journal chided the men of Camas and Oregon City writing "we learn that the Paper Maker girls of Camas, who have the eight hours at present, are striking for still better conditions. This ought to set a good example for some of the boys of Camas and Oregon City, especially those who are lacking in backbone and gray matter."${ }^{30}$ The national officers of the IBPM were enthusiastic and hopeful because of the effort of the striking women in the Camas bag factory. However, their celebration of the striking women's effort waxed dismissive and patriarchal. The article focused on shaming the men of the mills for their lack of organization. The subtext clearly emphasized that the men should have felt ashamed the "girls" acted first. The IBPM, just as the anti-labor media sources, only referred to the women on strike as girls. Even in celebrations of the women's efforts, in the words of labor they remained "girls." The connotation implied their efforts were admirable, but organization needed men. Labor was not alone in recognizing the efforts of the "girls" in the bag factory. Radical leftists' eyes were also drawn to Camas. They did not trivialize the women's efforts in the strike as organized labor had, but rather called out the system of gendered wage inequality that underwrote the exploitation of all workers.

\section{Wages and Slaves: Leftists Politicians Focus on Camas}

The women's strike and management's actions garnered the attention of radical leftists in the state of Washington who were eager to challenge the power of the Oregon City and Camas mills. These industries suffered from the continued stifling of organization, unfair wages, and poor conditions. Seeking to blunt the gender cleavage in

${ }^{30}$ Ibid., 36. 
the interest of solidarity across the industry, radicals reached back to antebellum rhetoric about "wage slavery." As the Camas strike was nearing settlement, a leftist newspaper, The Common Wealth, published a lengthy diatribe against the owners and managers of the mill. Prominent organizer for the Washington State socialist party, John G. Wanhope composed "The Slaves of Camas Mill." Wanhope wrote:

The mills of the Crown Columbia Co. grind slowly but they grind exceedingly fine; they grind trees of the forest into paper pulp, and the bodies and souls of men and women in to dividends, upon the bent backs of 400 wage-slaves the ruling masters have erected a temple to the God of profit...The little town of 'Camas' grew up around the mill, and the company succeeded as a rule, in having the town officials under their control. The present mayor is an employee of the company. ${ }^{31}$

Wanhope argued that a strong organization of workers at the mill would address the inequality and poor conditions at the Camas mill. His use of the rhetoric of "wage slave" is a point of interest, as it cut against the "harmony of interests" rhetoric typical of the nineteenth century and its echoes in the twentieth-century mill village. Socialists in Washington State used the term "wage slave" in abundance. Radical publications such as The Common Wealth, The Washington Socialist, and Labor Journal out of Everett, Washington, constantly used the term, which, in a sense, "Americanized" the class struggle. The term even graced the pages of progressive and independent papers such as The Seattle Star and Tacoma Times intermittently. ${ }^{32}$ The implication of such consistent use of the term "wage slave" was to tie companies, such as Crown Columbia, to the excesses of the Gilded Age when that term was at its height of popularity, given the recent defeat of slavery in the U.S. Yet, nowhere in Wanhope's rhetoric surfaced

\footnotetext{
31 "The Slaves of the Camas Mill," The Common Wealth, February 27, 1913.

${ }^{32}$ For examples see: The Commonwealth. (Everett, Wash.) September 18, 1913; The Washington Socialist. (Everett, Wash.) 1June 11, 1914; The Labor Journal. (Everett, Wash.), March 10, 1911; The Seattle Star. August 6, 1912; “The Tacoma Times. (Tacoma, Wash.) February 05, 1914.
} 
advocation for challenges to the gender norms of male breadwinning and female dependence. Instead, he focused on the economic inequalities while joining the company, business interests of Camas, and the IBPM in denigrating the efforts of women.

Wanhope pointed out that the demands of the women, if fulfilled, could create discord amongst the men of the paper mill. He felt this outcome should be avoided, on gendered terms. He explained:

To the casual observer it might be thought bad policy for the company to refuse the women employes (sic) the sum demanded, but here is the position they find themselves in. The men employes (sic) receive from $\$ 1.75$ to $\$ 2$ per day for an average of twelve hours...If they should pay $\$ 1.50$ to the women for eight hours it would be more in ratio than the men are getting for twelve hours, which might result in the male wage-slaves manifesting a spirit of revolt. ${ }^{33}$

In other words, radicals sought to goad the men into a fighting posture by challenging them to make more money than women in the industry. This was very thin theorizing from a major representative of the ideals of the Washington State Socialist Party. Wanhope's writing expresses a wariness concerning raising wages for women in the bag factory above the wages of their male counterparts (one of the unintended consequences of "protective legislation" for women workers). Unlike the company, business leaders of Camas, and IBPM, Wanhope called the strikers "women." This was the only instance in all the media coverage when they were not referred to as "girl," a word that has a minimizing, even trivializing, implication. However, even though Wanhope was calling for a revolution in the mill, his fear of dissent from male workers over the gender gap in wages stands out. The Washington State Socialist party advocated economic change and from Wanhope's words, gender equality was not a condition of such change.

33 "The Slaves of the Camas Mill," The Common Wealth, February 27, 1913. 
Regardless of the gender dynamic, the leadership of the Socialist Party recognized the bag factory strike as an exploitable wedge, prime to create a gap between the procompany city administration and the quietly "friend-of-labor" spirit of the broader community. If socialists gained political power in the city, a more conducive environment for labor organizing could be created, lending prestige to the Socialist Party given the high profile of Crown. Seeing this opportunity, the Washington State Socialist Party turned toward the Camas mill and the city. By 1916, Socialist politicians dislodged key pro-company officials in elective office and opened the door for labor in the partisan realm. This outcome was significantly to the credit of the women in the bag factory that initiated change with their strike in 1913.

This opening for leftist politics in Camas was widened by the nature of Northwest politics at this time. The isolation of Camas kept its village moral economy afloat, seemingly apart from the ideological polarizations evident at Lawrence, as well as early fear of war as tensions began to rise in Europe. Although Camas's radical left labor and politicians would be torn from office in 1918, in 1913 a shift in the "labor village's" traditional political conservatism began to be thinkable. The women of Camas broke new ground in the city regarding labor and politics. In the shifting political dynamic from Republican to Leftists in the partisan scene, the activists, if not radical women, of Camas were in the mix.

\section{Silencing Women's Voices with the Law}

Women continued to fill positions at the bag factory and in other occupations in Camas. However, in the realm of labor or politics between 1913 and 1917, femaledirected efforts went unnoted in public forums. No news accounts, committee minutes, or 
labor publications recount women's participation in local economic or political issues. Apparently, the Camas version of self-protection, men of the womenfolk, went thus far and no further. However, in the election of 1916 the landscape for Camas women shifted again when the Republican political establishment accommodated leftist politicians in a brief window of "friend of labor" electioneering. As the new city administration engaged in political discussions in the news media and Town Square, tension between the workers and mill management rose once again. In the short term, labor's toehold in electoral politics gave workers cover, and, like the cities of Chicago and Paterson, they pushed their opportunities where they saw them on the shop floor. A friendlier political environment allowed them to challenge the company with much less fear of local police action or violence. Several women stepped into leadership positions in the city and played significant roles in the political and labor struggles during the fall and winter of 1917-1918. In response, the business interests of the city worked around local politicians to deploy their own law enforcement against workers. This action resulted in the arrest and trials of two women activists. Equally important, it undermined, even assaulted, the former story Camas told of itself about its moral economy and the protection of womenfolk.

In September of 1917, the workers of the Camas Paper Mill once again went on strike. Having established craft-based organizations in April of that year, the workersmale and female--were now determined to force the hand of the company to recognize the new unions. Not long after the beginning of the strike, pickets were organized in front of the mill at the main road through town. Just as the women of the bag factory had in 1913, women were present and active on the lines in 1917. They were a diverse group, 
comprised of younger, mostly unmarried women from the mill and wives of mill workers. Leadership of the new union walked the picket and worked to deter strikebreakers from crossing the lines.

The business leaders' reaction to women on the picket lines shifted from the sentiment of 1913. Instead of addressing the women on pickets themselves, they employed county law enforcement to clear the streets. Business leaders felt the infiltrating forces of the new Socialist administration and labor threatened their free hand in the city. Feeling cornered, they were willing to take more drastic measures against any party involved in labor disputes, regardless of gender. Along the way they would have to deny, erase, and re-write the story Camas told about itself as protective of its own. Instead, politicians and businessmen tussled over defining "order" and "disorder," "protection" and "discipline," each daring the other to hold its ground.

The company, councilmembers, and prominent businessmen demanded the Mayor and Chief of Police repress the strike and stop the picketing. Their calls fell on deaf ears. The Mayor insisted the town was at peace and "and absolutely no acts of violence [had] occurred," rebuking the businessmen's allegations of violence in the streets and insisting the strike needed to run its course without interference. ${ }^{34}$ Frustrated, the Camas Commercial Club ordered a message sent to Clark County Sheriff Elbert "Bert" Biesecker requesting action. Not long after receiving the message, Biesecker and newly appointed wartime deputies descended on the city of Camas. Many sheriffs across the nation felt threats to the country and seditious actions were pressing upon them and their communities. The world was at war and alien enemies were all around. Nonetheless, the

34 “Trouble a Minus Quantity,” Oregon Labor Press (Portland, OR), November 10, 1917. 
willingness of outside officers to respond at the behest of private citizens rent the script of the "labor village" in Camas. Soon after his arrival in late early November of 1917, Biesecker began work clearing the streets of Camas and making arrests. On Friday, November $3^{\text {rd }}, 1917$, one of Biesecker's men, Tom Vessey, a constable from Vancouver, arrested six women on strike. The arrests were in response to allegations of assault against a woman, Hattie Turner. Turner, a bag factory worker, remained on the job rather than join the union, and claimed six union "girls" from the picket accosted her. A report in The Camas Post stated "that the girl pickets trailed her to her home on Second Street, and that they used abusive and unseemly language. ${ }^{35}$ The local paper made point to list all of the names of the union women arrested and from records and it appears that one of the women on the current picket line, Alma Hull, had been a participant in the 1913 bag factory strike. The language of "girls" was once again used to insult and diminish the efforts of these women. From census records it appears that all of the women arrested were in their early 20 s. None were below the age of 18 . The media effect was to embarrass if not outright libel women who dared to use their voices in an unladylike ("unseemly") way (at least according to authorities).

On December $29^{\text {th }}, 1917$ a picket formed at the entrance of the paper mill in Camas, just as it had daily for the last two months. The wives of striking male workers also joined the strikers on the lines. The Labor Press noted that they were "doing splendid work and deserve special praise for their efforts" in deterring strikebreakers from crossing the lines. ${ }^{36}$ Their work was noticed by the county law enforcement and in the arrests, and women were now fair game. That day several additional Camas women

\footnotetext{
35 "Six Girl Strikers Put Under Arrest," The Camas Post (Camas, WA), November 30, 1917.

36 "The Strike at Camas," Oregon Labor Press (Portland, OR), December 8, 1917.
} 
were taken into custody. The most prominent of the women arrested was Meta Frampton, wife of Frank Frampton, the president of the IBPM Local in Camas. She was taken from the picket line without a scuffle. By making an example of Frampton, the company and business leaders challenged the mayor to defend his appointees, and, by extension, protect "his" women. While Frampton was fighting her arrest charges from Crown, she and five other women, all wives of striking workers, were appointed as special police officers in the city. ${ }^{37}$ Here Clark waged, via female participation in his administration, his own war of legitimacy over police power. The company, undeterred, identified one of Frampton's fellow deputies, Lutie Smith, for arrest. ${ }^{38}$ A few men were also arrested in the incident. But, the media coverage and litigation centered on Meta Frampton. In other words, a struggle for legitimate police power in the public sphere was literally being played out on women's bodies and their political place in Camas.

The charge levied against Frampton and the women and men on the picket line was unlawful assembly. ${ }^{39}$ This charge that was difficult to either prove or disprove, as it essentially was an accusation of intent to incite violence or to disrupt the peace; that is, the intent, not the act. From the perspective of local labor, Biesecker's actions overstepped his authority and they deemed the charges to be trumped up. Given the thinly veiled behavior of Crown and the equally self-interested moxie of Mayor Clark, the workers felt confident that Frampton and others would not be convicted. They expected that Frampton would be acquitted and the other trials quickly dismissed and publically

\footnotetext{
${ }^{37}$ Mrs. Lutie Smith, Mrs. G.A. Hull, Mrs. R.C. Russell, Mrs. N.D. Bauman and Mrs. F.D. Champlin

38 "Strike Situation in Camas" Oregon Labor Press (Portland, OR), January 19, 1918.

39 “Another Legal Farce,” Oregon Labor Press (Portland, OR), March 9, 1918.
} 
ridiculed, with the entire incident redounding to the union's favor. Their confidence was proven incorrect. The Oregon Labor Press disparagingly reported:

On February $20^{\text {th }}, 1918$ Meta Frampton and, and one other defendant, Mervena Reed, wife of Arthur Reed the vice-president of the papermakers union plead not guilty. Once the jury was selected and the trial was set local labor focused on the fact that there were three women jurors in the case believing this would create a sympathetic jury. All the other defendants demanded separate trials. However, four days later Frampton was convicted of unlawful assembly. The labor leaders and local media was shocked by the verdict. Incensed Oregon Labor Press declared the trial a legal farce. The paper reported the trial occupied four days, and the jury was out more than five hours before reaching an agreement. The verdict was a surprise to those who followed the trial, and perhaps even to the district attorney who prosecuted the case. ${ }^{40}$

Frampton continued to fight the charges on appeal, but from existing records it appears her defense never gained traction. It was notable though, that in court documents, the name William S. U'ren, prominent Oregon lawyer and father of the Oregon Plan, appears on her defense team. Various parties involved sought to use the local justice system to make an example of Frampton in their own interest. This is supported by the fact that the other defendants' cases were dismissed quickly after the first trial. ${ }^{41}$ The Labor Press's characterization of the jurors as "farmers" suggests a rift in the stories-that-could-be-told about Clark County: rural folk operating with one moral economy, industrial workers with another. The strikers felt the "farmer jury rendered the verdict and the only way it can be explained is that the strike and not Mrs. Frampton was on trial before the jury that was prejudiced against organized labor.” They implied that the rural farmers did not understand the workers efforts in the strike and gave a verdict based on bias or ignorance.

\footnotetext{
40 “Another Legal Farce," Oregon Labor Press (Portland, OR), March 9, 1918.

${ }^{41}$ Case 1255, Washington State v. Meta Frampton, March 5, 1918.
} 
The one contention they do not make, surprisingly, is any indication of gendered bias or assumptions from the jury. The decision from the jury was seen as purely anti-labor.

Yet it seems that Frampton's position of power was an affront to the acceptable gender roles to some in power in Camas and Clark County. This is evident in the actions of the Camas Commercial Club in a reported filed:

A number of deputy sheriffs were sent from Vancouver and several arrests were made for unlawful assemblies. Picketing was stopped and conditions were quiet for a time until last week, when five women who had been active in labor disturbances were appointed as deputy marshals. A storm of protest followed this action and a determination to take a decided stand in the matter resulted in a meeting of the Camas Commercial Club in special session. The club organized and financed the movement for recall [of Mayor Oliver T. Clark.$^{42}$

As a result, Frampton's placement as an officer of the law and her conviction sent a message to all the women challenging the status quo coveted by the company and business leaders of the city. Crown decided to punish them directly; then the company determined to punish Clark. Their backlash was not limited to Frampton and the court of law. Crown now reached into the community, like schools, seeking out examples among Camas women aligned with radical politics or other suspicious activities. As "preparedness" and anti-German sentiment caught on regionally, the war effort trumped challenges posed by women actively and publicly aligned with the patriotic fervor of the nation and spoke their minds and defended themselves.

In March of 1918, Emma Roth, an algebra and German language teacher at Camas High School, and new to the town, was dismissed, accused of "spreading seditious pro-German sentiments in her classroom. ${ }^{43}$ Roth was quoted as stating:

\footnotetext{
42 "Camas Recall Filed," The Oregonian (Portland, OR), January 21, 1918.

43 "Disloyal Teacher Quits," Oregonian, February 13, 1918.
} 
What difference does it make to you whether Germany or the United States wins this war? If Germany conquers, the only difference is you will be ruled by the Kaiser instead of the U.S. Government, and the German government is just as good as the U.S. anyway. ${ }^{44}$

Then in May of that year, Mrs. Susan Hodges, a local widow sixty years of age, was placed under arrest and charged with sedition because of alleged remarks made against the American Red Cross and the United States government. She was held without bail. A report in The Oregonian noted that Hodges allegedly "declared she was pro-German, that she hoped there would be a revolution in America and if there was one, she would take up arms against the United States. $" 45$ In other words, it is possible that county law enforcement and Camas leadership used arrests and the media to stir up a competing set of anxieties among the populous, as both a distraction and as a way to shift the conversation and reframe it ideologically.

Nevertheless, the actions and words of these women brought the elements of gender into the realms of media, economics, and politics in a moment when the traditional order of the Camas, the order of the "labor village," was on the defensive. The company, business interests, and outside law enforcement faced new economic and political changes. The participation of women in this movement only compounded anxiety and uncertainty. Economic and political challenges were disquieting but the change in gender and social norms acted as the final straw, as it cut to the heart of protective ideology. When no one could speak for or control womenfolk under the mantle of "protection," it ironically paved the way for harsher power politics along stark class lines. When the men of Camas could no longer chuckle together over girls rolling one of

\footnotetext{
44 "Teacher is Charged with Seditious Talk," The Camas Post (Camas, WA), February 15, 1918. 45 "Women Declared Pro-Hun," Oregonian, May 26, 1918.
} 
their members in the mud as a one-off, the stakes were effectively raised for everyone, especially in wartime. If Camas was endangered by elderly widows and local school marms, then the world was upside down and had to be righted. If Camas was no longer the place where "we take care of ourselves" then the way was made for outsiders, at the behest of the most powerful, to enforce order, top down. 


\section{Chapter II:}

\section{Tempest of Organization: The Strikes of 1916-1918}

The strike of 1913 encouraged workers in Camas to push back against the mill management and vie for a voice in the workplace. By 1916, a supportive environment for labor flourished in the city through the new pro-labor city administration. Even with their bolstered support, the mill workers refused, in the end, to take actions perceived as militant or radical. This stance led to the eventual defeat of the union. Instead, they endorsed the traditional story Camas told about itself, as a quiet, "we take care of our own" sort of community. Compared to Seattle, worker leaders in Camas did not catch the fire of political ambitions or social innovation to demand revolution. Nonetheless, the subsequent strikes created a pivot point socially and culturally for labor and radical politics in the state.

The WSFL settled for legislative success by proxy by electing opportunistic "friends of labor" rather than grow its own political base, and therefore lost ground in town, on the shop floor, and in the legislature. With the outbreak of war, progressive politicians' support of labor legislation receded, and the stagnant Washington economy caught up with the WSFL, whose membership waned. ${ }^{1}$ The locals created in Camas witnessed immense growth and then a dramatic loss of membership within a two-year period. Union and radical movements crested and then receded in Washington State after the events reached a controversial high-water mark in the Seattle General Strike of 1919. The strike "left an ambivalent legacy. The failure of such a massive action to raise shipyard wages -- let alone ward off the union-busting and red-hunting that followed --

${ }^{1}$ Jonathan Dembo, An Historical Bibliography of Washington State Labor and Laboring Classes (Pacific Northwest Labor History Association, 1978), 128. 
showed the limits of local labor's power against state-supported, anti-union capital."2 A few gasps escaped from the lips of labor in Seattle, but by the mid-1920s labor organizing in the state was completely hamstrung until the passage of the Wagner Act.

Through aware of progress for labor and the support for labor's efforts from leftist politicians statewide, the Camas workers that went on strike in 1916 remained tentative in their drive for organization. The paternalistic bonds between the company and town government remained strong. Long-time Republican Mayor Hugh McMasters controlled the administrative seat of power and law enforcement of the town. Camas workers' memory of the first conflict with the mills management in 1913 remained but still no murmurs of organization were uttered. The city administration had always been closely tied to the interests of the mill and the executive and police forces of the city, post-Clark, curbed any dispute with the company. For example, council member John Blair was an employee of the mill. Former mayor James Duvall was the manager of the bag factory. Managers and workers of the mill before, during, and after 1916 filled civic positions in the city.

Thus, the intimacy of small town life posed both opportunities and challenges. The closeness of relationships, the face-to-face quality of life that shaped the moral economy of the "just wage," and an ethos of self-sufficiency and mutuality facilitated adjustments and accommodations, as the women proved in 1913. However, when these conditions were overheated by ideology and war, and a shift in gender privilege, male workers found it harder to gain a foothold. Union leaders hesitated to test the delicate balance of the town's moral economy or the ethos of the "labor village" in confrontations with

2 "Seattle General Strike," accessed June 26, 2015, https://depts.washington.edu/labhist/strike/gold.shtml; Frank, Purchasing Power. 
management, aware that their employment dependency kept them vulnerable. Thus it proved impossible for them to turn the women's advance into a new political environment for a fuller confrontation with corporate power in 1916. Moreover, unlike Lawrence, where middle class allies as well as the International left came in large force to push labor's cause, especially in the media, Camas mill workers remained relatively isolated with only homegrown elements of the left available to aid their fight. Crown was all too willing to paint even these individuals as "outsiders" and dispatch them accordingly.

The strikes of 1916,1917 , and 1918 potentially weakened the historic paternal order in Camas between the company and town. Crown eventually was forced to blame radical outsiders for poisoning the environment and leaving them no choice but to crack down, but workers themselves told a different story. Worker political developmenteducation, training, solidarity — did not move quickly or deeply enough to overcome the traditional ideological divide between craft and industrial workers, and enthusiasm for the hard work of organizing was hard to come by. Instead, the more familiar and perhaps comforting message of the AFL kept Camas and Oregon City workers organized along strict craft lines and politically tentative. Their alignment with AFL craft unionism, which possessed a conservative to moderate disposition in labor disputes, allowed large numbers of newly organized workers to peel away after the removal of the Socialist administration in Camas and the protraction of the strike by the company extended the striker beyond their means to remain out with wages. Both in 1913 and 1916 momentum to organize was present but the leadership chose not to build on it. It is impossible to say if organization had come earlier whether the narrative would have changed. As war 
loomed, the environment in which labor functioned was increasingly hostile and unfavorable.

The year 1916 brought the tensions of "preparedness" felt in many sections of the country home to Camas. Frustrated by the continued poor wages and conditions at the mill at a moment when industry stood to profit from wartime production, the workers at the Camas mill challenged the mill for improved conditions and better wages. In early 1916, the workers asked for an increase of wages. The company responded, granting "a 10 per cent increase in wages all along lines." Sensing a sea change in management's willingness to come to the table and possibly acknowledge a union, workers regrouped and insisted that the raise was not sufficient. ${ }^{3}$ The Socialist party had developed allies in Camas; and two organizers, Oliver T. Clark and Kelley Loe, worked to shift political environment in favor of labor. For example, Carl Ulonska, Secretary-Treasurer of the Washington State Socialist party, came to speak in Camas just after the strike was underway. His speech was titled "Feed America First," and the handbill advertised "a message for you that will make YOU think and act." ${ }^{{ }^{4}}$ In early May of 1916, the workers in the finishing room walked out. According to The Oregonian and The Camas Post, eighty men in total walked out. Their demands were an increase in wages from $\$ 2.00$ a day to $\$ 2.50$. Just as the women of 1913 , these workers were not organized and made no request to form a recognized organ of negotiation.

The mill's management at this time, unlike in 1913, planted the seeds for the later policy of refusing to formally negotiate with any collective body of workers at the mill. This was neither here-nor-there for the strikers; the focus of the strike was short-term

\footnotetext{
3 "Agree to Arbitrate their Differences," The Camas Post (Camas, WA), May 19, 1916.

4 "Carl Ulonska" The Camas Post (Camas, WA), May 19, 1916.
} 
gains and only slight indications of organization were present. Lewthwaite, now resident manager of the Crown-Willamette mills in Camas and Oregon City, was away in the East conducting company business. The company refused to even consider formal negotiations until the return of the manager. Crown's leadership remained opposed to the principle of unionism. Their involvement with the National Association of Manufactures, which strongly supported open shop and non-negotiation with union policies entrenched and fortified their anti-union stance.

The spirit of neighborliness in Camas did surface, however, in a surprising spontaneous public debate about mill conditions on the evening of May 3, 1916. Somehow, the tension had to be relieved. Since union officials did not step up, parties to the spontaneous walk out met out in the tennis courts in town. The strength of the ethos of the "labor village" permitted both management and labor to address their grievances before the public. On the evening of the walk out, a spontaneous mass meeting was held at the tennis courts on Fifth Street in downtown Camas. At this meeting, Joseph S. McAllister, local businessman and future Socialist city council member, spoke on the behalf of the laborers. Speaking for the mill was a manager named McBain. McAllister and McBain did not address each other in direct dialogue, as they might in a partisan political debate. Rather, the tone of evangelism surfaced with the goal to convert public opinion from the mass of citizens attending to one side or the other. Rather than seek a settlement behind closed doors, both labor and the company chose to take their case directly to the people. While emotions were vented and validated, no concrete resolution 
or progress came at the tennis court meeting. Ultimately, the delay in formal negotiations initiated the progressive shutdown of operations at the mill by management. ${ }^{5}$

From media reports, management created the image of workers "idling" the mill. In articles about the strike, vaguely threatening statements, such as "the tie-up will soon affect other parts of the mill as well" and "Two of the largest machines already are down as a result of it and others are expected to go down tonight" were made and implied the cause of the shutdown was the workers. ${ }^{6}$ After one day of stoppage, Crown acted in violation of the status quo of the "labor village" by importing finishing room workers from their Oregon City mill in as replacements, which raised the ire of workers not already involved in the walk out. On May 13, an additional four hundred employees walked out in protest of the company's efforts to break the strike. Around the same time the company's sawmill and bag factory in town both shut down. The only remaining components of the mill still in operation were a few paper machines running "until the stock [was] used."7 Crown estimated soon the entire mill would go idle. Management's resolve to avoid negotiations cracked as a result of workers successfully engagement in a stoppage. A meeting between a strike committee and management was arranged but produced no results. Crown scrounged up a few employees to create the appearance of functioning: only a skeleton crew of management and some engineers remained at the mill.

Sensing the moment for building solidarity, millworkers shot back at the company by going beyond the boundaries of the town. By May 13, when several hundred more

\footnotetext{
5 “Paper Mill Hands Strike," The Morning Oregonian, May 3, 1916.

${ }^{6}$ Ibid.

7 “Paper Makers Walk Out at Camas Mill," Bellingham Herald (Bellingham, WA), May 13, 1916.
} 
workers walked out, "a committee of strikers [from Camas] went to Oregon City to induce a walkout at the Crown-Willamette mill there." They hoped to apply more pressure on the company to concede and settle. ${ }^{8}$ The intention of the Camas workers was to unify the Crown-Willamette workers across mills and cripple the company at its two largest operations. With little planning beforehand, they simply assumed their fellows in Oregon City would lend them sympathy and support. To their surprise, the workers of Oregon City were not prepared to join Camas in its efforts. The workers of Camas who sought greater agency through solidarity with their fellow workers at other CrownWillamette mills miscalculated. The Camas "labor village" tradition of personal, face-toface relations did not translate to Oregon City at this time, and rather than organizing beyond town borders and they remained along local and industry lines.

After 17 days of successful work stoppage, some critics in the media described the workers' energy as 'flagging." As far as mainstream news reports went, workers were portrayed as submitting to management's original offer. Though the record is scant, it seems that work stoppage effectively broke down Crown's stonewall tactic. Lewthwaite came to the table and met with the strike committee. On May 19, 1916, an agreement was reached about wages. All employees of the mill received a nearly ten percent wage increase. The general mill laborers' wages were raised to $\$ 2.40$ per day while skilled workers received $\$ 3.30$ per day. The papermakers and machine tenders were bumped up to $\$ 3.68$ to $\$ 5.25$ per day. However, the distribution of the wage rate for the majority of the workers remained at the lower end of the overall spectrum industry-wide. But the strike was settled and the citizens of Camas once again saw smoke rising from the mill's

\footnotetext{
${ }^{8}$ Ibid.
} 
chimneystacks, a sign that the community's economy once again flowed. ${ }^{9}$ Without the backing of their fellow workers in Oregon City and strong community support, the strike was ineffectual beyond piecemeal change. In order to achieve a real union, workers needed a stronger base of solidarity and support within the city. Given the burn out rate of spontaneous walkouts, Camas workers learned a lesson: that a strong union, well aligned with the local government, was necessary to succeed in consistently gaining fair wages, hours, and conditions at the plant. However, a union, an organized body in opposition to management, meant that the spontaneity and mutuality of neighbors solving their own problems together might be eroding, changing the traditions of the "labor village" with the belief in face-to-face resolutions.

Given the factions between craft and industrial unionism in the state, Camas workers possessed no ready models at hand. Combined with additional pressure exerted on labor by political leftists within the movement, the strikers knew a nascent union in Camas had to make a difficult choice between craft or industrial unionism. The strike committee called a mass meeting at the Camas Opera House and engaged in a lengthy discussion about unionization. Clearly, people were interested in hearing new ideas. On Saturday, May 13 at 2:30 pm, some 500 workers from the mill filed in for a discussion. Charles Frampton, a paper maker and future local president, brought to the group's attention the quandary of alignment. Then, Frampton "pointed out the complex nature which might be encountered in attempting to organize several different classes of labor

\footnotetext{
${ }^{9}$ W.R. Smith Report to the National War Labor Board "Index to National War Labor Board Records, April 1918-August 1919" (Department of Labor, n.d.), 2-3, Records of the National War Labor Board (World War I), 1918 - 1919, Record Group 2, (Crown Willamette) Docket 9, National Archives at College Park, MD.
} 
unions under one head." ${ }^{10}$ This moderate tone and reticence from Frampton was notable compared with the untapped and feisty groups of workers who were willing to walk off the job to press their point directly with managers.

The company, for their part, was willing to paint the workers as ignorant of the intricacies of the economy. As in the tennis court discussion, both workers and company officials were present in the Opera House. Mill manager from Oregon City B.T. McBain and superintendent Philip J. Lamoureux claimed the company simply did not have the money to meet the full demands of the workers. ${ }^{11}$ McBain's position was essentially denial and crying poverty, explaining that "the method in getting the commercial product of the mills on the market, very often under contract" with the purchasers set the price of production - wages, benefits, new facilities, etc. - long in advance. ${ }^{12}$ The foundation of paternalistic rhetoric was evident in McBain's statements. He assumed that the striking workers needed the company to explain how the economy worked and was quick to point up the unreasonable and ignorant nature of their demands. Workers were expected to accept the story that wage setting was not the fault of the company but the result of a system beyond management's control. However, the workers understood the system and its inequity and supported those willing to reform it, if not in the union movement, then in the electoral realm.

Time to Strike: The Strike of April 1917 and the Formation of Locals

\footnotetext{
10 "Agree to Arbitrate their Differences."

${ }^{11}$ Philip J Lamoureux, wife Rose, Arthur C Lamoureux machinists at the mill, wife Kathleen, Beatrice Lamoureux. All lived in Camas at this time. McBain, Bankus, and Lewthwaite did not they lived in West Linn and Portland.

12 "Agree to Arbitrate their Differences."
} 
Reeling from the ineffective strike of 1916, those interested in organizing and fighting mill management again knew something had to change in the city. In January of 1917 that change came with the election of Oliver T. Clark as Mayor. Now with a declared socialist and laborer from their ranks in the paramount seat of power in the city, the rank and file mill workers were poised to make a move. In April 1917, they once again walked out on strike. This time the workers looked to gain full concessions from the mill management and ensure the creation of an organization able to acquire future demands of management. With a portion of the city leadership squarely in their favor, the hand of the workers was strengthened. Ambitious leadership acknowledged in the Paper Makers' Journal that "Oregon City and Camas...[have been] an eye sore in the paper making world for a long time on account of not being organized." Now they warned their fellow paper makers across the nation to "rest assured" about the imminent establishment of two Locals in Oregon City and Camas. ${ }^{13}$

For their part, Crown also retooled their approach. Over the course of the previous year, the company had worked to head off labor actions with small reforms. They established the impression of equitable work shifts with the creation of a three-shift arrangement and the promise of limited work on Sundays. However, the list of grievances by the workers was long. The majority of the workers at the mill had to work long hours and never enjoyed the benefit of the shifts or days off. It was noted that "about $50 \%$ of the employes (sic) worked nine hours per day, and were termed day workers. This class of workers was not subject to shift work, and received the lowest wage...in [the]

\footnotetext{
${ }^{13}$ The Paper and Pulp Makers' Journal, vol. 16 (Albany, NY: International Brotherhood of Paper and Pulp
} Makers, 1917), 19. 
schedule. ${ }^{14}$ Furthermore, all workers regardless of their shift received no breaks or time for lunch. The management made many promises that yielded slim results in actual conditions for the mill workers. The mill essentially ran seven days a week. The fight over Sunday work had been raised in the previous strikes and tacitly won, yet, maintenance of the paper machines, new wiring, and any other repair work was still conducted Sundays. The mill workers were amenable to work on Sunday if an emergency arose or if it was absolutely necessary for the good of the plant. Conversely, management made it a routine to have work shifts on Sundays and by 6 am on Monday mornings the full operation of the mill had resumed. ${ }^{15}$ In years prior, efforts against Sunday work spread through American industry. One of the nation's largest employers, U.S. Steel, limited Sunday work and, as a result, this brought to the attention of the United States government and public the question whether Sunday work was an abusive and oppressive practice and was needed any longer. ${ }^{16}$

Given that the veil of face-to-face dealings between workers and management was now tattered almost beyond recognition, Camas workers confronted their lack of power even more starkly. With their newly gained civic support, the workers knew the time was right to strike. Approximately seventy-five workers comprising "nearly all departments of the mill" walked out on strike at the mill at 1:00 pm on April 16, 1917. ${ }^{17}$ The Oregonian reported that, "a statement was presented to mill officials [in which]...an increase of 50 cents per day flat was asked, with time and a half for overtime and double

\footnotetext{
14 "Index to National War Labor Board Records, April 1918-August 1919," 2.

${ }^{15}$ W.R. Smith report to National War Labor Board "Index to National War Labor Board Records, April 1918-August 1919," 3.

${ }^{16}$ Joseph P Goldberg and William T Moye, "The First Hundred Years of the Bureau of Labor Statistics," U.S. Department of Labor Bulletin 2235 (September 1985): 53-55.

${ }^{17}$ Oregonian, "75 Paper Mill Men Quit,” April 17, 1917.
} 
time for Sunday work." The wages at the mill had remained at " $\$ 2.40$, the lowest for 10 hours, to $\$ 2.75 .{ }^{\prime 18}$ These demands and the walkout followed a 5\% raise granted to the employees earlier that same month. Insufficient for the workers, they believed that the time was right to push for more by striking. Management was prepared, however. Albert Bankus, the local manager of the mill, "a few minutes after 1 o'clock...made out [the time] for each man who failed to resume work... and [stated] that new men be secured to fill their place." ${ }^{\prime 19}$ Bankus ducked worker demands by declaring them unreasonable. However, this old ruse only encouraged more workers to walkout. By the day's end, only one division of the mill remained open; ironically, it was the bag factory.

The company's effort to shape the impression and memory of the strike surfaced in the specific attention paid by pro-company media that "no employee of the bag division was among the strikers." The division that had given the mill so much trouble in 1913 and was primarily staffed by women from the city did not participant in this strike. For its part, the A.F.L affiliated unions consistently reined in female voices, the locals in Camas were no different. The pivotal role the women of camas played in 1913 starting the labor movement in the city was ignored. For the duration of the strike to come, women served peripheral roles in direct negotiations, but imbued moral support walking the picket lines and political encouragement in short-lived but significant civic positions.

Crown manipulated the "good" (female) non-striking workers against the "bad" (male) strikers. Good workers worked and got paid; bad workers refused to work and were accordingly punished. One day after the start of the strike and the threats made by Bankus, the mill "posted notices at 7 o'clock that the mill would remain closed

\footnotetext{
${ }^{18}$ Ibid.

${ }^{19} \mathrm{Ibid}$.
} 
indefinitely," save for the bag division. ${ }^{20}$ By this time, nearly five hundred workers were on strike, a larger number than in all previous strikes. Unified and vitalized, more mill workers caught the fever for unionization. The mill workers began to hold "meetings...to perfect an organization, which they hope[d] to affiliate with the Papermaker's Union of America." ${ }^{21}$ AFL affiliated locals of the IBPM and PPSW were established. Each new Local was created along craft lines with individual leadership, needs, and demands. The Locals then formed a negotiating committee and submitted their formal demands. Crown unequivocally refused to recognize the new organizations. Crown's management immediately and emphatically "opposed [the] unionization and [exerted] every effort to stamp out the union." 22 The pressing matter of the mill being shut down weighed on the management; however, Crown held fast to its strict policy of not relinquishing agency over the operations to the workers was developed. By denying the legitimate organizing, Crown sought to shut off any other reality. They needed to shape the "labor village" discourse by framing the "unreasonable" strikers as the "cause" of no wages going into families' pockets.

Camas, the "labor village," was not fooled. They saw through the lockout for what it was: punishing behavior against workers who needed to survive and had a legitimate right to petition to be heard if not a statutory "right" to organize. After three days, the management of the mill relented to the demands of the workers. Camas working people knew that if wages stopped, so, too, did profits. If Crown eroded its relationships with the laboring community by the lockout, so too were its relations with business

\footnotetext{
20 "Camas Mill Closes Down," The Oregonian (Portland, OR), April 18, 1917.

${ }^{21}$ Ibid.

${ }^{22}$ Report of President Wilson's Mediation Commission," Index to National War Labor Board Records, April 1918-August 1919, 8.
} 
partners and contracts jeopardized by the stoppage in the mills. The result was a raise for workers:

of 50c a day to the men previously getting $\$ 2.40$, and $25 \mathrm{c}$ a day rise for the $\$ 5$-a-day men, with a sliding proportionate scale fixing increase for those receiving wages between the two sums. The men receiving over $\$ 5$ a day were given a 5 per cent increase. The eight-hour day and the overtime considerations were not granted. ${ }^{23}$

As in 1913, Crown framed the settlement in terms that maintained the perception of their full control and power. The mill's management started a campaign in the local papers of the state to the effect that Crown put into effect its own - rather than workers'-plan for wage increases. Manager Bankus stated:

The company at the time, and even prior to the walkout, was preparing a pro rata schedule which they intended to put into effect for the whole of this month, and which would cover all the higher wage demands of the men. ${ }^{24}$

Bankus wanted the public to know the unnecessary, "unreasonable" nature of the strike. In his words, if the workers had waited, management was already prepared to give them the increased wages desired. The company, with this statement, increased the degree of epistemological violence against the workers, sticking to its policy of denial. The mill's management desired to mitigate the view publically that the strike was a success and maintain the impression they held the power in the relationship. Furthermore, the company needed to continue the narrative that the workers did not understand the larger working of the company and economy. It was implied in his statement that the workers efforts came from a place of ignorance. They had a surprisingly easy time of using local elite media outlets to get their version of events into circulation.

23 "Camas Strike Settled" The Oregonian (Portland, OR), April 22, 1917.

${ }^{24}$ Albert Bankus quoted in The Oregonian "Camas Strike Settled," April 22, 1917. 
The success of the unionization drive prompted Bankus and the other managers to diminish the success of the strike and the overall efforts of the workers to organize. The Locals affiliated with the AFL, and, at the end of the strike, the PPSW, was already nearly three hundred and sixty members strong. A new power dynamic in the town developed in which workers and management now both had economic knowledge and media savvy pointed at questions of economy. The inequity of power in which formal messages to the public came only from the company shifted; now the workers had an organized voice. Management ardently endeavored to avoid recognizing the new organization though Crown remained invested in the village ethos of engaging in the public life of Camas. As long as this engagement did not broach the harder-edged economic sphere, touching profits and contracts, management worked with the new organizations. ${ }^{25}$

Though labor historians note that in this period unionization created power, in the case of Camas power created unionization. In April of 1917, the new Locals of the PPSW and IBPM were established in Camas. By June, the workers of the newly formed Papermaker's Union proudly announced themselves to their fellow union brothers. Their address explained the recent events and the genesis of their organizing. The members of the new union explained that they felt compelled to unionize not because of wages, but "to protect [themselves] against unforeseen troubles," and "on the $17^{\text {th }}$ of April about forty men met in a Brother's basement and proceeded to organize a Local." ${ }^{26}$ By this time, the Papermaker's Local (PML) had amassed nearly 110 members and the PPSW

\footnotetext{
${ }^{25}$ Ibid.

${ }^{26}$ The Paper Makers Journal, 19.
} 
was over 400 strong. ${ }^{27}$ The new unions continued to grow in strength and confidence over the next month. The year 1917 represented a modernizing moment for paper mill workers: the new village, the new loyalty, and the new citizenship was the village of labor, not the locale of Camas or Oregon City.

The Papermakers of Camas boasted joyfully in a correspondence in their national publication that they were continuing to gain ground. The new union moved the conversation beyond the limits and discourse of the town, a key transition from the local moral economy to the entrance of a larger discourse tied into national discussions. They bragged that they had "got a $\$ .50$ flat raise without thrashing and also one hour later on Monday morning start ups," crediting the strength of their union standing behind them. ${ }^{28}$ The union was strong and officers were being put into their place to manage the organization's growth and negotiations. Frank Frampton was elected president of the local; and in October of that year, he and his wife played a noteworthy role in the unfolding labor dispute. The Camas contingent ended with some personal notes about what its members were doing, none of this work or union related. However, a correspondent from the national arm of the union took the time to discuss what the incorporation of Camas meant and the horizon for their next organization.

A noted before, Camas "had been an eye sore in the paper making world for a long time on account of not being organized," and newly elected officers made much of this conversion, this birth into a new domain. ${ }^{29}$ News and excitement spread to the Crown-Willamette mill in Oregon City, which had previously been a point of shame, but

\footnotetext{
${ }^{27} \mathrm{Ibid}$.

${ }^{28}$ Ibid., 19.

${ }^{29}$ Ibid., 19.
} 
now joined the organizational ranks. Workers from the Oregon City mill had requested the national arm of the union to come out to their city "so as to...encourage them along with their organizing." ${ }^{30}$ However, this seemed to be a moot point, since they were inspired by events in Camas. The citizens and workers of Oregon City were already amassing in meeting to discuss unionization. One exuberant report stated that a mass meeting of 1,110 discussed the union proposition, of which nearly all were in favor. ${ }^{31}$ The mass meeting shifted the village's face-to-face accountability to the union hall and shop floor, creating a new village of labor. The national arm of the Papermakers was certain that a Local rose in Oregon City and its employees held the Crown-Willamette Company to task. They were correct, and in a matter of months Camas and Oregon City were both organized and had elected officers.

Reaction quickly set in, however. Soon after their formation "the newly elected presidents of the Paper Makers' Union, and others, were...called before their employers and told that unless they dropped their membership in the unions there would be discharges." 32 Crown turned up the heat with patriotic and nationalist rhetoric with "nearly every... attack made upon the strikers [being] made under the guise of patriotism."33

This rhetoric effectively reframed the public discourse, from village, to union, to nation. Labor had to keep up. Leaders of the Locals framed the warning and threats from

\footnotetext{
${ }^{30}$ Ibid., 19.

${ }^{31}$ W.R. Smith, 3.

${ }^{32}$ Ibid., 3.

${ }^{33}$ W.R. Smith and National War Labor Board, "In the Matter of the Strike of the International Brotherhood of Paper Makers, the International Brotherhood of Pulp Sulphite and Paper Mill Workers and the International Association of Machinists. In the Mills of the Crown-Willamette Paper Company at Camas Washington Oregon City and Lebanon Oregon and the Hawley Pulp and Paper Company at Oregon City Oregon" (Washington D.C.: National War Labor Board, August 3, 1918), 17-19.
} 
the Company as an infringement on their freedoms as Americans. The officers of the new Locals did not heed the warning, but rather sent a warning of their own to the management of both Crown Willamette mills in Camas and Oregon City. They "informed their employers that the right to join a labor organization, a church, a lodge, or any order that was considered lawful and proper by [the] government could not and would not be conceded, and insisted on their right to continue unmolested in their effort to organize." ${ }^{34}$ Reprisals set in. Crown Willamette discharged Roy Ott, president of the Paper Makers' Union, and mill workers at the Oregon City mill. Furthermore the company stated "to others that they too would soon be discharged." ${ }^{35}$ Neither the Union nor the Company relented and a lengthy and violent labor dispute was on the horizon. ${ }^{36}$ At this time, the officers of the Paper Makers' Union solicited the help of the Oregon State Federation of Labor to get Ott reinstated and help change the conditions at the mill. The management was unresponsive, yet, still the paper makers wanted to avoid a strike. Workers in both Camas and Oregon City held out hope for a peaceful resolution to the struggle with no interruption in production at the mill. For a short period of time, regardless of the actions of the management and the building tension, the workers and the mill remained amenable and communicative.

\section{Calm Before the Storm: The First Labor Day in Camas}

In the face of the war in Europe, labor and business leadership in Camas held their fire, and peacefully co-existed during the summer of 1917. In early September of 1917, all seemed to want to espouse peace between labor and management at the Crown

\footnotetext{
34 "Index to National War Labor Board Records," 3.

${ }^{35}$ W.R. Smith, 3-4.

${ }^{36}$ The Paper Makers Journal, July 1916:19.
} 
Willamette Paper mill and in the city of Camas. The union, with the support of the local people and components of the political establishment, gained strength and notoriety in the community. A season of war production prosperity only helped the cause. The mill was running at full bore and the conflicts of April seemed to be all but forgotten. Together the works, mill, and city of Camas planned and executed a massive, and first ever, Labor Day celebration. Drawing from mixed emotional streams, crowds between 1500 and 2500 flocked to Camas for the event, hoping to give some new meaning to this new social opportunity in the public sphere.

A correspondent from Camas wrote to the Papermakers' Journal extensively about the festivities and spirit of accord felt on that September day. He noted that George Schneider, Vice President of the International Brotherhood of Papermakers, was in attendance. The members of the newly formed Local 130 beamed with pride and enthusiasm. The merriments began with a parade "followed by field sports, then [a] big barbecue," a speech by Schneider. The day was capped with a baseball game between the Camas Inter-City league champions and Red Rupert's all-stars of Portland. ${ }^{37}$ In these rituals of play, patriotic speechifying, and breaking bread together, participants seemed to tolerate the local moral economy's incorporation of a new era of labor-management relations in the "harmony of interests" model. Perhaps smiles were perhaps tense, but there were smiles. Labor, management, and citizens all sat in the Granada Theater and watched workers and management glorified in their daily duties on a projection screen. All embraced their identity as a town centered on the mill. Participants played along in perhaps the best sense: an aspirational faith in shared values of mutuality, love of

${ }^{37}$ The Paper and Pulp Makers' Journal, Vol. 16, (Albany, NY: International Brotherhood of Paper and Pulp Makers, 1917), 12-13. 
country, and the proud, skilled worker identity as paper makers. Crown Willamette Mill Superintendent W.H. Goodenough lent his expertise on the production of paper to the event by giving a lecture on papermaking "and showed...fifty slides of fine grade mills," which included four reels of slides from the local plant. ${ }^{38}$ The local paper, the Post Record, championed the recognition of the Labor Day success. They wrote "the flattering degree of success attending this initial efforts...may be considered a good omen and a criterion by which to judge future events of it's character." 39

\section{Radicalism, Rhetoric, and the Flag}

Despite the Labor Day interlude of public and ritual story-telling about the harmonious mill village, tensions remained from the April strike and grew as the year stretched on. The members of the newly formed unions knew how tenuous their organizations were due to the early failures at organization. Fanned by the factionalism within labor at the state level between craft or industrial unionism, workers began to fear efforts from the company to "stamp out the union." 40 Still without a contract and formal recognition by the company, the Locals' leaders consolidated their demands. On their list of requests were "for 24 hours off on Sunday, time and one-half for Sunday work that is necessary, recognition of the union by the company and the company receive a grievance committee. ${ }^{41}$ High on the list was the much more explosive issue of a closed shop, driven by the need to protect "the union organization." "42 The company rejected this request outright. Quickly a new request was submitted on October 16, 1917, which

\footnotetext{
38 "Camas People Were One on Labor Day," The Camas Post (Camas, WA), September 8, 1917; "Camas Labor Celebrates," The Oregonian (Portland, OR), September 9, 1917.

${ }^{39} \mathrm{Ibid}$.

${ }^{40}$ Wilson's Mediation Commission, 8.

${ }^{41}$ The Paper and Pulp Makers' Journal, 12-13.

${ }^{42}$ Wilson's Mediation Commission, 8.
} 
restated their demands and omitted the question of a closed shop. This omission conceded a point of impasse for the company. The strike committee hoped Crown would be open to the main list of demands without the distraction of the closed shop issue. ${ }^{43}$

With the nation now at war in Europe, Camas contended with several newly bolstered sectors. Not only did new unions press their claims, but the federal government made its presence felt as well. With the demands submitted by the strike committee, the mill's management sat down to consider the proposition. Lewthwaite, along with B.T. McBain from the Oregon City mill and Albert Bankus from the Camas mill met with the workers committee on October 16, 1917. No deal was worked out. As the strike lengthened, Crown had to contend with other observers and stakeholders, notably the National War Labor Board (NWLB). A federal investigator later reported that Crown "would not recognize the union or any committee from the union to adjust grievances or anything else." ${ }^{44}$ Lewthwaite and others perceived the simple existence of the union and the company's acknowledgement of organized workers at the mill as an affront to their rights over their property as management and owners. While managers agreed that workers needed to be patriotic and could acknowledge a certain kind of social "debt" to labor as expressed in the Labor Day Festivities and their piecemeal adjustments to worker demands via previous walkouts, the new ambition of unionization in wartime raised the stakes for all concerned.

Management still defended a strict hierarchy between the workers and the employer, in which the employer included the stockholder, upper management, and supervisors. Crown insisted that employees leave their grievances to the discretion of the

${ }^{43}$ W.R. Smith, 5.

${ }^{44}$ W.R. Smith, 5. 
employer on a person-to-person basis, through foremen and unit managers. Collective action infringed on employer's rights to manage their property, the company, as they saw fit. Both the workers and the employers remained firm in their positions. The workers might be "producers" (and "voters") but the employers were "owners," and stood on the new precipice of a new battle.

By now, the Camas Locals had a structure, a plan, and a process in place to take collective action. On October 20, 1917, the Paper Makers' Union and the Pulp and Sulphite Workers' Union called a meeting and took a strike vote, which passed. Five days later at $4 \mathrm{pm}$ workers walked out on strike. In the preceding hours, state level negotiations attempted to prevent the conflict. The strikers from Camas were joined in their efforts. In coordination with Camas, twelve hundred workers from Crown's Oregon City mill left that afternoon with the intent to stay out on strike. Additionally, the machinists of the mill joined the strike in sympathy, adding no demands, just offering solidarity.

Aware and fearful of the coordinated strike between the mills and the serious economic impact to the region that the strike portended, the Governor of Oregon, appointed the new federal Board of Mediation and Conciliation, stepped in. Oregon Labor Commissioner, O.P. Hoff, and his counterpart from Washington State, C.H. Younger, worked as a part of the commission to bridge the gap between management and the workers. Crown still refused to negotiate. ${ }^{45}$ Furthermore, W.P. Johnson, president of the Crown Willamette, sent a telegram to the two labor commissioners stating that "the company would not enter into an arbitration agreement. The company and the union now

\footnotetext{
${ }^{45}$ Wilson's Mediation Commission, 8.
} 
waged the strike in negotiations and the picket line and additionally in the court of public opinion through local media. Just two days after the strike started, general manager for Crown Willamette in the region, Lewthwaite, told local papers that he estimated that about $75 \%$ of the workers at the mills had walked out on strike and few wanted "to remain out of the work long and may be expected to go back soon." ${ }^{46}$ This was a version of the old self-serving rhetoric that a work stoppage by labor actually hurt workers, and attempted to shift the blame from company policy to union decision makers.

This line of argument appeared again and again, consistently and loudly in media in two states, due to the relentless efforts of the mill's management to control the story for the duration of the strike. Additional rhetoric declared in local media included the company's continued productivity, regardless of the loss of the striking workers. The implication, broadcast far and wide and meant to intimidate and demoralize workers, was that all employees were easily replaceable. Pro-labor publications countered the company's claims of normal production with accusations of a dangerous work environment and descriptions of subpar quality in the paper produced. Labor argued the company was forced to use a barge to "store waste paper that had been returned to them during the winter. ${ }^{״ 77}$ The reality of either claim in difficult to ascertain. However, the passion in which both the company and unions fought in the realm of public opinion lead one to believe that both sides were struggling due to the strike.

To keep their operation running, Crown Willamette attempted to contract out orders. In 1914, Crown Columbia Paper Company merged with the Willamette Pulp and

\footnotetext{
46 "Not All Of Men Quit," The Oregonian (Portland, OR), October 27, 1917.

47 "Strike Situation at Camas," Oregon Labor Press (Portland, OR), April 27, 1918.
} 
Paper Company, forming the Crown Willamette Paper Company. ${ }^{48}$ This proved to be a misstep for Crown and the contractor. They bid out Oregon City and Camas orders to the Hawley Pulp and Paper Company. In the early hours of Friday, October 26, 1917, Crown's order went out to the machines at Hawley and at that point the machinists refused to process it. And as a result, around 600 of Hawley's workers walked out "rather than execute an order from the Crown Willamette concern." ${ }^{39}$ The management of Hawley's was now in a terrible situation. They had lost a significant workforce and had similar concerns about union recognition as a "point of no return" similar to Crown's management. They stated that "the men made no demands upon our company save for the indirect closed shop indication in their refusal to work the Crown Willamette order. We shall execute that order, as should we refuse to it would be an acknowledgement of the closed shop, which we cannot grant." ${ }^{, 50}$ None of the local paper concerns in the region were willing to give any indication of their compliance with a closed shop. They viewed this as a dangerous threat to the sovereignty of their control over their own company. Their position also reflected the possibility that a hiccup in order, production, and delivery, inevitably meant an interruption in the flow of cash and a potential erosion of relationships and business in a volatile wartime economy. Without more assurances either much more unionization or none-it was difficult to leverage the necessary critical mass to make a strike stick in a local economy so entangled with Crown. The mixed condition was a difficult one for labor. Yet, the demands of the workers no longer included a closed shop demand, which seems to indicate that the company knew which

\footnotetext{
48 "Center for Columbia River History - Camas," accessed July 1, 2015, http://www.ccrh.org/comm/camas/millhist.php.

49 "Hawleys to Start," The Oregonian (Portland, OR), October 27, 1917.

${ }^{50}$ Ibid.
} 
narratives worked in their favor and which would work against them. Soon after the dispute and walk out at Hawley's mill, Crown was served another potentially crippling blow to their entire operation in the Northwest.

As in events of 1916, spontaneous worker pressure, rather than the hermetic seal of a closed shop industry, upped the ante for labor. In early November, Oregon City and Camas workers remained out on strike. At that time they were joined in their effort by the last local Crown mill. On November 1, 1917, the workers of the Crown Willamette mill in Lebanon, Oregon walked out. The Labor Press kept tabs on management's shenanigans and reported that Crown, attempting to book a job with the Hawley Paper Company, had sent an order intended for the Camas mill to the Lebanon plant. As a result, the workers refused the order and walkout in solidarity with the workers of the other two mills. ${ }^{51}$ It was estimated that fifty of the hundred workers at the mill went on strike. Even though they were granted "a 20 per cent wage increase... and a 50 cent daily increase...in July," they stood with their fellow workers and walked out. Just as in Camas the mill was the largest industry in the city and the heart of its economy. ${ }^{52}$ Upon notice of this incident, S. Ed. Launer, secretary of the Oregon City local of Pulp, Sulphite, and Millworkers union, headed for the city. ${ }^{53}$

\footnotetext{
51 "Strike Situation at Oregon City and Camas," Oregon Labor Press (Portland, OR), November 10, 1917. 52 "Lebanon Mill Men Strike," Oregonian (Portland, OR), November 2, 1917.

${ }^{53}$ Carl G. Green also came with Launer, It is difficult to find what affiliations Green had with labor at this time. However, it looks like Green was heavily involved in politics in Oregon City. His obituary stated the following: "OREGON CITY---Carl G. Green, 65, a resident for many years, died early Wednesday morning at his home following a heart attack suffered a few minutes earlier. Green, who was born October 5, 1888 to the late W.C. and Della Green, was a life-long resident of Oregon City and had been active in politics all of his adult life. He had worked for the state accident commission for the last 12 years and was a past president of Local 191 for state employees. He had retired just last October." His role is uncertain at this time, however, need to be examined for another potential fold in the narrative.
} 
At this point, labor began its public assault on the company in the media. Both the company and labor engaged in efforts to depict themselves as patriotic Americans and question the other side's devotion to the country. This was a result of the United States recent entry into the World War and the concern over raw materials, labor, and production spreading across the nation. At the same time the workers of Lebanon were going on strike, the Oregon Labor Press $(O L P)$ began both defensive and offensive campaigns regarding the patriotism of the workers and company. Published just a short time after the start of the strike the $O L P$ responded to the speech of two Crown Officials at the dedication of the new school building in West Linn. The speakers used the opportunity to call the strike by the mill workers unpatriotic. The $O L P$ refuted this claim, stating "if cession of work at this time is unpatriotic, is it not unpatriotic for the employers to discharge men for union activities?"54 To drive the point of the union's patriotism the article immediately following stated that J.T. Carey, President of the International Brotherhood of Papermakers, advocated for union purchase of war bonds "in Second Liberty Loan to the amount of ten thousand dollars." 55 The labor press and workers knew the importance of getting this message out and demonstrating their patriotism while questioning that of the company. This set the stage for a battle of ideas, all jockeying around patriotism, which continued for the duration of the strike.

The workers in both Oregon City and Camas formed large picket lines at the workers' entrances to the mills with the goal to dissuade the remaining workers and strikebreakers from continuing with the company. The Labor Press did a brilliant job of

\footnotetext{
54 “Are American Workers Patriotic," Oregon Labor Press (Portland, OR), November 3, 1917. ${ }^{55}$ Ibid.
} 
painting strikebreakers as unpatriotic to the average worker and citizen sacrificing for the war effort:

The blush of shame comes to the face of many of these strikebreakers as they face the worker they are displacing, and it's a wonder that men can be induced to become traitors to the cause of labor. Of one this all unionist are certain, and that is these men have no real conception of what organized labor means and the depths that it has reached in our economic system, or no influence could cause them to do this treasonable act.

In addition, the patriotic rhetoric of the $O L P$ denigrated the strikebreakers as either criminals or rubes.

Due to the displacement of wartime mobilization, unsettled and drifting men became increasingly visible in towns and cities of the Portland -Vancouver region. This situation may have made strikebreakers or temporary and replacement workers more available to Crown. Newspapers reported that the numbers of strikebreakers coming to Camas and Oregon City increased in the fall, perhaps as the harvests wound down and seasonal laborers drifted into town to get work and shelter in the cooler weather. There was speculation that these workers were coming from several different locations, making them opportunists and strangers rather than friends and neighbors. Most prominently mentioned were the East and the rural districts of Oregon and Washington. Evidence of solicitation showed up as far away as the small town of Oroville, Washington, which was situated only four miles from the Canadian border. Formerly a gold boon town, Oroville settled into an economy based on agriculture and tourism. In its search for replacement workers, Crown attempted to reach such cities such as this well beyond the metropolitan spaces of Portland and Seattle. Pulling labor from rural districts became hotly contested among regional employers as the strike continued and the harvest season approached. 
The NWLB recognized this fact. Rather than delay and risk greater struggle among pools of workers and soldiers and migrants moving through the area, NWLB pressed for expediency in resolution of this strike. In an unprecedented act for the region, the NWLB began to intervene, adding yet another layer of story about Camas as a face-to-face community fully able to care for its own, on its own terms.

The Mediation: Nothing to Arbitrate

In November of 1917, Secretary of Labor William B. Wilson, head of the newly assembled Federal Mediation Board (FMB), arrived in Portland to take testimony from the laborers and company. Secretary Wilson believed that "labor difficulties in time of war have their influences beyond an immediate industry affected." ${ }^{56}$ For that reason, Secretary Wilson hoped to expedite an agreement and settlement between the two parties. As in other communities, Camas workers and their union leaders came to the table ready to negotiate, since — like the women bag workers of 1913 — such a scenario redounded to their legitimacy as an organization that could speak for "Labor." Workers' enthusiasm stood out starkly in contrast to the complete stonewalling of mediation by the company. Crown knew that mediation meant concessions they were unwilling to grant. The situation portended a highly dramatic and theatrical public event, a far cry from the evangelizing that occurred in the Camas tennis courts and the arrogant company lecture plopped on "unreasonable" workers' heads at the Opera House in 1916.

Now, unions held pride of place. The strikers were first to testify in the public hearing. The strikers gave "the unreserved offer to be bound by whatever settlement the

\footnotetext{
${ }^{56}$ Wilson's Mediation Commission, 8.
} 
Commission should make and to be so bound for the period of the war." ${ }^{57}$ The labor press and mainstream media published the Camas workers' statement far and wide. It was, simply, news. By contrast, Lewthwaite's characterized the attitude of the Crown as having "nothing to arbitrate." ${ }^{58}$ As a result, the commission felt compelled to address the strike situation with the top managers of the company in San Francisco. Wilson reported:

After a detailed statement of the facts by the Commission, setting forth the present unsatisfactory labor conditions, considered from the point of view of the company as well as the Government, the company courteously but firmly rejected the tender of services made by the President's Mediation Commission. ${ }^{59}$

Taken aback and frustrated with the company's stance, Wilson condemned Crown Willamette and its actions during this time of war in their refusal to negotiate and their actions at the Standifer Shipyard. He meticulously detailed the transgressions, as he saw them, which the company committed against the laborers and the country. First, he railed against the "nothing to arbitrate" attitude so clearly expressed. Wilson felt that this was "an attitude at variance with the modern spirit of industry," and was damaging to both industry and labor; a condition impressible and was, in fact, exacerbated during a time of war. Tellingly, the FMB took the position of "modernizer" and Crown was left to appear stubborn or backward, an unflattering portrait. Now instead, of airing views "privately" in the quasi-public squares of Camas, the company was scolded by the FMB. Wilson felt that educating the public regarding Crown's intransigence was important in properly representing the situation as from the perspective of the Federal Government.

${ }^{57}$ Ibid., 8.

${ }^{58}$ Ibid.

${ }^{59}$ Ibid. 
In testimony to Wilson, Lewthwaite justified Crown's stance. He “admitted that the company's wage scale was at least in some instances too low," but held firm on the principle of non-recognition with the union. ${ }^{60}$ Lewthwaite insisted that there was nothing for the company to arbitrate because the demands of the laborers were invalid. Crown refused to cede any of their power to the workers by meeting with them and legitimizing their organization. What had been an intuitive defense of "face to face" village relations a few years earlier was now, in the crucible of wartime, becoming an entrenched position of anti-unionism. Managers were paid to uphold this position regardless of the intervening party they were facing, even if that party was the federal government. Or, at least, figures such as Lewthwaite were being paid to test the government's resolve. Where was the line between the company, capitalism, and the nation? Between village loyalties and patriotism? Wilson recognized serious issues with the Crown's policies. Yet, in his criticism he allowed Crown to save some face in hope they would acknowledge the union and in so doing, acknowledge their own corporate "citizenship" and loyalty.

Wilson's pivot point with the actions of the company turned on an implied "modernization" narrative and a critique that Crown's view of business, patriotism, and labor were outmoded and not in line with the changing times in industry and labor. $\mathrm{He}$ noted:

Protestations of patriotism by the company have been many and doubtless sincere. It is not a question of sincerity. It is a matter of business attitude at a time when the business attitude concerns the country. In its present attitude the company is disregarding modern standards of industrial adjustment and is unresponsive to enlightened conceptions of patriotism by business men. The guiding consideration of the company is an unchallenged control over its

${ }^{60}$ Ibid. 
employees, leading to a refusal to rectify conceded evils or discuss possible existing industrial maladjustments for fear that such concession....may be deemed a yielding to the power of an organization of employees who are urging an adjustment of such evils. ${ }^{61}$

As I have shown, the labor press gave a more eloquent and incisive critique of strikebreaking as anti-patriotic. However, Wilson's more temperate reframing used the gentler, aspirational prod of progress and "enlightenment" to cajole movement by Crown conducive to the national agenda in wartime. Wilson's assessment gave the company opportunity to come to the table for negotiations and not lose face completely; he offered them "enlightenment." Despite Wilson's politeness, the company still refused to take the opportunity to meet.

The government tried to argue that Crown could not rob necessary industries, like agriculture, of labor just to avoid dealing with its own local unionized workforce. Wilson did not deny that the strikers' efforts seemed ineffectual in stemming the production at the mill, but criticized Crown Willamette for how they maintained that production. The company had blanketed the Northwest and East Coast with calls for workers in the mill. Regardless, the government saw an issue with the "importation of workmen from the East and from portions of the West to take the place of strikes. To induce men to leave useful employment to take the place of men now available." ${ }^{\prime 2}$ The Federal Government feared the conflict would create a ripple effect into other industries, especially agricultural industries in the rural districts from which Crown acquired a portion of their replacement work force.

${ }^{61}$ Ibid.

${ }^{62} \mathrm{Ibid}$. 
Wilson also argued that contentiousness and stonewalling added to stress and strain in both society and economy when cooperation better served patriotism. Frustrated, striking workers looking for work could spread dissention when discussing the strike, the poor conditions at the mills, and their embattled, but proud, union affiliation. For that reason, the Wilson feared influence on other trades, especially sympathy or copy cat strikes. This fear was not completely unfounded. The Building Trades Council of Portland placed Crown Willamette on the unfair list and refused to do any construction for the company. The foremost of Crown's projects was the newly planned Crown Willamette Inn in Camas, which the Building Trades Council and Papermakers claimed was being constructed "for the purpose of housing Scabs." 63 The Building Trades Council included workers from a wide array of unions, such as carpenters, painters, plumbers, steamfitters, sheet metal workers, electricians, ironworkers, engineers, and many more. If the situation escalated, major disruption in regional and national industries might spread.

The FMB expressed fear that the impact on the other industries was not only in the potential for labor upheaval, but also instability in the workforce in needed wartime industries. For example, "a number of strikers who went to work for the G.M. Standifer Construction Corporation at Vancouver, Washington were discharged after repeated visits of the paper mill officials to the yard." 64 Standifer produced ships for the war effort. In 1918 in its internal publication, Over the Top, Standifer proclaimed that "every rivet is a nail in the Kaiser's coffin." Wilson and others found this extremely concerning because

${ }^{63}$ The Paper and Pulp Makers' Journal, vol. 7 (Albany, NY: International Brotherhood of Paper and Pulp Makers, 1918), 28.

${ }^{64}$ Wilson's Mediation Commission., 8 
of the instability it brought to industries important for the war effort. In this sense, the federal government expected corporations like Crown "do their part," even if it meant dealing with a union that they statutorily or constitutionally did not "have" to deal with. The question remained: would they?

\section{Patriotism and the Media}

The short-term answer was: no. Even with the condemning report from the President's Mediation Commission, Crown Willamette refused to back down. The unions, looking to shape the opinion of the moral economy of Camas and Oregon City, had labor friendly media sources, public displays of patriotism, and their trade journals countered the efforts of Crown Willamette. Media sources and those aligned with the company instead of relenting ramped up their rhetoric, calling the workers unpatriotic and espousing their convictions rooted deeply in American ideals.

The union took its cause back to the village and powerfully reframed the debate. On Saturday, November 2, 1917, the papermakers in Oregon City held a mass meeting. George Dunmire, chairman of the strike committee, led the event. It was estimated that 1300 citizens of Oregon City attended to hear the speakers. The intent of the meeting was to give the public an idea of the strike situation from the point of view of the workers and place themselves as patriotic Americans fighting for the common worker against a large oligarchical and unpatriotic company. Speakers were J.W. Hudgens and Ed Meyers, one of the strikers. The goal of this meeting was to get the attention of the local business interests in the city and to develop a dialogue regarding what the laborers saw as a "“autocracy” in industry." 65 It was noted that at the meeting "industrial kaiserism was

65 “Paper Mill Workers Hold Mass Meeting," Oregon Labor Press (Portland, OR),November 10, 1917. 
emphatically denounced and the parallel drawn between 'kaiserism' in Germany and 'kaiserism' across the Willamette." ${ }^{\prime 66}$ The final speaker of the evening was a Dr. William T. Milliken, a pastor from the First Baptist Church in Oregon City. It was reported that Milliken "complimented the men on the orderly manner they had thus far conducted the strike and urged them to continue the same tactics. ${ }^{97}$ Furthermore, he emphasized the need for a full 24 hours off for the mill workers on Sundays "as being in line with Christian ethics...[and] these demands would receive the support of all Christian people. ${ }^{968}$ The workers crafting of messages of patriotism and Christian alignment had the potential of giving them more support from the community in their efforts to win the strike. As a result, they may have envisioned gaining not only moral support but also financial support from the community if they were able to properly disseminate their message.

In Camas, the message was much the same. The workers of that city also held a mass meeting, which was presided over by J.N. Endicott, secretary-treasurer of the Pulp and Sulphite Workers there. It was noted that "not more than 20 men are at work" at the Camas mill. However, to demonstrate their benevolence and care for the most important industry in the city, the "union instructed two fire system men, three firemen and three watchmen to stay in and look after the plant." ${ }^{\prime 69}$ The message worked to align the workers as paternalist of the industry but also in complete control over the situation. It was mentioned that Camas's mayor was a union man and his support was juxtaposed against the Mayor of Oregon City. Clark and the president of the Papermakers' Local in Camas,

\footnotetext{
${ }^{66} \mathrm{Ibid}$.

${ }^{67} \mathrm{Ibid}$.

${ }^{68}$ Ibid.

69 "Paper Mill Workers at Camas Hold the Fort," Oregon Labor Press (Portland, OR), November 10, 1917. 
Frank Frampton, eventually ventured to Oregon City to join in the discussion at the mass meetings being held there. However, an omission was made in this comparison and his involvement in the meetings in Oregon City regarding Clark's party affiliation as a Socialist. It's possible that this hurt the Locals' message of patriotism and Americanism the strikers strove to cultivate.

The Oregonian, owned by Henry Pittock, who also had a large investment in the Camas paper mill, began to shape its own narrative of the strikers and company. As midNovember approached the situation at Camas had been portrayed as peaceful. However, on Monday, November 12, that narrative shifted. It was reported that a group of striking mill employees had beaten a non-union laborer for Crown Willamette in the streets of Camas. R.D. Christopher of the Camas strike committee sent a communication to the paper stated: "Beech fought Deputy Marshals who were arresting him for carrying concealed weapons, and insisted that blows were necessary to make the arrest." ${ }^{, 70}$ Soon after this The Oregonian and The Camas Post were both reporting that the strike was coming to an end. This was another of those self-serving, would-be prophesies, designed to confound, distract, and deflate the strikers. The Oregonian reported that one machine had been started up again and that soon others were be running. The truth of this claim is unclear. Furthermore, it was posited that thirty out-of-ninety workers on strike at the Oregon City plant were going to break the lines and resume their work. Word from Lebanon was much the same. At Camas the report was that the mill was "producing...120 tons [per day]."71 In truth, the company brought in workers and retained acceptable levels of production. This gave them a strong impression their efforts

\footnotetext{
70 "Camas Strikers Reply," The Oregonian (Portland, OR), November 14, 1917.

71 "Strike Nearly Ended," The Oregonian (Portland, OR), November 20, 1917.
} 
to break the strike were successful. However, later concerns surfaced from the NWLB regarding the toll their imported labor force was taking on other industries and necessities for the country in the midst of war. ${ }^{72}$ In addition to the workers returning there was support coming from the government in Oregon and Oregon City.

The propagandistic reports of the workers' lost resolve were buttressed by the actions of the Oregon state government. Governor Withycombe took paramount interest in protecting this vital regional industry. As a result, special deputies were appointed to "protect" the mill in Oregon City. As many eleven special agents were commissioned in the city for this purpose. Later, these agents became a contentious point between the city and state government, the strikers, and the mills. Oregon City reported a more violent atmosphere than Camas; overall, however, they were not immune to confrontations between workers and newly appointed law enforcement.

The towns of Camas and Washougal possessed strong constituencies of Grangers coming from populist roots. The county during this time was rife with farming cooperatives. The Grangers of Washougal, Camas's twin city to the east, attempted to create a farming co-op that challenged the Portland-dominated steamboat system of commerce. The local Grange announced a resolution that condemned "all strikes and lockouts that embarrass the government in the present crises, and favor[ed] that all differences be submitted to arbitration." 73 Their resolution clearly raised concerns about lockouts and strikes equally. The Grangers demanded expediency, from both the company and workers, in resolving the dispute for the good of the nation in wartime.

\footnotetext{
${ }^{72}$ Wilson's Mediation Report, 8

73 "Grange Resolution is Against Strikes," The Camas Post (Camas, WA), November 23, 1917.
} 
The Camas Post used specific and targeted messaging to imply displeasure with labor by the Grangers. The Camas Post's headline for the article explicating the Grangers' actions read "Grange Resolution is Against Strikes." An implication that the Grange resolution was against the labor strike was clear, but not exactly true. Furthermore, the actual text of the resolution was placed in the last paragraph, which was proceeded by an entire column of other news from the Grange meeting unrelated to the headline.

Adding to the campaign against the strike, The Camas Post published a series of other articles intended to lessen the resolve strikers reading the paper. Once again utilizing the headline to make a clear statement, just a few columns away "Paper Mills Will Not Employ Union Labor" presided above another article. A news article that contained little more than utter speculation, the paper reported that though Crown Willamette had not submitted any official statements regarding the future employment of union laborers, the paper believed that "there [was] good reason to believe that no member of a union will again be employed by either the Crown Willamette Paper company or the Hawley Pulp and Paper company." 74 Stepping up the news drum beat, Crown in repeated quotes in multiple media sources continued to state that the company would not discriminate against union employees. However, The Camas Post, acting as an informal voice of the company, made statements on what was most likely the behalf of Crown Willamette. Whether this was intentionally planned between The Camas Post and the company, one cannot know based on extant archives. Nevertheless, a potential chilling impact on striking workers seems to have been the intent.

74 “Paper Mills Will Not Employ Union Labor," The Camas Post (Camas, WA), November 23, 1917. 
The transparent manipulation of the news media only strengthened the resolve of the striking workers. Organization and unionization clarified workers' own communication systems and trust; the mass meetings, picket lines, and even Labor Day represented new spaces where workers spoke their own truth, believed in it, and acted in solidarity based on the words they knew to be true. As their own communication networks grew, new radical ideas came to the front. This early stage of the battle, the union focused on creating unity and awareness for and of their efforts. During the second to last week in November, the striking workers of Camas and Oregon City held several mass meetings. In these meetings they brought in a coalition of allies to help support their efforts. In Oregon City, George J. Schnieder, Vice Presidents of the International Brotherhood of Papermakers, and Ed Rosenbery, a Central Labor council of Portland delegate, spoke at these various meetings. The leadership of the IBPM believed if they educated the public and aroused "the minds of the people to the present economic conditions" for the workers, solidifying public opinion in the laborer's favor, they could keep the union together and strong and make Crown's continued refusal to recognize the union increasingly difficult. All of these elements helped to create a base for organization in the Pacific Northwest paper mills. ${ }^{75}$

In the Camas situation, the people of the city seemed particularly disinclined to support replacement workers. Crown Willamette commissioned a local river steamer named Potter for the use as a hotel from the strikebreakers; there was little physical or emotional space for these individuals in the town proper. Eventually, the Potter provided a shop and dinner arrangements for the workers. Another steamer, the Burton,

75 "Mass Meetings Are Held in Oregon City," Oregon Labor Press (Portland, OR), November 24, 1917. 
accompanied the Potter just days later. Soon after the workers were also provided with "a barber ship and commissary," with all of their needs being cared for either in the mill yard or on the boat, effectively limiting their venturing into the city. ${ }^{76}$ This scenario implies several possibilities. The first possibility being that the people of the city were against these workers taking the place of their fellow Camasonians. However, it is very possible the strikers created a hostile environment for the strikebreakers.

Both media sources for and against the strike refuted the violence perpetrated by the compatriots and vilified the other side. The Oregonian and The Camas Post insisted marauding parties of strikers accosted the "workers" of the mill. For example, it was reported "Workers in the paper mill who went to a near-by store for tobacco this morning were set upon by alleged strikers and a battle ensued, in which two of the mill men were badly beaten before help came. Reinforcements came from the mill and the victims were rescued." 77 Two keys in the public discourse proclaimed in The Oregonian was the framing of the strikebreakers as "workers" and the strikers as "criminals." In conflicts the strikebreakers were named the "victims." ${ }^{.78}$ George Beetsch, one of the strikebreakers, after a confrontation with Chief of Police Falter and strikers, deputized by Mayor Clark, was admitted to St. Joseph's Hospital in Vancouver, which gave evidence of the strikebreakers as victims of physical attacks. However, once Beetsch was released from the hospital he was summoned to the Clark County Superior Court on charges of illegally carrying a gun, which Faler and his men had claimed was the reason for the violence that

\footnotetext{
76 "Camas Strike Continues," The Oregonian (Portland, OR), November 27, 1917.

77 "Camas Workers Attacked," The Oregonian (Portland, OR), December, 4, 1917.

78 "Strike Situation in Camas Paper Mill," Oregon Labor Press (Portland, OR), November 24, 1917; "Camas Strike Continues," The Oregonian (Portland, OR), November 27, 1917; State of Washington v. George Beetsch (Clark County Superior Court 1918).
} 
led to Beetsch injuries. Confrontation between strikebreakers and the strikers, such as Beetsch and Faler's men, gave labor and the company fodder for media attacks. The portion of the narratives unfavorable to their interests was overlooked.

In the public campaign against the company, The Labor Press used the character of the strikebreakers to vilify the company in the patriotism framework. For example, it was reported that "Chief of Police Faler arrested Jack Riley and Walter Payne, strikebreakers, who were wanted in California as alleged draft deserters. However, labor also accused the company of "grinding up the strikebreakers in Camas" and Oregon City. ${ }^{79}$ When the $O L P$ addressed the strikebreakers they both denigrated them but acted paternalistically. They engaged in similar rhetoric as the company and framed the actions of the strikebreakers as lawbreakers or dupes. Using the media roughly twice as much as in 1913, Crown and the Papermakers Union laid out clearly their campaigns against the other. Factions of the public and political were aligning with labor or capital. The entrenchment of the laborers' and Crown's refusal to give up ground was clear. The strikers and Crown had reached an impasse. Both sides settled in for a long winter.

In many ways, the strike was fought in the media; it was about the stories each told of the other and what sectors of the broader community endorsed that story. As the winter wore on, the strikers faced backlash in local and regional media outlets, such as The Camas Post and The Oregonian. Unfavorable reporting of their actions and affiliations, forced the strikers to make the public aware of their patriotic efforts. The Camas Local No. 130 in April of 1917 dedicated a service flag. Their intention to make it clear they were not slackers. The dedication of the flag named only the strikers that had enlisted and

79 “Encouraging News From Camas Strike," Oregon Labor Press (Portland, OR), December 29, 1917. 
not all papermakers. In April, the Paper and Pulp Maker's Journal for April highlighted a dedication of the service flag. The workers continued over the next few weeks and months to add stars to their service flag and to make that known to the public in their journal and by the flag's display.

Crown kept the union busy with answering phony charges in the papers and in wasteful exercises in public displays of patriotism. Local media claimed that Otto Hartwig from the Oregon State Federation of Labor, who had came to Camas to help with the effort, was a pro-German agitator. The Papermaker exposed this claim as libel (though they did not sue). More substantively, the Papermakers also tried to derail the recall of Camas pro-labor Mayor O.T. Clark, who fought and later succumbed to a recall campaign built upon a foundation of claims of sedition, pro-Kaiserism, and betrayal of his home country. ${ }^{80}$

On the offensive, the laborers posited claims that the working conditions and production at the mill were worse than the company claimed. Indeed, the safety of the workers deteriorated over the succeeding months. The Oregon Labor Press reported that 136 claims were filed with the Washington State Industrial Insurance Commission from the Camas mill for December, January, and February, which "for the same three months of the preceding year the total of accidents in the same industry were $48 .{ }^{\prime 81}$

During this time a threatening letter was personally sent to Organizer Smith, warning against pursuing strikes as other locations. The Labor Press argued that Smith needed to seriously consider the no-strike order because "the company [was] getting spruce for areoplane [sic] stock for the British government. A strike would greatly harm the war

80 The Paper and Pulp Makers' Journal, 1918, 27-29.

81 "Strike Situation at Camas," Oregon Labor Press (Portland, OR), April 13, 1918. 
effort." ${ }^{82}$ Smith refuted this claim, explaining that "if the company is furnishing spruce from its forests, a strike in the mill would not affect the workers, and as it is suggested that the mill workers" were not considered disloyal and unpatriotic in the eyes of the government. ${ }^{83}$ Smith saw the implication and threat as wholly fallacious and pronounced that "the company will not be able to get away with the camouflage that the strike is unpatriotic." 84

Retribution against the striking workers regarding the company's patriotism seems to have been on management's mind. Managers from the Camas mill ventured into Vancouver on a regular basis to confer with management from the Standifer Construction Corporation. The next day workers who were on strike from the Camas mill that secured employment from Standifer found pink slips waiting for them upon arrival. In reference to this practice the Oregon Labor Press commented that "we are very sorry to learn that the Standifer Construction Corporation considered that the winning of this strike at the paper mill is of so much more importance than the speedy construction of ships to carry supplies to the boys in France and to the armies of our Allies in the war against the Germans. Some people have very strange ideas on the subject of patriotism." ${ }^{85}$ Cutting rhetoric aside, the strikers discharged from Standifer had little impact on the factory's operation. The wartime work drew workers from across the nation to Vancouver, readily replacing terminated Camas workers. Regardless, the strike's impact, thought subtle, in the shipyards of Vancouver, did not escape the attention of the federal government. Officials from both the strike committee and the company were summoned to

82 "Strike Situation at Camas," Oregon Labor Press (Portland, OR), April 20, 1918.

${ }^{83}$ Ibid.

84 Ibid.

85 "Strike Situation at Camas," Oregon Labor Press (Portland, OR), May 25, 1918. 
Washington D.C. in July of 1918 to appear before the NWLB to explain the situation on the West Coast. This second challenge by the federal government finally exerted enough pressure on Crown to get management to the negotiating table.

\section{International Solidarity and Homegrown Strikebreakers}

In April of 1918, the strike spread from Camas, Oregon City, and West Linn, across international boarders. Indications appeared that a British Columbia mill of Crown Willamette in "Ocean Falls mill will walk out Sunday...this will seriously cripple the company, as it will shut off the support of paper which the company has been shipping to California." ${ }^{86}$ Furthermore, reports from the Papermakers Local in Powell River, British Columbia, declared their support for their American brothers in the mailbag section of the International's publication. They announced:

The strike committee informs me that Powell River is donating much in excess of any other Local and there are none of us going hungry or neglecting those depending upon us for support, and I am positive that we pay as much for living expenses here as any of your Brothers do in the east [sic]...The loosen up those of you who have not done so and put on a strike assessment of at least one-half day's pay at your next regular meeting, no matter what some one says or what you may have heard about Oregon City or Camas, Wash., all of us here know they will win if they are given financial aid, but they cannot fight on an empty stomach, and if the strike is lost it will be because they were driven back through starvation, in this case they will not be to blame. ${ }^{87}$

The changing conditions of labor in the state hampered the new Locals' efforts to raise a solid strike fund from outside supporters. The press reported a group of Oregon City women organized a dance that was able to raise $\$ 400$ dollars for the strike fund. The largest donation at this event came from the Boiler Makers' Union of Portland in the sum of $\$ 250$. It was reported that "women of the city [were] showing a keen interest in the

86 "Strike Situation,", April 20, 1918.

${ }^{87}$ The Paper and Pulp Makers' Journal, 1918, Vol. 17:14. 
strike. ${ }^{" 88}$ Looking to bolster and grow the financial support, union leadership from Oregon City and Camas took successive trips across Washington asking for funds. However, enough outside support to create a strong strike fund in Camas and Oregon City never materialized. Nevertheless, the Locals' leadership continued to spread the word about their efforts and need. In June of 1918, Frank Frampton, president of the Camas Paper Maker's Local, represented the mill workers at the state convention of the Washington Federation of Labor. His prime objective was to gain support for the strike and the workers. However, his pleas were left unanswered and little monetary support from outside the Pacific Northwest. Solidarity that was present between the Crown paper mill workers of the Pacific Northwest, but beyond that support was minimal.

The young Locals in Camas and Oregon City were actively undermined by some of their Brothers from the East. Lists of strikebreakers from locations out east were published. The correspondent from Camas wrote:

We have some rats here, and no doubt you boys in the East and Middle West all know them. I will mention some of their names - some of them are going under assumed names, but we know them at that, and they can't fool some of us old-timers and rounders. Black Jack Gallagher was the first one of our boys going back, and no doubt but what a lot of the old-timers know Old Black Jack...At that time there wasn't a stronger union man in the country than Black Jack Gallagher and, honestly, boys, I couldn't believe it when I heard that Black Jack was scabbing it. ${ }^{89}$

Black Jack was not alone. Many others were detailed in letters from the Camas correspondent. The papermakers, now reaching nearly six months off the job, became increasingly frustrated with the lack of help they were receiving from other organizations and the undermining of their efforts by their Brothers in the East.

88 "Strike Situation in Camas Paper Mill," Oregon Labor Press (Portland, OR), November 24, 1917.

${ }^{89}$ The Paper and Pulp Makers' Journal, 1918, 20-21. 
The lack of solidarity encouraged brief flares of radical rhetoric in messages from the Camas and Oregon City locals. They felt that "craft unionism [was] keeping the trades separate" and that it created "a sad case of one union working against the other." They recognized the fact that other local unions such as the Allied Printing Trades, Teamsters, and Longshoremen were "handling paper that is not only non-union made, but that is made by professional scabs." Yet, calls for radical tactics were fleeting and only appeared briefly. The rhetoric coming from all pro-striker sources remained moderate to conservative in their actions and words. This moderation, combined with the lack of support, weakened the new Locals.

In the end, the strike was less a referendum on the power of unions and their infighting than the inability or unwillingness of the federal government to push Crown beyond negotiation to recognition of the union. Such a shift required more than rhetoric; it required power. In August of 1918, after the striking workers and company officials were called before Congress in Washington D.C., true negotiations to end the strike began. Committees from both the Paper Makers and Pulp, Sulphite, and Paper Mill Workers Unions and Crown Willamette officials met face-to-face in San Francisco. It took nearly one more month for the strike to be concluded. However, in September of 1918, almost a year after they had walked out, the Paper Mill Workers returned to work in Camas, Oregon City, and all other locations. The only concession gained from the Oregon City and Camas Locals was the agreement "that if the strikes were called off the objectionable non-union agreement, which the paper and pulp mills had been required to sign, would be withdrawn, and that members of the union would not be discriminated

${ }^{90}$ The Paper and Pulp Makers' Journal, 1918, 15-17. 
against by the mills. ${ }^{" 91}$ The company refused to make any other concessions. The back of the Locals was broken. Reports of their activities ceased, no correspondences from them in the national journal were submitted for "if they [wrote] Mr. Hopps (sic), [owner/editor of The Camas Post, and] the C.W.P. Co. noisemaker may get noisy again." ${ }^{92}$ Only a few men remained affiliated with the union at the mill and organized labor possessed virtually no presence in the mill until the late 1930s.

91 "Strike Called Off," The Oregon Labor Press (Portland, OR), September 19, 1918.

92 The Paper Makers Journal, 1921, 27. 


\section{Chapter III:}

\section{The Beginning of the End: Political Strife in Camas}

In the late spring and summer of 1917, an uneasy air permeated the halls of government and business in Camas, Washington. The newly formed union locals settled into new civic roles, foremost, planning the first Labor Day celebration in the city. The recent victory in establishing a union at the mill in Camas seemed incomplete because of the lack of a formal contract with Crown. Instead, the company informally recognized the new Locals within the context of the local village ethos, on display at public events and celebrations. Hope for recognition and a contract was, at best, marginal. To get Crown to the negotiation table was, at least, conceivable. The Oregonian, with its usual hyperbole in favor of management, gives us a hint as to what workers faced "from above." The Camas Post appeared more evenhanded, but in truth spoke to and for a conservative audience that viewed changes in labor relations and the disruptions of the strikes and walkouts as radical. A few members of the community, employees at the mill and businessmen, identified this injustice. Capitalizing on the desire of the workers to organize, Oliver T. Clark, a mill employee; Kelley Loe, a local real estate agent and founder of the city newspaper; and Joseph S. McAllister, also a local real estate agent, stepped into the political arena. They campaigned to change the dynamic of the city government to allow for breathing space for the new Locals to assert their demands for recognition and growth. Clarke and Loe held positions in the Camas Local of Washington State Socialist Party. They felt socialist ideals suited the needs of the workers and their placement into positions of power in the city government ushered in the ability to affect pro-labor changes at the mill. These political newcomers built from the 
national Socialist electoral upsurge and the national organization's targeted support of Camas as a potential for organizing. Unfortunately, their aspirations for labor did not come to fruition. While a coalition between the new Locals and Socialist leadership in the city grew quick and strong, opposition from the local business leaders, spearheaded by the Camas Commercial Club, and a temporary unification of local Republicans and Progressives, stymied the ability of labor to make lasting progress politically.

Camas was not an island regarding the push back against labor and leftists before World War I. However, the traditional moral economy of the city and its ensuing evolution tell a different story than those in the much larger and anonymous urban spaces of Seattle and Portland. Though 12\% of Washington State voters voted for Eugene Debs, a Socialist Presidential candidate in 1912 - one of the best proportional showings by the socialist candidate in all of the United States - much of that success localized within large urban areas, such as Seattle. ${ }^{1}$ Local politicians, such as Oliver T. Clark, whose leftist commitments were tied with unionism in the city, needed to remain politically moderate and he emphasized his role as a "friend of labor." In doing so, Clark challenged the Camas ethos of harmony of interests rather than advocated for radical change. In this bid for accommodation, Clark's election opened the door for labor to organize and socialists to gain positions of power in town, which threatened the traditional business leadership in the city. The face-to-face moral economy, such as seen in the tennis court debate of April 1916, shifted from an environment in which the "village" handled the matters of dispute out in the open to a much more closed and company-dictated political economy. This

\footnotetext{
${ }^{1}$ Washington State Presidential Elections "Dave Leip's Atlas of U.S. Presidential Elections," accessed April 1, 2015, http://uselectionatlas.org.
} 
outcome required the expulsion of the challengers from the public sphere and the town, in almost a purification ritual of the city of Camas.

\section{The Changing of the Guard}

As suggested in chapter two, Socialists in Washington State focused on Camas and worked to introduce socialist ideals in the town with an eye toward union expansion. For example, in 1915 Emil Herman gave a lecture at Camas. Herman was a prominent member of the Socialist Party and became the Secretary of the Washington State Socialist party in 1916. At the time, Herman focused on freedom of speech and assembly. He railed: "in my experience as a Socialist propagandist and organizer...I have encountered four cities (Tacoma, Raymond, Port Townsend, and Port Angeles) where freedom of speech and peaceable assemblage is restricted or denied entirely."2 The link between free speech and corporate oppression of workers was easy to make: companies hired private police forces to intimate workers and, as noted, Crown managers corralled both opinion leaders in the media and appointed and elected county officials, including law enforcement, to stifle both speech and organization. During Herman's multiple city campaign to address the recent violence against the freedom of speech perpetrated in all the cities in Southwest Washington, Camas was a chosen as one of only two stops. The goal was to create a local electoral imperative for workers to get to the polls and reinforce the shop floor energy for change and organization.

In May of 1916, another key member of the Washington Socialist Party, Carl Ulonska, came to Camas to speak. Ulonska, a rising, younger Socialist partisan, was a

\footnotetext{
${ }^{2}$ Emil Herman, "Right of Free Speech Denied the Workers," The Northwest Worker (Everett, WA), August 12, 1915, No. 240 edition; "Lectures Held Next Week," The Northwest Worker (Everett, WA), August 19, 1915, No. 241 edition.
} 
figure of great energy and inspiration. His presence and words energized the leadership of the newly established Socialist Party Local in Camas by injecting their ideals into the local moral economy by means of his well-attended presentation and prestige within the state arm of the party. Camas was rarely even a whistle stop in tours of the state by the Democrats or Republicans; Socialist Party attention alone excited the community. The financial secretary of the Camas Local, Oliver T. Clark wrote enthusiastically about Comrade Ulonska's visit. Clark exclaimed:

The Carl Ulonska lecture, delivered at the opera house here May 21st, under the auspices of [Socialist] local Camas, was a splendid success in every way. Comrade Ulonska was well received by the largest audience that ever greeted any lecture or platform speaker in Camas. He at once won his audience by his pleasing manner and appeal to their intelligence. Then by the force of his invincible argument, logic and eloquence, for an hour and a half he held his audience spellbound, and also won a warm spot in the hearts of the comrades of Camas. No admission was charged, a collection being taken after the lecture, which amounted to $\$ 12.50$. $^{3}$

Drawing from the energies of the state leadership, Clark and others of the Socialist Local in Camas campaigned for high-level government positions in the town. The Local was on the city level and was a small piece of the larger state party. Four figures from the city emerged in key positions of leadership, all declared socialists. Clark sought the position of mayor and was joined in the electoral race by J.S. McAllister, whose vision was set on the city Council. Several other socialists reached the general election ballot for the council; however, Clark and McAllister were the only two to succeed. Though operating with fewer allies than hoped, Clark and McAllister established themselves quickly as political allies to the workers of the mill.

3 "Ulonska Holds His Audience Spellbound," The Northwest Worker (Everett, WA), June 1, 1916. 
In fact, what the Camas Socialist Local (CSL) really offered was a narrow pathway for new sorts of secondary entrepreneurs, essentially ambitious small proprietors and managers, to find a way into status and authority alongside of business, rather than in confrontation with Crown. A case in point is the example of J.S. McAllister, a local real estate agent, who brought with him to public office a family association with the pioneer heritage of Clark County. McAllister, born December 8, 1849 in Indiana, came west by covered wagon as a young child McAllister was firmly established as a member of the local moral economy in Clark County due to his longevity in the community.

McAllister served on the police force in Vancouver from 1875 to 1880. In the 1880s, he moved to Fern Prairie, an area just north of the city limits of Camas, where he spent 30 years. ${ }^{4}$ With this reputation for trust and leadership behind him, McAllister's prestige leant credibility to the budding CSL, and he became the first Camas official to be elected on the socialist ticket: Justice of the Peace in 1909. With extensive town and county contacts, McAllister was a friendly and trusted face in times of conflict. He had poured oil on the water back during the women bag worker strike in 1913 and voters rewarded him with a seat on the city council in 1917.

Similarly, Benjamin M. Faler, the new Chief of Police appointed by Clark, had worked for years as a laborer at the paper mill and had recently finished up a term on the city council. He was born in Ohio in 1853, arriving in Camas by 1910 at the latest. He lived out his life in the city with his wife Margaret, who passed away in the late 1920s, and daughters, Amy and Allie. Both McAllister and Faler, with deep roots in the

4 “Joseph S. McAllister," The Oregonian (Portland, OR), December 30, 1938. 
community, helped to make the "friend of labor" ethos of Oliver T. Clark mean something in the day-to-day life of Camas workers.

Kelley Loe was the most mobile and new figure of the new Socialist in Camas. A native son of Missouri, Loe had long been involved in the newspaper business and arrived in Camas around 1909. Before Clark's victory, Loe served as a Justice of the Peace and upon Clark's election retained that position. Unlike his previous terms, where he was known as a Republican, Loe fully embraced Socialism. His evolving partisanship found expression through the many newspapers he owned throughout Clark County, like the Ridgefield Reflector, The Camas Post, and Washougal Record. Hardworking and ambitious, Loe went on to become a major public relations figure for the A.F.L in Oregon. He later paired up with Richard L. Neuberger, Oregon politician, journalist, and author, to co-write An Army of the Aged: A History and Analysis of the Townsend Old Age Pension Plan in $1936 .^{5}$

In this period, labor's foes painted socialists as un-American aliens and foreigners. Camas was no exception, except the targets were native-born. Faler and McAllister were long-time residents of the town and employees of the paper mill. McAllister was chosen as the representative of the workers during the tennis court forum during the Strike of April 1917. Conversely, Clark and Loe were relatively new to the community and had less social standing in the "labor village." Yet, Clark and Loe were not complete outsiders.

Clark quickly worked to establish roots and a voice regarding both his place within the "labor village" and his support of labor. In 1910, records show Clark to be a

${ }^{5}$ Richard L. Neuberger and Kelley Loe, An Arm of the Aged: A History and Analysis of the Townsend Old Age Pension Plan, First Edition (The Caxton Printers, Ltd, Caldwell, ID, 1936). 
member of the Knights of Pythias in Camas and represented the group at meetings around the county. He performed this role for several years. After his election in 1917, Clark was elected to membership in the Camas Commercial Club, the organization that eventually called for his removal. ${ }^{6}$ By working to bridge rather than reconfigure norms of interaction and social organization between shop floor and city hall, Clark subtly made real his "friend of labor" style, leaving direct confrontation to the side. This approach had its merits in that it did not challenge the small town ethos of caring for one's own through established channels. But like the shop-floor worker-led upsurge that forced union leadership to catch up and then failed to close the deal in the strike situation of 1917, Clark's tentative stand-alone party, the Socialists, was easily abandoned by voters when the going got tough in town. For their part, Camas business leaders exercised few scruples when they enlisted media and figures outside of Camas to launch attacks against labor and the Clark administration. For example, The Oregonian and the Camas Commercial Club collaborated to bring in an anti-pacifist and anti-socialist speaker, “Three Finger" Jack Godwin, to town. Godwin was a potent figure. Essentially a propagandist for hire, Godwin toured logging camps damning the action of the I.W.W. and Pacifists in these years. His presence in the city was intended to equate Clark and the striking workers to what many perceived to be a suspicious outsider, the I.W.W. ${ }^{7}$

While the archival record is not explicit on this point, it seems that Clark's rise to power in Camas was supported with money and legitimizing rhetoric from outside of town, though it seems not the I.W.W. Of course the Debsians had an interest in

${ }^{6}$ Camas Commercial Club Records (Camas, WA) August 28, 1917.

${ }^{7}$ Camas Commercial Club Records (Camas, WA) February 5, 1918; "Godwin at Camas," The Oregonian (Portland, OR), March 3, 1918; "Had Skirmish with I.W.W.," The Camas Post (Camas, WA), November 23, 1917. 
encouraging local socialists of almost any flavor in their efforts to mount a real third party challenge across the nation. During Clark's run for the mayor, a prominent figure arrived in Camas before the election, the secretary of the Washington State Socialist Party. In March of 1917 H.H. Stallard, four-time Socialist Candidate for the United State Senate, came to speak in Camas. ${ }^{8}$ The Northwest Worker bragged:

This is our time. I had seven hundred at Camas last Monday night. At Woodland they gave me the biggest meeting the place has had for a long time. This is the best time I ever saw for our work, and I am going till they "throw me in."

After Stallard's visit, an even more prominent figure from the national party came to town. In late October of 1916, George R. Kirkpatrick, the Socialist candidate for Vice President, visited Camas in support of Clark's run for Mayor. The rather worried The Camas Post noted: "the distinction of assembling the largest audience ever gathered in Camas to hear a political discussion." ${ }^{10}$ After an introduction by Clark, Kirkpatrick spoke that evening against the traditional parties and the treatment of workers. With his support within the city and outside from regional and national figures, Clark walked a line between membership in local moral economy and being a comrade in the struggle against Capital. The problem with this sort of organizing is that in terms of public theater and media presence, elites simply became suspicious and started planning their counterattack. And of course, once national and regional allies left, the fledgling organization in Camas had little to show in its arsenal with which to confront corporate power.

Of the four Socialists in power in Camas, Loe was by far the most vocal and seemingly the most powerful. His power lay in his ability to legitimate calls for help or

8 "Lecture Dates for New Week," Oregonian, April 5, 1917.

${ }^{9}$ Wash. Notes The Northwest Workers (Everett, WA), April 26, 1917.

10 "The Socialist Draw Record Attendance," The Camas Post (Camas, WA), October 27, 1916. 
call out violations of rights through administration of justice. Furthermore, Loe's

credibility and authority was of concern to the business leaders of the city. Loe, as Justice of the Peace, could grant permits for dynamite, and as Crown fought back against the workers, accusations regarding abuse of this power were pronounced in the media. ${ }^{11}$ In addition, Loe's reputation as an eloquent public speaker in a town that still prided itself on talking together proved invaluable. His way with words and understanding of media aided Loe throughout his career in public life.

Born in Modena, Missouri in 1881, Loe had a passion for journalism at a young age. At the age of fifteen Loe found a job in a printing office for a publication called the Advance, which was published in Mount Moriah, roughly nine miles from his hometown. By the age of twenty he was publishing and editing his own newspaper in the town of Modena. In 1901 Loe sold the interest in his paper and headed west, arriving in 1902 in Klickitat County, Washington. Soon after his arrival, Loe established the Centerville Journal. It was in Centerville that Loe first entered the civic realm. While there he became a member of the Modern Woodmen of American, the Woodmen of the World, and the Grange. Given his orientation toward social change, Loe affiliated with the Republican Party when he began in politics. Though his involvement in politics during this period of his life ends there. His paper thrived and during Loe's stay in Klickitat County the subscriptions to his paper grew steadily. A local history of the county praised the Journal as "a meritorious publication, neatly printed, and always filled with

\footnotetext{
${ }^{11}$ Camas Commercial Club Records (Camas, WA), February 5, 1918; "Camas Sets Heel on Seditions Head," The Oregonian (Portland, OR), March 11, 1918.
} 
interesting matter, and it is constantly." ${ }^{12}$ By 1908 , Loe had left Klickitat County for Clark, where he quickly established papers in the cities of Washougal, Ridgefield, and Camas. All have remained the keystone publications in those respective cities since that time. Loe, with his wife, wrote for and published various publications. They eventually sold the papers in order to free him up for new endeavors.

Loe's media aspirations were tied to his civic and political ones. In the same year he founded several Clark County newspapers, he applied for a franchise for an electric light system in Camas. When he failed in this endeavor, he turned his attention to politics. By 1912 Loe was well established in local real estate and that same year was elected a Justice of the Peace in Camas, a position he held until his ouster in 1918. In the meantime, Loe established connections in the local business community and was elected a member of the Camas Commercial Club where he was quite active and served on committees. Though the timeline is unclear, by 1916 Loe had declared himself a member of the Socialist Party of Washington State and was the secretary for the Camas Local. Something of an "organic intellectual," Loe became a political architect, writer, and strong advocate of labor.

Loe was not centered within the local moral economy of Camas, but he could read a landscape quickly and seize an opportunity when he saw it. His sympathies were authentic as well as instrumental. Essentially, he argued that unions were new, and the Socialist Party was new. If they stuck together against the established Republicans and Democrats, they should do very well indeed. As he put it in 1917:

${ }^{12}$ An Illustrated History of Klickitat, Yakima and Kittitas Counties: With an Outline of the Early History of the State of Washington (Unigraphic, 1904), 345;446. 
Local Camas...decided to try to effect a county organization and we want to get in touch with all the locals in the county. We hope when the organization is perfected to get an organizer in the field and to secure enough members in the various communities to have at least twenty live locals. With a year and a half to work, we believe that we can put up an interesting fight in the next county campaign with a good chance of electing at least part of our ticket."13

Loe was a chief correspondent from Camas to The Northwest Worker, which received reports from Camas that credited the organized workers at Crown. Shortly after the end of the strike of April 1917, The Northwest Worker reported:

With the assistance of the Socialist Party Local at Camas, the unorganized paper mill workers at that place won their strike for an increase in wages and the right to organize. We had a Socialist mayor and chief of police at Camas, which accounts for the fact that no working class heads were broken during the strike." $" 14$

The assessment of the new Socialist administration's role in the success of the workers to organize was apt. By not intervening with law enforcement the socialists allowed Labor and Capital to work out their differences equitably. Nonetheless, the simple math computed by Loe at the ballot box and shop floor, a strategy of pure numbers, was yet untested in terms of taking on Camas economic elites. Without the legitimating force of statute for unionization itself, the Socialist Party acknowledged it had a hard fight ahead for sustainable loyalty among the rank and file as well as for general acceptance as a vehicle for power against more established authorities.

Quickly reframing the promising but untested nature of the Socialist third party challenge, the voices of tradition in Camas overreacted, hoping to overheat the rhetoric and destabilize any momentum that might be in the offing. Upon the election and appointment of Clark, Loe, McAllister, and Faler, those on the council who found

\footnotetext{
13 "Wash. Notes" The Northwest Workers (Everett, WA), April 19, 1917.

14 "Wash. Notes" The Northwest Workers (Everett, WA), May 3, 1917.
} 
themselves now jostled with new alliances and allegiances, began to cry out in fake fear. The first meeting Clark presided over, a member of the council E.E. Copley, local clerk at the Ferrell Clothing Store, stepped down. Clark had to recommend a replacement. He and McAllister attempted to appoint Jack Mitchell, another Socialist politician who had lost in his bid for the council in the previous election. The other members of the council, whose majority hailed from the Republican Party, voted overwhelmingly against Mitchell. A.C. Allen, president of the Commercial Club of Camas, was appointed to the vacant position. This sharp rebuke to duly elected officials attests the middle-class and bourgeois members of the city only slight willingness to accommodate any "friends of labor" in the form of radical politics. Figures such as Charles Farrell, regional merchant who owned retail stores in Camas and Oregon City, and Rome J. Blair, owner of the Camas Meats Company, showed their willingness to accommodate Crown at the expense of political newcomers in conducting the city's work. Such machinations proved a harbinger of the embattled Clark administration. ${ }^{15}$ However, after this first contentious encounter the business of administering the town's affairs carried on peacefully. Members of the community even presented the mayor with a gavel. The "labor village" tolerated the change in the political structure for the time and the fragile new dynamic between the old and new guards, but local anxieties remained. As Clark and Loe melded into the background of business and politics in Camas, they continued to participate in civic events and organizations. For the next several months, one would have not known city leaders of Camas were socialist. ${ }^{16}$ Such was the price of their Socialist partisanship.

\footnotetext{
15 "Polk Directory - Vancouver and Vicinity" (Seattle, WA: R.L. Polk and Company, 1919 1918).

${ }^{16}$ Camas City Council Minutes, February 13, 1917.
} 
Given the rapprochement, implicitly, adaptation rather than confrontation with the political and business interests in Camas, Clark experienced a short period of peace and cooperation. Mayor Clark attended to his duties. The moral economy had adjusted, for the moment, to the new conditions, which seemingly only required token acknowledgement of labor rather than full empowerment and willingness to confront inequality. An early public ritual sketched the outlines of the new (old) order. The new mayor gave a rousing and patriotic speech at a flag raising making "an excellent address, quoting Riley's 'Old Glory' and dwelling upon the meaning of the National flag," while "the Camas Commercial Club band played patriotic airs and the hugs [sic] crowd of nearly 1,000 joined in National songs." ${ }^{17}$ Clark and the business leaders of the city seemed to translate accommodationist politics and the mythos the "labor village" into National Patriotism. As the possibility of the United States entering into the war in Europe surfaced, both the socialist and business leadership voiced objections to the United States' involvement. The state and national Socialist Parties denounced the possibility of entering the war and advocated pacifism. The Commercial Club, true to its usual concerns of boosterism and money-making, issued a statement in favor of avoiding the U.S.'s entry into the war. Ironically then, a kind of critical, locally rooted nationalism (perhaps a brand of isolationism) briefly created some common ground between business and labor. The nation should serve its own local people and attend to its own conflicts rather than those of foreigners "over there." The Commercial Club wrote:

Whereas, the US has been forced to break off diplomatic relations with one of the European countries now at war, and whereas there is grave danger that our country may be drawn into war, NOW, Therefore, we the Camas Commercial Club, join in asking our representatives in Congress to use all

17 “Flag Raised at Camas," Oregonian (Portland, OR) April 8, 1917. 
honorable means to avoid war, but if war is unavoidable we demand of our representatives that they back up our government in every possible way. ${ }^{18}$

The note sounded around "honor" is crucial here. Implied is a definition of duty, indeed "manly duty," calling up concepts like protection of home and family. Where a man's honor began and ended was precisely at issue here. Did the market and business dealings best support patriotism and the nation, as it advanced the material interests of the citizens (albeit inequitably)? What about the draft and the putting of the nation's sons into battle and harm's way? How should the dictates of "honor" find expression in the political realm—whether the shop floor, the ballot box, or the battlefield? These unasked questions simmered beneath nervous pronouncements about war preparedness. A few months later, the United States entered the war. At that point, these unresolved questions about how to meet one's obligations to institutions, to community, to family, and to comrades boiled over in small town Camas. Though the U.S. did not fight long in WWI, the small town ethos of talking together and taking care of one another did not withstand the stresses and strains that participation produced.

\section{The Battle for the School Board}

The test of "honor" and the self-concept of Camas as a face-to-face community that policed itself boiled over not in the area of the mills but the schools. Given the propagandistic thrust of socialism and the Party's effects, combined with its connotation as "foreign" at this point in its development, it is perhaps not surprising that the forces of reaction and fear turned to the schools to beat such influences in the educational game. As institutions that mingled public and private interests, schools represented the community's sense of itself and its future aspirations. Schools in U.S. culture are also

${ }^{18}$ Camas Commercial Club Minutes, February 6, 1917. 
sites where the ethos of American innocence, drawing from stereotypes about "childhood innocence," gains much of their emotional purchase and find significant social expression. Like the Labor Day celebration, the rituals of the school year with all of its pageantry and family pride and hopes for economic mobility in the next generation, provide a key venue for community self-concept and self-identity. In 1917, a political battle over the Camas School Board stretched the mythos of the "labor village" to its limit. The face-to-face quality of social relations was broken and Camasonians feared the indoctrination of their children with Socialist ideas. Like the fight over who would protect and befriend "Woman" in the 1913 bag factory work stoppage, Socialists and Republicans, many prominent members of the Commercial Club - and their temporary allies—squared off around the idea of "protection," this time of Camas's children. In March of 1917, the CSL shifted their focus from the city council to the school board. Outsiders, beyond the "labor village" strongly supported their campaign. A leading Seattle socialist and anti-war advocate, Kate Sadler, spoke on the evening of March 2, 1917 in support of their efforts. However, Camasonians feared this change and waged a massive offensive - mostly aided by a temporary coalition from across the moderate to far-right political spectrum —against the Socialists. Like Clark's election, it was a close call at the ballot box. Ironically, it was the Republicans who turned the "free speech" argument against the Socialists, deeming their ideological agenda to be anathema a properly "free" American educational environment suitable for children. This idea and argument soon manifested itself in the removal of teachers from the school for seditious speech. This move found the Socialists off guard and outfoxed; Clark and Loe were 
unable to respond quickly enough to quash this rather sharp-eyed if self-serving turn of the public discussion. Kelly Loe penned a letter to The Northwest Worker explaining:

Nearly seven hundred votes were polled at the school election - the largest number ever cast in this city at any election. While we lost by 72 votes, we feel that we have won a great victory. The issue was squarely drawn, and we were able [sic] to get over three hundred votes. The opposition which was backed by the leading republicans, democrats, bull moosers, prohibitionists, businessmen, Spanish war veterans and some of the church organizations, to say nothing of all the cliques and factions in the town that have ever been organized for any purpose, used seven automobiles to get out their vote, in an effort to beat the Socialists so badly that they would be discredited to such a degree that they would not put another ticket in the field. As usual, we are now beginning the campaign for the next election, and our first activity will be toward securing more members for the local. ${ }^{19}$

The battle over the school board replayed in embattled efforts between the Socialist administration and business and civic leaders at every turn. The mythos of the "labor village" in the informality and inclusiveness of the spontaneous "tennis court discourse" morphed. The face-to-face debates transformed into political skirmishes in which both sides were more sharply drawn. The public sentiment for informal if competitive public discourse between the voice of the old guard and the leftists evaporated in the climate of fear and accusations. The social mortar of the mythos of the "labor village" weakened and long time bonds between members of the community mattered less and less.

With roughly a year of quiet co-existence in city hall, the Camas Commercial Club went on the attack in January of 1918. Apparently provoked by the lack of action by the mayor against strikers, the recent appointment union leaders' wives as special deputies, and the attempt to take over school board by Socialists, they now sought to

${ }^{19}$ Wash. Notes The Northwest Worker (Everett, WA), March 15, 1917. 
reorder city hall itself. ${ }^{20}$ Suspicion and threats were rampant, fanned by an irresponsible press. For examples, in January of 1918, Councilman Mathis of the Republican Party resigned. Unwilling to let this opportunity to recoup power pass by, "a petition was handed in... which carried a large number of resident's signatures requesting Claus Buhman be appointed to fill the vacancy of Councilman from the Third Ward," a neighborhood of paper makers and general laborers from the mill. ${ }^{21}$ Buhman, like other members of Clark's administration, was a member of the Socialist Party. However, unlike the others, he was German American, born in Germany in $1890 .{ }^{22}$ Despite the Ward support of Buhman, Republicans leaders on the council used their voices to discredit his nomination and voted uniformly against him. In their critique, they deployed the rhetoric of patriotism and xenophobic fear to cast suspicion on Clark's nomination of Buhman. ${ }^{23}$

Clark, for his part, was distracted and even undermined by other doings in the neighborhood. Because the AFL had failed to really embrace worker's restiveness and channel it into solid organization, there was increasing fear of social disorder, fanned by Crown. In addition, plumping up patronage through police appointments did not simply equate to more fair administration of justice: it actually just put more guns in the hands of nervous and relatively untrained officers. For example, the county had increased its number through mass appointments of new deputies by Clark County Sheriff E.S.

\footnotetext{
${ }^{20}$ Camas Commercial Club Records, Special Meeting of the Camas Commercial Club, January 1918; Camas Commercial Club Records, February 3, 1918.

${ }^{21}$ Camas City Council Minutes, January 22, 1918; Year: 1920; Census Place: Camas, Clark, Washington; Roll: T625_1921; Page: 15A; Enumeration District: 9; Image: 1060 .

22 "Camas Socialists Busy," Oregonian (Portland, OR), February 2, 1918; Year: 1910; Census Place: Columbia, Clark, Washington; Roll: T624_1655; Page: 11A; Enumeration District: 0058; FHL microfilm: 1375668

${ }^{23}$ Camas City Council Minutes, January 22, 1918.
} 
Biesecker, state president of the Sheriffs' Association. Many of these men were rural residents, operating far outside the culture and ideology of nascent socialist organizing on the shop floor in Camas or in the nation's labor movement. As The Oregonian was all too eager to point out, their sworn duty was "to suppress mob violence, prevent the destruction of private or public property, which in time of war might be of great value to the state and Nation, and prevent and arrest and prosecute those who may defame the United States Flag. ${ }^{24}$ Fear of seditious and foreign traitors resulted in a new motion in council nominating local, and American born, W.W. Philbrick for the replacement seat. Only Councilmember McAllister voted from Buhman, and he also stood alone against Philbrick. ${ }^{25}$ The business leaders successfully awarded members of traditional moral economy and maintained the balance of the council in their favor. They wanted power to be in the hands of their own. Lacking defenders in the media or access to their Party's bank account, Clark, Loe, McAllister, and Faler were effectively boxed out of influence as duly elected officials of the Camas City Council.

With the police forces in quiescent acceptance of their new mission to defend the flag and take orders from their superior, the conservative elements in and around Camas found themselves strengthened at the grass roots level. New policing forces, as new as the union organization, had no loyalty or ties, partisan or neighborly or familial, to the Paper workers. Sensing an opportunity not to be missed, the Commercial Club shifted the local discourse in a patriotic and militant direction, music to the ears of county law enforcement. With the United State a declared actor in the war in Europe, J.D. Currie, local lawyer and military veteran, in a June 5 meeting of the Camas Commercial Club

24 "Sheriff Organizes Staff," Oregonian (Portland, OR), April 14, 1917.

${ }^{25}$ Camas City Council Minutes, January 22, 1918. 
brought up the question of establishing a Home Guard in Camas, which would effectively militarize the town square (or tennis courts!). A week later, Currie reported back on the successful organization of the Home Guard. ${ }^{26}$ The club also voted to purchase patriotic buttons for the members of the Home Guard at the expense of the club. ${ }^{27}$ In a matter of weeks, Clark Loe, McAllister, and Faler became causalities of patriotic and nativist backlash. Within a year, neither Clark or Loe remained in Camas, a place they had called home for nearly a decade.

In the spring of 1918, Clark, Loe, McAllister, and Faler fought for their political lives in town. The business elite proceeded to physically remove the Socialist presence from the city limits. They accomplished this by dominating the media and effectively crowding out the town square of Camas and filling it instead with a rural militia whipped up with patriotism and utterly outside the local industrial camaraderie and enthusiasm of the shop floor. On the first day of 1918, the president of the Commercial Club called the membership to order. The first order of business was to recall Mayor Oliver T. Clark. Discussion about the advisability of this move took place. In the end, nearly all members voted to recall Clark. A motion passed "to set aside $\$ 50.00$ for expenses for the [recall effort] and if more was needed a special levy would be assessed." ${ }^{28}$ The process of erasure had begun, allowing the Commercial Club to protect its central role in shaping local moral economy. They did not trouble themselves much with ideologies, left or right, pro- or anti-war. Instead, they eliminated the allies of labor as outsiders (ethnically "German" if not quite "foreign"), making Crown the "only" and thus legitimate arbiter of

\footnotetext{
${ }^{26}$ Camas Commercial Club, June 5, 1917.

${ }^{27}$ Camas Commercial Club, June 19, 1917.

${ }^{28}$ Camas Commercial Club, January 1, 1918.
} 
"home." Crown did not need seek to win votes or ideas or even emotions "on the merits." Instead, the Commercial Club removed the single local protective element for organized labor and eradicated leftist influences to the benefit of the company in their endeavor to break the union and its expression in politics once and for all.

The easiest tactic with the broadest and seemingly "non-ideological" appeal was patriotism. With a list of charges ranging from negligence to seditious speech, the majority of the members of the Camas Commercial Club signed a petition for the recall of Clark as Mayor. It was estimated in total that 140 Camas residents signed the petition. Both sides launched impassioned campaigns. The business leaders went back in recent memory and blamed Clark's support of the striking workers for the recall, painting organized labor as a source of disorder and discord. They accused him of protecting union workers who had committed violent acts against non-union replacement workers. ${ }^{29}$ Ironically, when Crown was asked by the FMB to defer patriotically to the war effort by recognizing the Papermakers, they refused to yield to the request of the FMB. Such a turn of events suggests the limits of ideology and the power of capital and money to speak past ideas that did not have guns or other brawn behind them. Armed with all the force of the Commercial Club and the Portland media, an effective campaign was launched to discredit and demonize Clark and his allies. Rhetoric of nativism, sedition, and espionage filled media reports. It was also posited that in the nomination of Buhman for the city council, which failed, the Clark and the Socialist Local was trying to commit voter fraud. The Oregonian and The Camas Post contended the petition presented for Buhman's nomination possessed only forty-three signatures registered voters out of

29 "Mayor's Removal Sought," Oregonian (Portland, OR) January 15, 1918; "Petition for recall of Mayor O.T. Clark, of Camas is Filed," Tacoma Times (Tacoma, WA), January 15, 1918. 
seventy-one total signatories. The accusation levied against the unregistered voters was that some of them were alien enemies of the nation. ${ }^{30}$ In the same breath as the allegation of voter fraud, The Oregonian also worked to connect the striking workers and the Socialist administration to the I.W.W, which seemed to have a nominal presence in the town but was an excellent perceived evil to affiliate with an enemy. ${ }^{31}$

The Oregonian was not the only media source that weighed in on events in Camas. The homegrown paper, The Camas Post, was also on the offensive against Clark and the other Socialists. Lending a voice from the local moral economy, George Hopp, the publisher and editor of the paper, was the campaign manager for the recall. In February of that year, the Commercial Club, with its knowledge of The Camas Post's alignment with the recall effort, passed a motion to have a copy of the city paper mailed to all registered voters in the city at the expense of the club. ${ }^{32}$ In this tidal wave of reaction, even the trusted Kelly Loe came under scrutiny. One of the primary concerns of the Commercial Club and City Council was that because of Loe's affiliation with local labor and the Socialist Party that he might use his position as Justice of the Peace to dismiss criminal charges against strikers and issue permits for explosives to those interested in revolution. They instructed the club secretary to "ascertain who [had] the power to issue high explosive permits in the community. If in the hands of Kelly Loe [they directed that] a protest be filed and a recommendation be sent to the [County] Clerk that Justice of the Peace F.G. Hadley be appointed for the purpose. ${ }^{\prime 33}$ Fear that the Socialist leaders of the

\footnotetext{
30 “Camas Socialist Busy," Oregonian (Portland, OR), February 1, 1918.

${ }^{31}$ Ibid.

${ }^{32}$ Camas Commercial Club, February 5, 1918.

${ }^{33}$ Ibid.
} 
city aligned with foreign, here "German," elements allowed members of the Commercial Club to accuse Loe.

The Oregonians ' propaganda also aired the accusation that Socialists had infiltrated, and thereby poisoned, the local schools. ${ }^{34}$ Concurrent with the recall of Clark, local high school teacher Emma Roth was removed from her position at Camas High School and a matter of time after that left the city. She was charged with seditious speech by the media of Camas. Whether those charges reached beyond the court of public opinion, the remaining records do no indicate. ${ }^{35}$ This time around the Club was much more vocal about its need to find what they viewed as a suitable candidate for the school board and cement opposition against any and all socialist candidates for the positions on the board or of school director. ${ }^{36}$ After all, Loe and Clark were dues-paying members, but now such transactional affiliations became newly suspect. In their meeting on February 13,1918 they conducted a "general discussion regarding the attitude of some of the members of the Club [that] resulted in a decision to drop their names from the roll." ${ }^{37}$ On a unanimous vote O.T. Clark and Kelley Loe were removed from the club. It seems Loe was absent from this meeting and the minutes note that Loe was to be notified of this action and given the specific reasons for the expelling from the club. ${ }^{38}$

Clark and his allies did not stand idle in the face of the recall effort and propagandized their position in their own manner. The Oregon Labor Press, coming to Clark's aid, portrayed the Camas City Council as in the pocket of the company. They

\footnotetext{
${ }^{34}$ Ibid.

35 "Disloyal Teacher Quits," Oregonian (Portland, OR), February 5, 1918.

${ }^{36}$ Camas Commercial Club, February 5, 1918.

${ }^{37}$ Camas Commercial Club, February 13, 1918.

${ }^{38}$ Ibid.
} 
published the entire list of petition signers with commentary on their affiliation or allegiances to the company. Clark worked to give the continued impression of his political independence from the company in battled at city hall. For example, Clark vehemently objected to a request by the company for the vacation of certain streets within the city. He asked that the vacation not be granted without something of value in return. The council ignored his efforts and passed the motion. ${ }^{39}$ The vacations of certain streets had been common place in the city before and during Clark's administration and his effort at this time could be viewed as political posturing.

Outside of the council chamber, the partisans of the Socialist administration worked to explain and legitimize the actions of the Mayor, defending his record and rebutting charges of negligence and underperformance. Nonetheless, the labor press found themselves under pressure to discredit the libels in similar, patriotic terms rather than in radical ones. They reported that "Chief of Police Faler arrested Jack Riley and Walter Payne, strikebreakers, who were wanted in California as alleged draft deserters. ${ }^{" 40}$ The power of many of the members of the city council, local business leaders, and the local press removed Clark in the recall vote. On the evening of March 9, 1918, the Camas City Council met in special session. The official vote in the recall election was tallied. The result was 338 for recall and 123 against. Shortly after this vote, Loe and McAllister were both removed and Clark and Loe left the city. W.E. Farr, the city clerk, was elected Mayor of Camas. In the midst of Clark's recall, there were other causalities. B.M. Faler was also removed from his position and a new marshal was installed. At this same time the Council voted to raise the pay for the marshal of the city. The remnants of Socialism

\footnotetext{
${ }^{39}$ Camas City Council Minutes, February 26, 1918.

40 "Strike Situation at Camas," Oregonian Labor Press (Portland, OR), January 26, 1918.
} 
were all but purged from the town record and the company and town leadership reunited with a stronger relationship than before. 


\section{Conclusion:}

\section{Memory and Monuments}

For many decades historians have examined labor in the West. Monographs describing the genesis and outcomes of strikes, the rise and fall of company towns, and the circuitous paths of labor organizing are plentiful. That story is generally one of spurts of radicalism followed by more or less fraught accommodation to stronger powers rather than one of lasting shifts in the political economy, at any scale (community, industry, or state). As I noted in at the outset of this project, the Pacific Northwest figures only slightly in this larger story of "the" labor movement in "the" West. Washington's statewide I.W.W. strike, the Seattle General Strike, and the events in Centralia (massacre or riot) have garnered most of historians' attention, but reside on the periphery of the Western narrative. This thesis has attempted to begin to recover and reconnect a small town industrial story within some of these larger trends. In addition, I have been interested in the erasure of evidence and memory of labor's story, in no small part because I had to be.

Clearly, more scholarly work needs to be done to bring Camas into the fold of the region's story. Since Seattle's story was better documented at the time and made headlines, it is not surprising that scholars have been drawn to vivid and transformational events there in the region's history. However, if historians only attend to what is in the archives, they simply repeat the archives. As a public historian, I am well aware of the incompleteness of archives; indeed, as many critics have pointed out, archives are sites of forgetting as much as remembering. Museums tend to fall into the same trap: they tell 
what is saved and preserved, and are challenged to recover stories that have not left artifacts or paperwork behind. Often the documents of an archive are a greater reflection of the perspective of the powerful in the period in which they were collected than a broader, majority context when they were created. People create archives and the bias, emotions, or ignorance of people can influence collections.

My work addressed a key gap in the historical record. I redress a historiography, which frames Southwest Washington as having "nothing to research" beyond the famed fort and military barracks. ${ }^{1}$ Instead, my research reveals not absence but erasure of labor's story, and the different is crucial. My investigations have examined the before, during, and after significant series of events involving the region's working peoples' that have been actively forgotten. This forgetting has until now relegated the importance of the events in Camas from 1913 to 1916 to the status of a historical footnote in academic scholarship, save for a superficial examination of the labor components. The same can be said for politics, labor, and law within the context of Southwest Washington. During World War I, both the Camas paper mill and the Spruce Mill, located in Vancouver, Washington, were key industrial cogs in the larger regional and national system. The fact that little attention has been paid to labor and leftist politicians during this period by scholars presents, instead of a bitter omission, a rich opportunity for historical exploration and discovery.

If reading this work accomplishes anything for the reader, the most important achievement is opening the conversation for other scholars to examine these topics and

\footnotetext{
${ }^{1}$ It must be noted, a section of the website for Center for Columbia River History interprets Southwest Washington at the academic level, and specifically Camas. This site stands alone in its examination of the labor conflict in Camas and expands further into narratives and decades well beyond the scope of my work. To read in detail please visit - http://www.ccrh.org/comm/camas/index.php
} 
ideas within the context of Southwest Washington and tap a neglected archival record of conservative, moderate, and radical politics, labor activity, and laws. I look forward to challenges to my assessment of the events in Southwest Washington described in this work, because my research and writing has merely poked a pinhole in the shroud of time covering a largely unknown landscape of history. Memories may have failed or actively willed forgetting, but the collective of historians can strive to uncover, examine, and understand what we've decided to forget and why.

During the decade of the 1910s, Camas, and many Northwest towns and cities, fought for their soul and identity, but this history has experienced a rather efficient erasure. Labor and leftist politicians were present, if not at times abundant, in Southwest Washington. However, nativist and patriotic rhetoric and government-supported dismantling of the unionism and leftist politics left only the smallest bits and pieces of their history for us to explore. As a result, cities like Camas took their politics and economies in a conservative direction. In the process, they shouted down the idea of a workers' utopia and an alterative to Capitalism, which seemed a possibility only a few years earlier, especially if one listened to ambitious national and international voices about the matter. Socialism, communism, and radical-left ideals garnered significant, if short-lived positions of power in the Northwest and the nation before World War I. However, in the small company town of Camas, the opportunity was fleeting and the door all but permanently closed.

After the strike of 1917 and the recall of 1918, Camas strongly asserted and embraced its identity as a company town. This was the town I grew up in. When I first saw a monument to Camas's labor past, the Slacker Obelisk, referenced in a long- 
forgotten company publication, I was stunned. Removed from the main intersection of the town before my birth and seemingly "lost" in the hillside of Lacamas Lake after some years, the oldest members of our town only vaguely remember. This memorial was a part of my community's history that someone decided should not be passed along. But it was originally placed to shape and mark the community's memory. The large obelisk erected at the main intersection of the town and directly before the mill was a resounding statement on the new moral economy. Known as the Slacker Obelisk the Crown Willamette publication Makin' Paper wrote in its October 1918 edition:

The Minute Men of Camas erected this monument on the main street of the town, and on it they have inscribed, 'Erected by the Minute Men of Camas in memory of those who refuse to support the nation that supports them.' This pillar stands not so much as a menace as an admonition and ever present reminder to those careless and selfish few whose grasping and nearsighted natures blind them to the fact that their accumulations here would disappear before the lips of Tantalus, should the Germans gain the mastery over our country. $^{2}$

This statement vindicates a self-sacrificing martial manhood in a patriotic idiom, evoking the "Minute Men" of the Revolutionary Era. The company history waxed poetic on the recent conflict in the town and celebrated a monument to the new moral economy. In this, they turned the struggles of those opposed to their views and interest into unmanly and unpatriotic foreigners (“Germans"). In other words, those who did not fight for the United States did not deserve to be remembered and experienced instead "social death." Ironically, by monumentalizing this symbolic murder, the Minute Men actually documented their foes/foils. However, the monument itself no longer exists, which makes my point about erasure. I only saw its picture one time, in a book. I called the

\footnotetext{
${ }^{2}$ Crown Willamette Paper Company, Makin’ Paper., 1918, 21.
} 
town historians and searched the physical spot where they had last seen the monument... and found nothing.

It would be not until 1964 that the city experienced significant growth and attendant strife in organized labor. The mill changed hands several times over the next few decades. Mayors, mostly Republicans, would quietly come and go. Camas continued to prosper and grow off of the benefit of the massive paper mill. Over the years, the city accumulated its own eccentric symbolism and truncated story-telling and theatricals in the story it told about itself. The local high school mascot was the Papermaker, strangely dehumanizing a human worker and turning unionism into a kind of toy or relic. The two prominent city parks, gifted to the city by Crown Willamette in 1941, were named Crown Park, after the Crown-Zellerbach Company - the owners of the mill after Crown Willamette - and Louis Block, after the chairman of the board for Crown Zellerbach, by the city council as war production went into high gear. At the dedication, 193 employees received service pins, some for as many as 40 years of service with the company. The local elementary school was named J.D. Zellerbach Elementary, gaining its name sake a prominent member of the Crown-Zellerbach Corporation, John David Zellerbach, which owned and operated the Camas mill. In this way, Crown again aligned its public face and its rewards to workers in line with patriotic war production that incidentally enriched the company. ${ }^{3}$

\footnotetext{
${ }^{3}$ Two deficiencies in information must be noted here: 1) It is most likely that one of the employees that went on strike in September 1917 was awarded a pin for service, which brings an interesting fold, but I am unable to substantiates that hypnosis at this time, and 2) The action of Crown-Zellerbach v. those of Crown Willamette were and are viewed in completely different lights by the people of Camas and sources placed shortly after the strike of 1917-1918, Roger Randall writes "Crown Willamette Paper Company was not at this time a part of the Crown-Zellerbach Corporation. The merger of the Zellerbach and Crown-Willamette interests occurred in 1928, and the management of the Crown plants at Camas and West Linn has subsequently been change" Randall, Labor Relations, 1942, 50.
} 
This thesis has argued that the company's early strategy of denial and stonewalling of unionism set an important template for the city of Camas's self-identity and the "story it told about itself." Crown was able to advance itself implicitly as a defender of local self-regulation for all by eliminating and then erasing the notion of challenges to its authority. It could enlist an ethos of "mutuality" as long as it was a hierarchical, top-down "mutuality." As long as business leaders remained in control, the story of "we care for ourselves, on our own" could be told. Any challenger had to take the position that some "we" or a "they" did not have all the answers, or was selfish, unjust, and even un-American. When women workers stepped up to tell a different story, their feistiness could be read somewhat light-heartedly, even comically. Once the menfolk were brought into line, the women were temporarily rewarded with shared police and supervisory powers - not decision-making ones. Thus the result of the early 1913 bag makers walk out was to accommodate the status quo with small "protective" adjustments to shop floor conditions. So, too, with spontaneous walkouts by men in 1916 and even in the unionizing upsurge of 1917-1918. As long as men remained essentially supplicants - despite their citizenship, voting rights, military service, and international commitment to a changed world order through socialism—Crown could deal with them by giving a little one a few issues and "protecting" the greater good, paternalistically. Once the small Socialist organization in Camas overstepped its supplicant status, with its "own" Party, "own" clubs (i.e. union locals), and it "own" (potential) police force, Crown fought back with all its might. Notably, Crown was more successful than the Socialist Party and Labor Press- even the federal government itself--in framing their critique of power sharing as a threat to the nation. They dominated the media and militarized the 
town, which isolated the Socialists and stressed their thin links to national and international supports with more pressure than they could bear. Instead of working out "protection" of women as part of their legitimation strategy, Crown went after the school board and even expelled a female teacher, under the taint of foreign subversion. In this way, the company used fear tactics in war time to cow residents into being grateful that things were not worse and to acquiesce in the belief that the company protected their safety. After all, veterans of 1898 in Camas were a visible reminder of the pain and cost of war, and the boys marching off to service in World War I likely weakened local women's and family's resolve to challenge trumped up "threats from within" when they felt afraid about enemies from "without." This is a key story that still needs deeper retelling in southwest Washington.

Historiographically, this thesis contends that like other industrial centers in the United States for a very short period of time Camas workers fought for their soul and identity. Radical-left labor and politicians were abundant in the Northwest. However, the infighting, nativist and patriotic rhetoric, and government-supported dismantling of unionism left those with radical ideals alone and discombobulated. As a result, cities like Camas all across the United States, took their politics and economies in a conservative direction, eschewing the idea of a workers' utopia, which had seemed a possibility only a few years earlier. Instead, they made uneasy peace with company paternalism and company unionism in the 1920 s. The active erasure of socialism, communism, and radical-left ideals in the Northwest and the nation in small company towns like Camas, however, still suggest the real anxiety that a potential threat from below might cause 
those at the top, as much as they wrapped themselves in the flag and in selfcongratulatory public memorials and monuments. 


\section{Bibliography}

\section{Primary Sources}

\section{Books}

Interstate Publishing Company, and Harvey Kimball Hines. An Illustrated History of the State of Washington: Containing Biographical Mention of Its Pioneers and

Prominent Citizens. Interstate Publishing Company and Lewis publishing Company, 1893.

Neuberger, Richard L. and Kelley Loe. An Arm of the Aged a History and Analysis of the Townsend Old Age Pension Plan. First Edition. The Caxton Printers, Ltd, Caldwell, ID, 1936.

\section{National, City, and Local Directories}

Ayer Directory of Publications. Ayer Press, 1908.

Jackson, Jay M. Real Estate Directory 1912-1913: A Directory of the Leading Real Estate Agents, Abstractees, Loan Companies and Real Estate Attorneys of the United States and Canada, 1912.

“Polk Directory - Vancouver and Vicinity.” Seattle, WA: R.L. Polk and Company, 1912.

"Polk Directory - Vancouver and Vicinity." Seattle, WA: R.L. Polk and Company, 1914.

“Polk Directory - Vancouver and Vicinity.” Seattle, WA: R.L. Polk and Company, 1916.

“Polk Directory - Vancouver and Vicinity.” Seattle, WA: R.L. Polk and Company, 1919.

\section{Government Reports, Documents, Publications, and Minutes}

Camas City Council Records. Camas, WA, 1917-1917.

Missouri Secretary of State. Official Manual of the State of Missouri. Office of the Secretary of State for Missouri, 1901.

Smith, W.R., and National War Labor Board. "In the Matter of the Strike of the International Brotherhood of Paper Makers, the International Brotherhood of Pulp Sulphite and Paper Mill Workers and the International Association of Machinists. In the Mills of the Crown-Willamette Paper Company at Camas Washington Oregon City and Lebanon Oregon and the Hawley Pulp and Paper Company at Oregon City Oregon.” Washington D.C.: National War Labor Board, August 3, 1918. 
(State), Washington. Washington Public Documents, 1908.

(State), Washington, and Sam H Nichols. Session Laws of the State of Washington Seventh Session 1901. Olympia, WA: Washington State Secretary of State, 1901.

Wilson, William B. "Report of President Wilson's Mediation Commission.” Portland, OR: National War Labor Board, April 1918.

"Year: 1910; Census Place: Columbia, Clark, Washington; Roll: T624_1655; Page: 8A; Enumeration District: 0058; FHL Microfilm: 1375668." Ancestry.com, n.d.

"Year: 1920; Census Place: Camas, Clark, Washington; Roll: T625_1921; Page: 1A-20B; Enumeration District: 9; Image: 1032-1071," n.d.

\section{Journals and Articles}

American Trade Index. National Association of Manufacturers. 1913.

Bing, Alexander M. "The Work of the Wage-Adjustment Boards." Journal of Political Economy 27, no. 6 (June 1, 1919): 421-56.

Crown Willamette Paper Company. “Makin' Paper.” Makin' Paper. 1, no. 4 (October 1918).

Garment Worker: Official Organ of the United Garment Workers of America. 1st ed. Vol. 17. New York, NY: United Garment Workers of America, 1917.

Monthly Labor Review. Vol. 14. 1 vols. Bureau of Labor Statistics, 1924.

Municipal Journal and Engineer. Municipal Journal and Engineer, Incorporated, 1908.

Paper: A Weekly Technical Journal for Paper and Pulp Mills, 1918.

The Paper and Pulp Makers' Journal. Vol. Vo. 16. No. 1 vols. Albany, NY: International Brotherhood of Paper and Pulp Makers, 1917.

The Paper and Pulp Makers' Journal. Vol. Vol. 16. No. 11 vols. International Brotherhood of Paper and Pulp Makers, 1917.

The Paper and Pulp Makers' Journal. Vol. Vol 17. No 5 vols. Albany, NY: International Brotherhood of Paper and Pulp Makers, 1918.

The Paper Makers Journal. International Brotherhood of Paper Makers, 1912. 
The Paper Makers Journal. Vol. June 1916. International Brotherhood of Paper Makers, 1915.

The Paper Makers Journal. Vol. July 1916. International Brotherhood of Paper Makers, 1915.

The Paper Makers Journal. Vol. Vol 16. No 8 vols. International Brotherhood of Paper Makers, 1917.

The Paper Makers Journal. Vol. Vol 17. No 1 vols. International Brotherhood of Paper Makers, 1917.

The Paper Makers Journal. International Brotherhood of Paper Makers, 1918.

The Paper Makers Journal. International Brotherhood of Paper Makers, 1921.

Typographical Journal. International Typographical Union. 1918.

\section{Legal Cases}

State of Washington v. Frank Frampton. Case 1232. (Clark County Superior Court 1918).

State of Washington v. George Beetsch. Case 1217. (Clark County Superior Court 1918).

State of Washington v. Meta Frampton. Case 1255 (Clark County Superior Court 1918).

\section{Newspapers}

“\$13,000,000 Paper Merger Organized.” The Oregonian. October 2, 1914.

“75 Paper Mill Men Quit.” The Oregonian. April 17, 1917.

“200 Knights Meet at Camas.” The Oregonian. April 27, 1910.

“542 Men Working in Camas Paper Plant.” The Camas Post. December 7, 1917.

“1200 Paper Mill Men Go Out on Strike.” The Oregonian. October 26, 1917.

“Agree to Arbitrate Their Differences.” The Camas Post. May 19, 1916.

“Alleged Slacker Inducted.” The Oregonian. October 6, 1918.

“Alleged That Beech Was Roughly Used.” The Camas Post. November 16, 1917.

“Amount of Business Light for Council.” The Morning Oregonian. January 1, 1918. 
“Annual Rest Day Is Enjoyed Highly.” The Oregonian. September 4, 1917.

“Another Legal Farce.” Oregon Labor Press. March 9, 1918.

“A Real Labor Leader." The Oregonian. September 6, 1957.

“Are American Workers Patriotic.” Oregon Labor Press. November 3, 1917.

“Bag Factory Is Swamped.” The Oregonian. September 28, 1913.

“Benefit Dance for Paper Mill Strike.” Oregon Labor Press. December 29, 1917.

“Big Factory Strike Ends.” The Morning Oregonian. February 13, 1913.

"Boddy’s Rejoinder to Garrett.” The Commonwealth. March 28, 1913.

"British Columbia." Pullman Herald. March 21, 1903.

"Business District of Camas Flooded.” The Vancouver Columbian. January 30, 1913.

“Camas." The Olympia Daily Recorder. February 5, 1909.

“Camas Business Men Investigate Strike.” The Camas Post. November 23, 1917.

“Camas Council Appoints W.E. Farr to Office.” The Oregonian. March 14, 1918.

“Camas Council at Peace.” The Oregonian. January 14, 1917.

“Camas Factory Girls Strike.” The Morning Oregonian. January 24, 1913.

“Camas Labor Celebrates." The Oregonian. September 9, 1917.

“Camas Mill Closes Down.” The Oregonian. April 18, 1917.

“Camas Paper Mill Big.” The Oregonian. June 29, 1913.

“Camas Paper Mill Improved.” The Oregonian. January 28, 1915.

"Camas Payroll Is Big." The Oregonian. October 6, 1913.

"Camas People Were One on Labor Day." The Camas Post. September 8, 1917.

"Camas Recall Filed.” The Oregonian. January 21, 1918.

"Camas Sets Heel on Seditions Head." The Oregonian. March 11, 1918. 
"Camas Socialist Elect Mayor." The Oregonian. December 8, 1916.

"Camas Strike Continues." The Oregonian. November 27, 1917.

“Camas Strikers Reply.” The Oregonian. November 14, 1917.

"Camas Woman Convicted." The Oregonian. February 23, 1918.

"Camas Workers Attacked." The Oregonian. December 4, 1917.

"Carl Ulonska.” The Northwest Worker. May 19, 1917.

"City Is to Frolic with Labor Today." The Oregonian. September 3, 1917.

“Clean up Campaign Over.” The Oregonian. March 14, 1918.

"Council in a Long Continuous Session." The Camas Post. December 15, 1916.

“Councilman Farrell Presided at Meeting.” The Camas Post. January 1, 1918.

“Council Session Was on Order of Brevity.” The Camas Post. December 14, 1917.

“Crown-Willamette Paper Mill Workers Strike.” Oregon Labor Press. October 27, 1917.

“Death Takes Kelley Loe.” The Oregonian. September 5, 1957.

"Deputies Held Ready.” The Oregonian. April 16, 1917.

"Discussed Matter of Street Vacation." The Camas Post. February 8, 1918.

“Disloyal Teacher Quits.” The Oregonian. February 13, 1918.

“Dynamite Sold Under License.” The Camas Post. November 23, 1917.

“Encouraging News From Camas Strike.” Oregon Labor Press. December 29, 1917.

“Editorial.” The Morning Oregonian. December 28, 1917.

“Encouraging News from Camas Strike.” Oregon Labor Press. December 29, 1917.

"Enemy Alien Rules for German Women." The Camas Post. January 18, 1918.

"Enthusiastic Mass Meeting at Camas.” Oregon Labor Press. December 29, 1917. 
“Five Machines Now Turning Out Paper.” The Camas Post. November 30, 1917.

"Flag Raised at Camas." The Oregonian. April 8, 1917.

"Free Speech and Capitalism." The Commonwealth. October 10, 1913.

"Germans Design to Crush America." The Camas Post. February 15, 1918.

"Girls Continue Strike at Camas Paper Bag Plant." The Vancouver Columbian. February 13, 1913.

“Girls Win Strike.” Daily Capital Journal. February 12, 1913.

"Godwin at Camas." The Oregonian. March 3, 1918.

"Godwin Goes to Camps." The Oregonian. October 4, 1917.

“Grange Resolution Is Against Strikes.” The Camas Post. November 23, 1917.

"Had Skirmish with I.W.W.” The Camas Post. November 23, 1917.

“Hawley’s to Start.” The Oregonian. October 27, 1917.

Herman, Emil. "Right of Free Speech Denied the Workers." The Northwest Worker. August 12, 1915.

"Insure Your Future.” The Oregonian. January 1, 1909.

"Is Business Rotten in City of Camas?" The Camas Post. February 1, 1918.

“Jensen Says He Is a Stars and Stripes Socialist.” The Bellingham Herald. March 6, 1913.

“Joseph S. McAllister.” The Oregonian. December 30, 1938.

Kelley, Loe. "Labor Ponders Possibility of Own Third Party." The Oregonian. September 13, 1936.

__. "The Negative Argument." The Oregonian. January 5, 1936.

“Labor Day Plans Making.” The Oregonian. August 4, 1917.

"Laborers Far in Excess of Demand." The Morning Oregonian. December 21, 1917.

"Larceny Charge Holds at Camas." The Oregonian. June 30, 1912. 
“Laundry Girls out on Strike.” Spokane Daily Chronicle. April 27, 1911.

“Laundry Girls Strike.” Bellingham Herald. April 27, 1911.

"Lebanon Mill Men Strike.” The Oregonian. November 2, 1917.

“Lebanon Workers Are Standing Firm.” Oregon Labor Press. November 17, 1917.

"Lectures Held Next Week." The Northwest Worker. August 19, 1915, No. 241 edition.

"Letters Indicate Truth of Charges." The Camas Post. May 24, 1918.

"Lewthwaite Rites Set.” The Oregonian. January 25, 1932.

“Local Mill Now Has One Machine Running.” The Camas Post. November 16, 1917.

"Local Unions Offer a Plain Statement." The Camas Post. November 9, 1917.

"Loyal Comrades." The Commonwealth. October 23, 1913.

“Mass Meetings Are Held in Oregon City.” Oregon Labor Press. November 24, 1917.

“Mayor Clark Fires Finance Committee.” The Camas Post. November 9, 1917.

"Mayor of Camas Resigns." The Morning Oregonian. February 26, 1913.

"Mayor Touches off First Campaign Gun.” The Camas Post. February 15, 1918.

"Mediation Commission Visits the City." Oregon Labor Press. December 1917.

"Mediator Rolled in Mud." The Morning Oregonian. February 5, 1913.

"Mill Companies Circulate Rumors Strike Is Off." Oregon Labor Press. December 29, 1917.

“Mill Company Starts Machine Next Week." The Camas Post. November 9, 1917.

"Montana Asks for Troops, If Needed. Governor Makes Request of President, Fearing 500 Militiamen Too Few.” The Oregonian. June 16, 1911.

"New Plant to Be Ready January." The Oregonian. August 3, 1913.

"New Trial Asked." The Oregonian. March 13, 1918.

"No Prospects for Mediation.” The Camas Post. December 7, 1917. 
"Not All of Men Quit." The Oregonian. October 27, 1917.

“Oregon City Millman Declares His Opinion.” The Camas Post. November 30, 1917.

“Oregon City Sees Donnybrook Fair.” The Oregonian. June 23, 1918.

“Other Views on Haywood.” The Spokane Press. August 2, 1907.

"Pacifists with German Names." The Oregonian. March 20, 1917.

"Paper Machine Is Largest in World." The Morning Oregonian. April 14, 1912.

"Paper Makers Put Differences Up to Mediation Board." Oregon Labor Press. December 1917.

“Paper Makers Walk Out at Camas Mill.” Bellingham Herald. May 13, 1916.

“Paper Mill Hands Strike.” The Morning Oregonian. May 3, 1916.

“Paper Mill Pay Roll Is Close to Normal.” The Camas Post. December 14, 1917.

“Paper Mill Strike Spreads to Lebanon.” Oregon Labor Press. November 10, 1917.

“Paper Mills Will Not Employ Union Labor.” The Camas Post. November 23, 1917.

"Paper Mill Work at Camas, Washington.” The Oroville Weekly Gazette. April 19, 1918.

“Paper Mill Workers Ask for Fair Deal.” Oregon Labor Press. December 1917.

“Paper Mill Workers at Camas Hold the Fort.” Oregon Labor Press. November 17, 1917.

“Paper Mill Workers Hold Mass Meeting.” Oregon Labor Press. November 10, 1917.

“Paper Mill Workers Hold Mass Meeting.” Oregon Labor Press. November 17, 1917.

"Paper Mill Workers Walk Out on Strike.” The Camas Post. November 2, 1917.

"Peace Slogan Ridiculed.” The Oregonian. October 30, 1916.

"Peonage and the Palouse." The Commonwealth. October 2, 1913.

"Philbrick Is Named as Council Member." The Camas Post. February 15, 1918.

“Post Details Facts Not Printer Before.” The Morning Oregonian. December 21, 1917. 
"President's Mediation Commission Score 'Open Shop' Policy of Paper Mill Managers." Oregon Labor Press. December 22, 1917.

“Pythians Will Convene.” The Oregonian. March 27, 1916.

“Recall Is Invoked by Camas Electors." The Camas Post. January 18, 1918.

“Recall to Be Attempted." The Oregonian. November 19, 1917.

"Remember Donald McMaster Speech at Opera House Tonight." The Camas Post. November 3, 1916.

“Report of Unions.” The Labor Journal. December 7, 1917.

“Republicans Sweep Clarke.” The Oregonian. November 9, 1916.

"Ridgefield to Have Newspaper.” The Oregonian. September 11, 1909.

"Scabs Being Injured in the Paper Mills." Oregon Labor Press. December 15, 1917.

"Secretary of Labor to Visit Portland." Oregon Labor Press. November 24, 1917.

"Seeking to Put One Over on Third Ward." The Camas Post. February 1, 1918.

“Sewer Proposition Rejected in Council." The Camas Post. November 30, 1917.

“Sheriff Biesecker Takes Firm Stand.” The Morning Oregonian. December 28, 1917.

"Sheriff Drops Down Upon the Picket Line.” The Camas Post. May 24, 1918.

“Sheriff of Clarke County Seeks Re-Election.” The Oregonian. May 29, 1916.

"Sheriff Organizes Staff." The Oregonian. April 14, 1917.

“Sheriff’s Duties Are Many and Exacting." The Morning Oregonian. December 21, 1917.

“Sheriffs Will Convene.” The Oregonian. May 23, 1918.

“Six Girl Strikers Put Under Arrest.” The Camas Post. November 30, 1917.

“Smith Speaker at Mass Meeting.” The Camas Post. November 30, 1917.

“Socialist Mayor Is Elected in Camas.” The Camas Post. December 8, 1916. 
“Socialist Mayor Is In.” The Oregonian. January 11, 1917.

"Strike at Camas Is Settled." The Vancouver Columbian. February 13, 1913.

“Strike at Camas Is Settled.” The Oregonian. April 22, 1917.

"Strikebreakers Are Brought to Oregon City Mills." Oregon Labor Press. November 17, 1917.

“Strike Called Off." Oregon Labor Press. September 19, 1918.

“Strike Nearly Ended.” The Oregonian. November 20, 1917.

"Strike of Employes of the Willamette Paper Company." The Labor Journal. November 2,1917

"Strikers Are Foiled." The Oregonian. March 30, 1916.

"Strikers at Camas Are Holding Firm.” Oregon Labor Press. December 15, 1917.

"Strikers Get Justice in Mediation Report." Oregon Labor Press. December 29, 1917.

“Strike Situation at Lebanon Mill.” Oregon Labor Press. November 24, 1917.

"Strike Situation at Oregon City and Camas." Oregon Labor Press. November 10, 1917.

"Strike Situation in Camas Paper Mill." Oregon Labor Press. November 24, 1917.

—. Oregon Labor Press. January 26, 1918.

—. Oregon Labor Press. March 23, 1918.

_. Oregon Labor Press. April 13, 1918.

—. Oregon Labor Press. April 20, 1918.

—. Oregon Labor Press. April 27, 1918.

—. Oregon Labor Press. May 25, 1918.

“Strike Workmen in Open Mass Meeting.” The Camas Post. November 16, 1917.

“Struggle Will Be a Hard One.” The Commonwealth. February 19, 1914. 
“Teacher Is Charged with Seditious Talk.” The Camas Post. February 15, 1918.

The Commonwealth, October 23, 1913.

"The Manhood in the Pit." The Seattle Star. August 6, 1912.

“The Mayor’s Touch.” The Oregonian. January 6, 1910.

“The Socialists Draw Record Attendance.” The Camas Post. October 27, 1916.

“The Strike at Camas.” Oregon Labor Press. December 1917.

“The Strike Breakers.” Oregon Labor Press. November 24, 1917.

"This Paper Was Manufactured for the Oregonian by the Crown-Columbia Pulp and Paper Co." The Oregonian. February 11, 1911.

“Tuesday Session.” The Labor Journal. December 7, 1917.

"Vancouver Is Picked." The Oregonian. December 9, 1917.

"Vancouver Listing Men Who Signed." The Oregonian. June 16, 1917.

"Vanlear Speaks to Big Audience." The Labor Journal. March 3, 1911.

"Wandered Back to Camas." The Camas Post. December 7, 1917.

Wanhope, John G. "The Slaves of Camas Mill.” The Commonwealth. February 27, 1913.

"Washington Brieflets." Lynden Tribune. February 20, 1913.

"Wash. Notes." The Northwest Worker. May 3, 1917.

"Was It Insulting of the A.F. Of L?" The Commonwealth. September 18, 1913.

"What One Plant Did." The Labor Journal. April 11, 1913.

“Why Not Settle It?” Oregon Labor Press. December 8, 1917.

Williams, George. "Height of Idiocy.” The Oregonian. February 9, 1915.

“W. Lewthwaite Is Dead.” The Oregonian. January 3, 1909.

“Woman Declared Pro-Hun.” The Oregonian. May 26, 1918. 
"Would Cut Out Sweatbands." The Camas Post. November 23, 1917.

The Seattle Star. July 8, 1913.

The Tacoma Times. February 5, 1914.

The Washington Socialist, November 12, 1914.

The Camas Post. February 8, 1918.

\section{Organizational Reports and Minutes}

Camas Commercial Club Records. Camas, WA, 1917-1918.

Gompers, Samuel. The American Federationist. Vol. 25. American Federation of Labor and Congress of Industrial Organizations, 1918.

Labor, American Federation of, and American Federation of Labor Convention. Report of Proceedings of the Annual Convention of the American Federation of Labor.

American Federation of Labor. 1917.

\section{Websites}

“1912 Presidential Election.” Accessed June 14, 2015. http://www.presidency.ucsb.edu/showelection.php? year=1912.

"Election Results Search.” Accessed May 13, 2015.

http://www.sos.wa.gov/elections/results_search.aspx.

"Voters' Pamphlet 1914.pdf." Accessed Ma 13, 2015. http://www.sos.wa.gov/ assets/elections/Voters\%27\%20Pamphlet\%201914.pdf.

“Voters' Pamphlet 1916.pdf." Accessed May 13, 2015. http://www.sos.wa.gov/ assets/elections/Voters\%27\%20Pamphlet\%201916.pdf.

"Voters' Pamphlet 1918.pdf." Accessed May 13, 2015. http://www.sos.wa.gov/_assets/elections/Voters\%27\%20Pamphlet\%201918.pdf.

\section{Secondary Sources}

2009, -January 1. The Good Times Are All Gone Now: Life, Death, and Rebirth in an Idaho Mining Town [Paperback] [2009] (Author) Julie Whitesel Weston. University of Oklahoma Press, 2009.

Adams, W. Claude. "History of Papermaking in the Pacific Northwest: I." Oregon Historical Quarterly 52, no. 1 (March 1, 1951): 21-37. 
Alice. Kessler-Harris. In Pursuit of Equity Women, Men, and the Quest for Economic Citizenship in 20th-Century America. New York: Oxford University Press, 2001.

Out to Work: A History of Wage-Earning Women in the United States. New York: Oxford University Press, 1982.

Amsterdam, Susan. “The National Women's Trade Union League.” The Social Service Review, 1982, 259-72.

Annelise. Orleck. Common Sense \& a Little Fire: Women and Working-Class Politics in the United States, 1900-1965. Gender \& American Culture. Chapel Hill: University of North Carolina Press, 1995.

Archer, Robin. Why Is There No Labor Party in the United States?. Princeton: Princeton University Press, 2007.

Argersinger, Jo Ann E. The Triangle Fire : A Brief History with Documents. Bedford Series in History and Culture. Boston: Bedford/st Martins, 2009.

Arnesen, Eric, Julie Greene, and Bruce Laurie, eds. Labor Histories: Class, Politics, and the Working-Class Experience. Urbana: University of Illinois Press, 1998.

Arsdol, Ted Van. Vancouver On The Columbia - An Illustrated History. Windsor Publications, Inc, 1986.

Barbara, Labor Relief Association, Santa, and Rowland Hazard. Labor Relief: The Tramp Question Practically Solved in This City. An Association Is Formed Which Adopts a Model Plan for Dealing with the Unemployed. - Work for All, 1895.

Benton-Cohen, Katherine. Borderline Americans: Racial Division and Labor War in the Arizona Borderlands. Cambridge, Mass.: Harvard University Press, 2011.

Bois, William Edward Burghardt Du, and Isabel Eaton. The Philadelphia Negro: A Social Study. University of Philadelphia, 1899.

“Center for Columbia River History - Camas.” Accessed July 2, 2015. http://www.ccrh.org/comm/camas/index.php.

Copeland, Tom. The Centralia Tragedy of 1919: Elmer Smith and the Wobblies. Seattle: University of Washington Press, 1993.

Dembo, Jonathan. An Historical Bibliography of Washington State Labor and Laboring Classes. Pacific Northwest Labor History Association, 1978. 
Dick, William M. Labor and Socialism in America; the Gompers Era. Port Washington, N.Y.: Kennikat Press, 1972.

Dilg, Janice. "By Proceeding in an Orderly and Lawful Manner: Protective Legislation, Working Women, and Progressive Politics 1913-1924." Oregon Historical Quarterly Vol. 110 no. 1 (2005): 96-129.

Forbath, William E. Law and the Shaping of the American Labor Movement. Cambridge, Mass.: Harvard University Press, 1991.

Fort Vancouver Historical Society. Clark County History. Fort Vancouver Historical Society ; v. 25. Vancouver, Wash: Fort Vancouver Historical Society of Clark County, 1984.

- Clark County History. Fort Vancouver Historical Society; v. 28. Vancouver, Wash: Fort Vancouver Historical Society of Clark County, 1987.

- Clark County History. Fort Vancouver Historical Society ; v. 29. Vancouver, Wash: Fort Vancouver Historical Society of Clark County, 1988.

- Clark County History. Fort Vancouver Historical Society ; v. 34. Vancouver, Wash: Fort Vancouver Historical Society of Clark County, 1993.

Frank, Dana. Purchasing Power: Consumer Organizing, Gender, and the Seattle Labor Movement, 1919-1929. Cambridge England; New York: Cambridge University Press, 1994.

Goldberg, Joseph P, and William T Moye. "The First Hundred Years of the Bureau of Labor Statistics.” U.S. Department of Labor Bulletin 2235 (September 1985).

Graham, Harry E. The Paper Rebellion: Development and Upheaval in Pulp and Paper Unionism. Iowa City, University of Iowa Press, 1970.

Guglielmo, Jennifer. “Transnational Feminism's Radical Past: Lessons from Italian Immigrant Women Anarchists in Industrializing America. (Report)." Journal of Women's History 22, no. 1 (2010): 10.

Heather N. Pool. Political Mourning. Thesis PhD--University of Washington, 2011.

Helmbold, Lois Rita, and Ann M. Schofield. “Women's Labor History,” 1989. https://kuscholarworks.ku.edu/handle/1808/17045.

"History | Bread and Roses Centennial." Accessed June 14, 2015. http://breadandrosescentennial.org/node/77. 
Kathryn Kish. Sklar. Florence Kelley and the Nation's Work. New Haven: Yale University Press, 1995.

“Labor History Encyclopedia." Accessed July 3, 2015. http://depts.washington.edu/labhist/encyclopedia/browse.shtml.

"Let Me Say This About That.” Accessed July 2, 2015. http://nwlaborpress.org/klare/110201.html.

"National Statistics 'Sunday Work' in the Early 20th Century - Google Search." Accessed June 21, 2015. https://www.google.com/search? q=national+statistics + on + sunday + work + in + the + ear $1 \mathrm{y}+20$ th + century\&ie $=$ utf- $8 \&$ oe $=$ utf8\#newwindow $=1 \& q=$ national + statistics $+\% 22$ sunday + work $\% 22+$ in + the + early +20 th tcentury.

"Open Collections Program: Women Working, Lawrence Strike of 1912." Accessed June 14, 2015. http://ocp.hul.harvard.edu/ww/lawrencestrike.html.

Orren, Karen. Belated Feudalism: Labor, the Law, and Liberal Development in the United States. Cambridge [England]; New York: Cambridge University Press, 1991.

Putman, John C. Class and Gender Politics in Progressive-Era Seattle. Urban West. Reno: University of Nevada Press, 2008.

Randall, Roger Lewis, United States. Bonneville Power Administration and Pacific Northwest Regional Planning Commission. Labor Relations in the Pulp and Paper Industry of the Pacific Northwest. Portland, Or: Northwest regional council in cooperation with the Bonneville power administration, the Pacific Northwest regional planning commission. 1942.

Raymond, F.E.H. “The Tramp Question.” Frank Leslie's Popular Monthly, 1888.

Redinger, Angela. "Early Camas History.” Accessed July 2, 2014. http://www.ccrh.org/comm/camas/student\%20papers/camas\%20paper.htm.

Reimer, Kimberley. "Seattle General Strike: Laundry Workers." Seattle General Strike Project. Accessed April 6, 2015. http://depts.washington.edu/labhist/strike/reimer.shtml.

Robert D. Johnston. The Radical Middle Class Populist Democracy and the Question of Capitalism in Progressive Era Portland, Oregon. Politics and Society in TwentiethCentury America. Princeton: Princeton University Press, 2013. 
Ross, Jack. The Socialist Party of America: A Complete History. U of Nebraska Press, 2015.

Ross, William G. A Muted Fury: Populists, Progressives, and Labor Unions Confront the Courts, 1890-1937. Princeton, N.J.: Princeton University Press, 1994.

Schwantes, Carlos Arnaldo. Radical Heritage: Labor, Socialism, and Reform in Washington and British Columbia, 1885-1917. Moscow, Idaho: Caxton Press, 1994.

“Seattle General Strike.” Accessed June 26, 2015. https://depts.washington.edu/labhist/strike/gold.shtml.

Stanton, Theodore. The Woman Question in Europe: A Series of Original Essays. G. P. Putnam's sons, 1884.

Steinberg, Ronnie J. Wages and Hours : Labor and Reform in Twentieth-Century America. Crime, Law, and Deviance Series. New Brunswick, NJ: Rutgers University Press, 1982.

Stevenson, Shanna. "The Fight for Washington Women's Suffrage: A Brief History." Washington State Historical Society, n.d. http://www.washingtonhistory.org/files/library/TheFightforWashingtonWomensSuff rageABriefHistory.pdf.

Thompson, Edward P. "The Moral Economy of the English Crowd in the Eighteenth Century." Past and Present, 1971, 76-136.

Tomlins, Christopher L. The State and the Unions: Labor Relations, Law, and the Organized Labor Movement in America, 1880-1960. Cambridge; New York: Cambridge University Press, 1985.

Van Arsdol, Ted. "Camas Early Days." Fort Vancouver Historical Society Annual Publication VIII (1967).

Watson, Bruce. Bread and Roses : Mills, Migrants, and the Struggle for the American Dream. New York, NY: Penguin Books, 2006.

William Cahn. Lawrence, 1912 : The Bread and Roses Strike. New York: Pilgrim Press, 1980.

William D. Welsh. A Brief History of Camas, Washington. 8th printing. Camas, Wash: Camas Division of Crown Zellerbach Corp, 1956.

Woloch, Nancy. Muller v. Oregon : A Brief History with Documents. Bedford Series in History and Culture. Boston: Bedford Books of St. Martin's Press, 1996. 
Zieger, Robert H. Rebuilding the Pulp and Paper Workers' Union, 1933-1941. Knoxville: University of Tennessee Press, 1984. 